INL/EXT-17-43199

\title{
RELAP-7 Software Verification and Validation Plan
}

\section{Requirements Traceability Matrix (RTM) Update and Code Verification Strategy}

\author{
Junsoo Yoo \\ Yong-Joon Choi
}

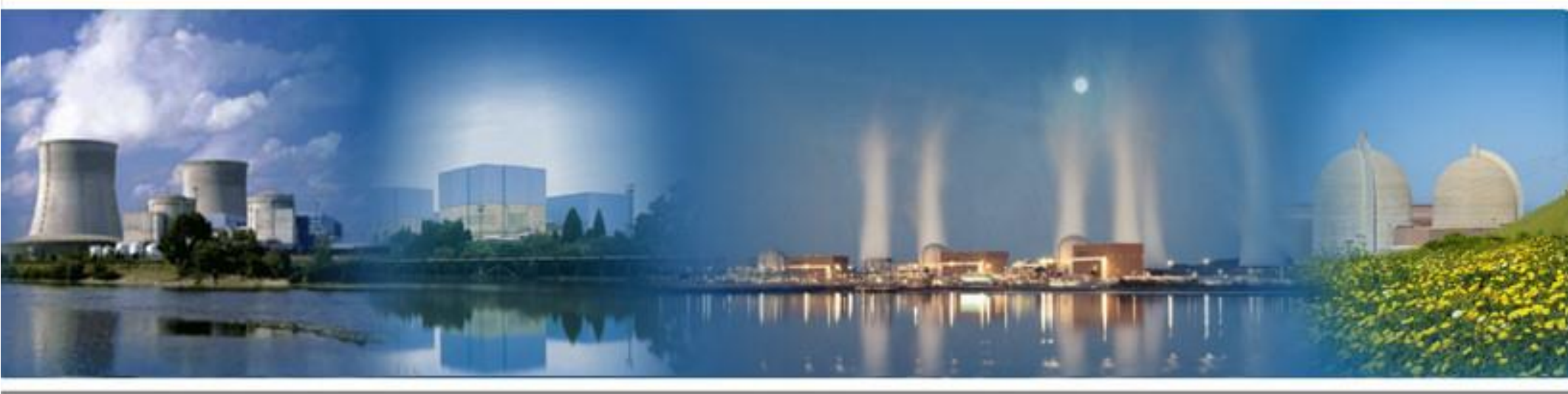

September 2017

DOE Office of Nuclear Energy 


\section{NOTICE}

This report was prepared as an account of work sponsored by an agency of the United States Government. Neither the United States Government nor any agency thereof, nor any of their employees, makes any warranty, express or implied, or assumes any legal liability or responsibility for any third party's use, or the results of such use, of any information, apparatus, product, or process disclosed in this report, or represents that its use by such third party would not infringe privately owned rights. 


\title{
RELAP-7 Software Verification and Validation Plan \\ Requirements Traceability Matrix (RTM) Update and Code Verification Strategy
}

\author{
Junsoo Yoo \\ Yong-Joon Choi
}

September 2017

Idaho National Laboratory

Idaho Falls, Idaho 83415 



\begin{abstract}
This document describes the recent progress of the RELAP-7 Software Verification and Validation Plan (SVVP). The RELAP-7 RTM has been updated by adding the validation requirement items, rearranging the requirement items, and introducing the classifier to better describe the RELAP-7 V\&V status at a specified point in time. Also, from the perspective of nuclear system code validation, six items from the list of LWR safety-relevant phenomena were identified as validation data gaps. Lastly, motivated by the needs revealed from the previous RELAP-7 IV\&V activities, the independent verification plan for RELAP-7 has been established. The verification method, procedure, and verification test coverage suite discussed in this document will be applied to the future work for the RELAP-7 independent verification.
\end{abstract}


RELAP-7 Software Verification and Validation Plan: Requirements Traceability Matrix (RTM) Update and Code Verification Strategy

\section{PREFACE}

\section{Document Version}

This document is released as Revision 0 .

It is the reader's responsibility to ensure he/she has the latest version of this document. Direct Questions may be directed to the owner of the document and project manager:

Project Manager: Curtis L. Smith, RISMC Pathway Lead

Idaho National Laboratory

Phone: (208) 526-9804.

E-mail: Curtis.Smith@inl.gov . 
RELAP-7 Software Verification and Validation Plan: Requirements Traceability Matrix (RTM) Update and Code Verification Strategy 
RELAP-7 Software Verification and Validation Plan: Requirements Traceability Matrix (RTM) Update and Code Verification Strategy

\section{CONTENTS}

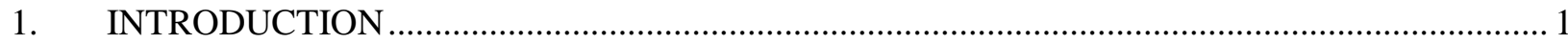

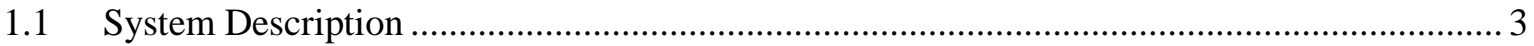

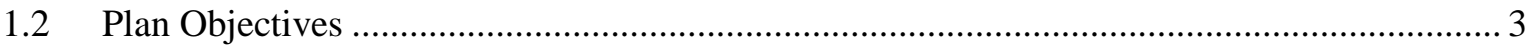

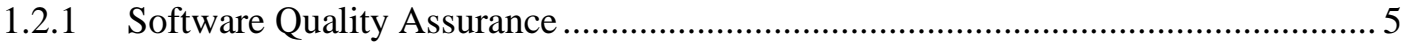

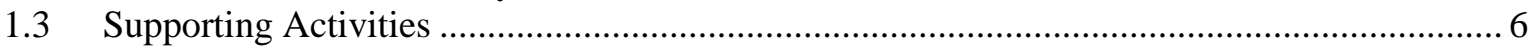

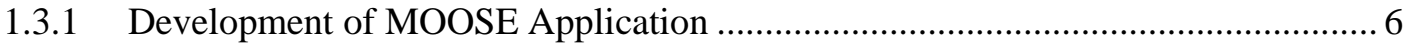

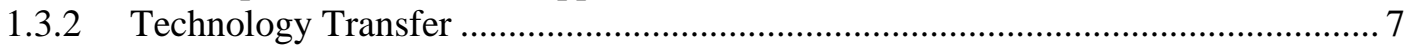

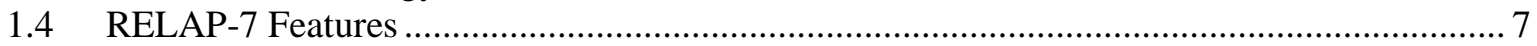



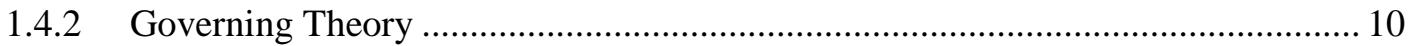



2. RELAP-7 INDEPENDANT VERIFICATION AND VALIDATION PLAN ............................... 12

2.1 RELAP-7 Code Assessment Plan and RTM Establishment [3] ......................................... 12

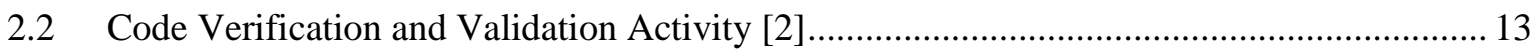

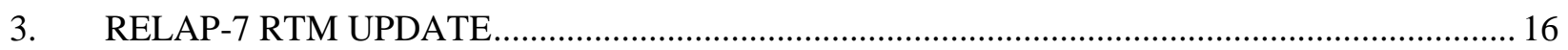

4. EVALUATION MATRIX FOR RELAP-7 RTM AND VALIDATION DATA GAP.................... 18

5. RELAP-7 VERIFICATION STRATEGY, PROCEDURE, AND VERIFICATION TEST

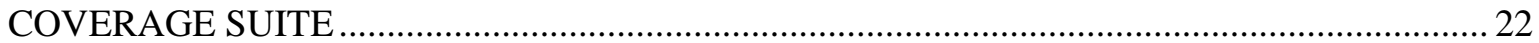

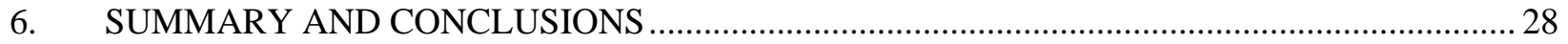



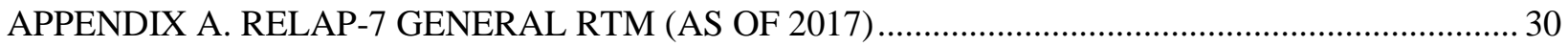

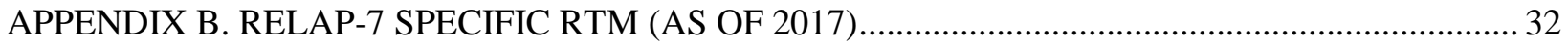

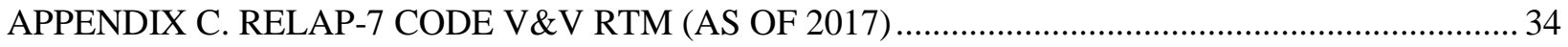


RELAP-7 Software Verification and Validation Plan: Requirements Traceability Matrix (RTM) Update and Code Verification Strategy

\section{FIGURES}

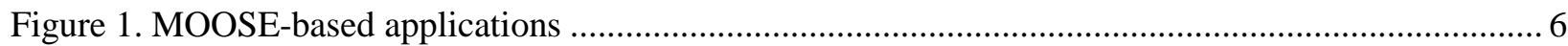

Figure 2. Characterization of requirements for RELAP-7 RTM (as of 2017) ....................................... 13

Figure 3. RELAP-7 test setup for void fraction advection problem (top) and test result (bottom) [2]....... 14

Figure 4. RELAP-7 test setup for phase-separation problem (top) and test result (bottom) [2] ................ 15

Figure 5. Conceptual schematic for RELAP-7 code verification and validation ..................................... 22

Figure 6. Independent code verification procedure for RELAP-7 ..................................................... 24

Figure 7. Three refinement strategies for the order-verifictaion test .................................................. 25

Figure 8. Order-of-accuracy test result for Task No. 1 using RELAP-7 …............................................ 27

\section{Tables}

Table 1. RELAP-7 assessment workscope/plan according to the progress of RELAP-7 development ....... 2

Table 2. Component-related attributes for the RELAP-7 (as of 2017) ................................................. 9

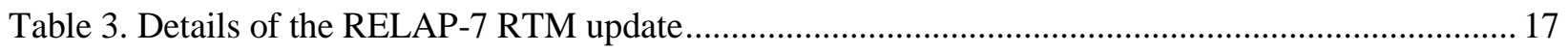

Table 4. Evaluation matrix for fundamental tests (FT, VR-18 VR-54) in RELAP-7 code V\&V RTM.... 20

Table 5. Evaluation matrix for separate effect tests (SET, VR-55 VR-77) in

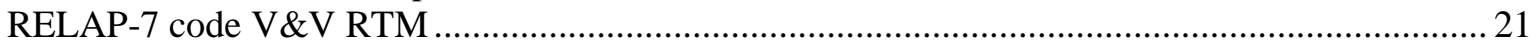

Table 6. RELAP-7 verification test coverage suite for flow problems (pipe component)....................... 26 


\section{ACRONYMS}

$\begin{array}{ll}\text { CT } & \text { Component Test } \\ \text { DOE } & \text { Department of Energy } \\ \text { EOS } & \text { Equation of State } \\ \text { FT } & \text { Fundamental Test } \\ \text { IET } & \text { Integral Effect Test } \\ \text { INL } & \text { Idaho National Laboratory } \\ \text { IV\&V } & \text { Independent Verification and Validation } \\ \text { LWR } & \text { Light Water Reactor } \\ \text { LWRS } & \text { Light Water Reactor Sustainability } \\ \text { MOOSE } & \text { Multi-Physics Object Oriented Simulation Environment } \\ \text { RTM } & \text { Requirements Traceability Matrix } \\ \text { SET } & \text { Separate Effect Test } \\ \text { SVVP } & \text { Software Verification and Validation Plan } \\ \text { V\&V } & \text { Verification and Validation }\end{array}$


RELAP-7 Software Verification and Validation Plan: Requirements Traceability Matrix (RTM) Update and Code Verification Strategy 


\title{
RELAP-7 Software Verification and Validation Plan
}

\author{
Requirements Traceability Matrix (RTM) Update and Code \\ Verification Strategy
}

\section{INTRODUCTION}

RELAP-7 is a next generation nuclear reactor system analysis code that has been developed by Idaho National Laboratory (INL). The RELAP-7 development has been supported by the LWRS program of DOE, which aims to provide an advanced analysis tool that can be applied to the Risk-Informed Safety Margins Characterization (RISMC) methodology and to support the nuclear power plant safety analysis. The development of system safety analysis code, such as RELAP-7, generally involves four sequential phases: (i) Phase I - prototype code, (ii) Phase II - demonstration code, (iii) Phase III - production code, and (iv) Phase IV - licensing code. As of FY-17, the development status of RELAP-7 is in Phase II [1].

Besides the development effort for RELAP-7, INL has also launched a "RELAP-7 Software Verification and Validation Plan (SVVP)." The primary goal of RELAP-7 SVVP is to identify all the requirements for RELAP-7, such as software design requirements, V\&V test matrix, and measureable metric matrix that can quantify the code assessment activities (i.e., RTM), etc., and to establish the RELAP-7 assessment plan. If needed, the RELAP-7 development status can also be assessed with the test problems designated by the code assessment team [2]. The RELAP-7 IV\&V activities, a major part of RELAP-7 assessment [3], should be in principle independent of the code development activities to ensure the quality of code [3]. Nonetheless, since the RELAP-7 features are still evolving, a certain level of communication between the code developers and code assessment team is inevitable, but must be done within the prescribed procedure. Furthermore, the RELAP-7 assessment plan and work scope should be set considering the RELAP-7 development status. Table 1 summarizes the work scope of RELAP-7 assessment corresponding to each stage of RELAP-7 development. The second column of Table 1, describing the RELAP-7 development status/plan, is given based on Ref. [1].

This document describes the continuing effort of RELAP-7 assessment plan and RELAP-7 IV\&V activities since FY-15. The specific contents include (i) RELAP-7 RTM update (section 3), (ii) a design of RELAP-7 RTM evaluation matrix and validation data gap identification (section 4), and (iii) RELAP-7 verification strategy and procedure (section 5). Also, a summary of previous RELAP-7 assessment activities are provided in section 2 to help readers understand the current work in a larger framework.

In the following subsections, we reiterate the work scope and objectives of RELAP-7 SVVP described in previous documents $[3,4]$ while incorporating the recent updates due to the RELAP-7 activities since 2016. This document is a "living" document because it will be updated as new or revised information is achieved through the future activities of RELAP-7 development and assessment. 
RELAP-7 Software Verification and Validation Plan: Requirements Traceability Matrix (RTM) Update and Code Verification Strategy

Table 1. RELAP-7 assessment work scope/plan according to the progress of RELAP-7 development

\begin{tabular}{|c|c|c|}
\hline & RELAP-7 development [1] & $\begin{array}{c}\text { RELAP-7 assessment } \\
\text { (including IV\& V activity) }\end{array}$ \\
\hline $\begin{array}{c}\text { Phase } 1 \\
\text { (Prototype code) }\end{array}$ & $\begin{array}{l}\text { - Develop a pilot code and demonstrate } \\
\text { the proof of concept } \\
\text { - Demonstrate the robustness of numerical } \\
\text { methods and physical models } \\
\text { - Numerical verification } \\
\text { - Validation with classical } \\
\text { phenomenological problems (e.g., water- } \\
\text { faucet, fill-drain, etc.) }\end{array}$ & $\begin{array}{l}\text { - Establish RTM } \\
\text { - Review on the availability and } \\
\text { accessibility of experimental data that can } \\
\text { be used for RELAP-7 code validation } \\
\text { - Validation data review }\end{array}$ \\
\hline $\begin{array}{c}\text { Phase } 2 \\
\text { (Demonstration code) }\end{array}$ & $\begin{array}{l}\text { - Implement real water/steam (IAPWS95 } \\
\text { package) and other material properties } \\
\text { - Implement/test major closure models } \\
\text { - Implement/test major components (e.g., } \\
\text { pipe, branch, valve, etc.) } \\
\text { - Some validation work with SET }\end{array}$ & $\begin{array}{l}\text { - Update RTM } \\
\text { - Validation data gap identification } \\
\text { - Establish verification coverage test suite } \\
\text { - Code verification for the basic } \\
\text { governing equations with available } \\
\text { options of boundary conditions, } \\
\text { stabilization schemes, and EOS, etc. } \\
\text { - Code verification for the major } \\
\text { components (e.g., pipe, branch, etc.). } \\
\text { - Simple V\&V work with FT and SET } \\
\text { problems listed in RELAP-7 RTM } \\
\text { - Documentation of (i) test results and (ii) } \\
\text { maturity level of independent V\&V }\end{array}$ \\
\hline $\begin{array}{c}\text { Phase } 3 \\
\text { (Production code) }\end{array}$ & $\begin{array}{l}\text { - Fully develop/test all the desired } \\
\text { features (e.g., input/output generation and } \\
\text { checking, error diagnostics) } \\
\text { - Implement/test all the closure } \\
\text { models/components/control systems } \\
\text { necessary for LWR simulation } \\
\text { - Full implementation of runtime } \\
\text { diagnostics } \\
\text { - Validate the code capabilities (e.g., } \\
\text { LOCA/reflood analyses) with SET/IET } \\
\text { - Define the code's applicability range } \\
\text { - Documentation } \\
\text { (e.g., theory manual, user' guide) }\end{array}$ & $\begin{array}{l}\text { - Validation work with a set of } \\
\text { constitutive models (e.g., wall/interfacial } \\
\text { momentum transfer, wall/interfacial } \\
\text { energy transfer, etc.) } \\
\text { - Validation work (CT and SET) with } \\
\text { PWR/BWR components (e.g., pressurizer, } \\
\text { centrifugal/jet pump, valve, U-tube steam } \\
\text { generator, steam separator/dryer, 1D } \\
\text { downcomer, etc.) } \\
\text { - Further validation work (SET) with } \\
\text { closure models such as CCFL, CHF, non- } \\
\text { condensable gas model and solute } \\
\text { transport model } \\
\text {------------------------------------------------ } \\
\text { - Full validation work with CT, SET, and } \\
\text { IET listed in RELAP-7 RTM } \\
\text { - Solution verification work for some } \\
\text { important safety analysis problems (e.g., } \\
\text { LOCA, reflood, SBO) } \\
\text { - Documentation of (i) test results and (ii) } \\
\text { maturity level of independent V\&V }\end{array}$ \\
\hline $\begin{array}{c}\text { Phase } 4 \\
\text { (Licensing code) }\end{array}$ & $\begin{array}{l}\text { - Transfer to end users of production code } \\
\text { - Incorporating proprietary models } \\
\text { - Extensive validation work } \\
\text { - Quality assurance process to obtain } \\
\text { approval from NRC }\end{array}$ & - \\
\hline
\end{tabular}

* Validation test type described in RELAP-7 Requirement Traceability Matrix (RTM):

FT: fundamental tests; CT: component tests; SET: separate effect tests; IET: integral effect tests 
RELAP-7 Software Verification and Validation Plan: Requirements Traceability Matrix (RTM) Update and Code Verification Strategy

\subsection{System Description}

The RELAP-7 (Reactor Excursion and Leak Analysis Program) code is a nuclear reactor system safety analysis code being developed at Idaho National Laboratory (INL). The code is based on the INL's modern scientific software development framework - MOOSE (Multi-Physics Object-Oriented Simulation Environment). The overall design goal of RELAP-7 is to take advantage of the previous thirty years of advancements in computer architecture, software design, numerical integration methods, and physical models. The end result will be a reactor systems analysis capability that retains and improves upon RELAP5's capability and extends the analysis capability for a variety of reactor system simulation scenarios.

\subsection{Plan Objectives}

The objective of this plan is to document the verification and validation activities for the software development process for RELAP-7. Additional information provided in this plan includes the Requirement Traceability Matrix which is the set of General Requirements, Specific Requirements and Code V\&V Requirements.

For the INL, Software Quality Assurance (SQA) requirements are contract driven and interpreted from DOE Order 414.1D, "Quality Assurance”, 10 CFR 830 "Nuclear Safety Management”, Subpart A, "Quality Assurance Requirements", and ASME NQA-1-2008 with the NQA-1a-2009 addenda, "Quality Assurance Requirements for Nuclear Facility Applications." The INL internal document, PDD-13610 (Revision 13, 4/1/2015), "Software Quality Assurance Program" describes the SQA Program at the INL:

- PDD-13610 describes the Software Quality Assurance Program, which INL applies, to confirm that software used at INL is consistent with applicable requirements and is directed towards preventing software errors from occurring. The SQA Program includes a systematic set of standards, conventions, and methodologies implementing a standardized approach to the life cycle for all software at INL.

Per PDD-13610, INL SQA Program applies to all organizations, facilities, programs, projects, and subcontractors. The extent to which the program establishes required SQA activities is determined by the risk or quality level associated with failure of the software to meet established requirements. This graded approach consists of activities and sub-activities that can be implemented at varying levels of rigor based upon the potential impact on safety and the type of software. The more critical the software, the more formal and detailed the SQA activities must be performed and documented. Implementation of the SQA Program focuses on a life cycle management approach for Information Technology (IT) assets. This approach is described in LWP-13620, "Managing Information Technology Assets." The INL technology developed and/or used within RISMC pathway (e.g., RELAP-7) also follows the LWP-13620.

PDD-13610 defines "Software" as Computer programs and associated documentation and data pertaining to the operation of a computer system and includes application software and support software [ASME NQA-1-2008 with the NQA-1a-2009 addenda edited]. Other softwares are defined as:

- Application software - A type of software designed to help users perform particular tasks or handle particular types of problems, as distinct from software tools (e.g., compilers) and system software (see def.) that controls the computer itself. Examples include timesheet, payroll, Electronic Document Management System (EDMS), Microsoft Excel spreadsheets, computer models, or process control applications. [ISO/IEC/IEEE Std. 24765-2010 edited] 
RELAP-7 Software Verification and Validation Plan: Requirements Traceability Matrix (RTM) Update and Code Verification Strategy

- Support Software - Software that includes software tools (e.g., compilers) and system software. [ASME NQA-1-2008 with the NQA-1a-2009 addenda]

Note that within the INL SQA process, software that does not fall within the scope of the SQA Program includes any software covered by a contractual agreement, such as Work for Others, which includes references or requires a specific documented SQA process.

Applicable documents that apply to RELAP-7 development include:

- Software Quality Assurance Plan for RELAP-7, PLN-4212, 5/31/2012.

- Software Configuration Management Plant for the RELAP-7 Project, PLN-4214, 6/28/2012.

- Software Verification and Validation Plan for RELAP-7, PLN-4215, 6/28/2012.

- $\quad$ RELAP-7 Development Plan, INL/MIS-13-28183, 1/2013.

It is the responsibility of the Software Owner to make the determination as to whether a particular software can be classified as "Safety Software." Safety Software includes the following type of softwares:

- Safety System Software. Software for a nuclear facility that performs a safety function as part of a structure, system, or component and is cited in either (a) a DOE approved documented safety analysis or (b) an approved hazard analysis per DOE P 450.4, "Safety Management System Policy", dated 10-15-96, (or latest version) and 48 CFR 970-5223.1.

- Safety Analysis and Design Software. Software that is used to classify, design, or analyze nuclear facilities. This software is not part of a structure, system, or component (SSC) but helps to ensure that the proper accident or hazards analysis of nuclear facilities or an SSC that performs a safety function.

- Safety Management and Administrative Controls Software. Software that performs a hazard control function in support of nuclear facility or radiological safety management programs or technical safety requirements or other software that performs a control function necessary to provide adequate protection from nuclear facility or radiological hazards. This software supports eliminating, limiting or mitigating nuclear hazards to worker, the public, or the environment as addressed in 10 CFR Parts 830 and 835, the DEAR Integrated Safety Management System clause, and 48 CFR 970-5223.1. [DOE O 414.1D]

For all software that falls within the scope of the SQA Program, a quality level must be assigned by a qualified Quality Level Analyst with review and concurrence by a Quality Level Reviewer (i.e., a second Quality Level Analyst) per LWP-13014 (4/25/2013), "Determining Quality Levels." The Quality Level Analyst should then communicate to the Software Owner the determined quality level.

There is no consistent definition for the term Quality Level (QL). QLs only serve as a designator to identify the unmitigated risk or potential consequence level associated with the failure of an item or activity and to facilitate communication for a common understanding of the rigor to be applied through the appropriate implementation procedures:

Quality Level 1 High unmitigated risk or high potential consequence level of failure

Quality Level 2 Medium unmitigated risk or medium potential consequence level of failure 
RELAP-7 Software Verification and Validation Plan: Requirements Traceability Matrix (RTM) Update and Code Verification Strategy

Quality Level 3 Low unmitigated risk

Quality Level 4 No risk item or service

The risk analysis used to designate QLs must be performed by personnel designated, trained, and qualified as QL Analysts. This initial training and every 3-year requalification of QL Analysts, also established by this procedure, is necessary to implement the graded approach effectively.

All documentation that furnishes evidence of the software quality is considered a QA record and should be handled as a quality record according to the organization, program, or project's "Records Management" as required by LWP-1202. QA records generated during the software development life cycle could include project plans, requirement specifications, configuration management plans, software quality assurance plans, security plans, and verification and validation documentation (e.g., test plans, test cases, and design review documents). Per LWP-1202, "Records Management," the INL Records Schedule Matrix, and associated record types list(s) provide current information on the retention, quality assurance, and/or destruction moratorium requirements for these records. Contact a Records Coordinator for assistance if needed.

It is the responsibility of the contractor to ensure that these quality criteria are adequately addressed throughout the course of the research that is performed.

\subsubsection{Software Quality Assurance}

Software assurance is the planned and systematic set of activities that ensures that software processes and products conform to requirements, standards, and procedures. These processes are followed in order to enhance the robustness of the development process. Having formal documented development procedures and requirements helps to streamline the development cycle and focus on customer-driven needs.

In an attempt to improve the quality of the RELAP-7 tool set, effort has been made to establish criteria to which the development and control processes adhere. The recording of coding standards and the creation of the Requirements Traceability Matrix (RTM) will be added to improve code use and to establish traceability.

The roles and responsibilities of each team member are described below:

- Project Manager - Executes, maintains, and updates this plan. Monitors SV\&V activities for the RELAP-7 Project. Coordinates formal user acceptance testing, when required. Performs as an alternate for technical team members.

- Software Developer - Performs design reviews, test case identification, design, construction, and functional unit testing during software development; reports anomalies and deviations to the Project Manager.

- Quality Assurance - Supports SV\&V activities including RELAP-7 reviews. Is independent of the development and testing work 
RELAP-7 Software Verification and Validation Plan: Requirements Traceability Matrix (RTM) Update and Code Verification Strategy

\subsection{Supporting Activities}

\subsubsection{Development of MOOSE Application}

RELAP-7 is a MOOSE (Multiphysics Object-Oriented Simulation Environment) based application which uses open source software packages, such as PETSC (a nonlinear solver developed at Argonne National Laboratory) and LibMesh (a Finite Element Analysis package developed at University of Texas). MOOSE provides numerical integration methods and mesh management for parallel computation. Therefore RELAP-7 code developers only need to focus upon the physics and user interface capability. By using the MOOSE development environment, RELAP-7 code is developed by following the same modern software design paradigms used for other MOOSE development efforts.

There are currently over 20 different MOOSE based applications ranging from 3-D transient neutron transport, detailed 3-D transient fuel performance analysis, to long-term material aging. Multiphysics and multiple dimensional analyses capabilities, such as radiation transport, can be obtained by coupling RELAP-7 and other MOOSE-based applications through MOOSE. This allows restricting the focus of RELAP-7 to systems analysis-type simulations.

The RISMC Toolkit is being built using the INL's MOOSE framework. MOOSE has been designed to solve multi-physics systems that involve multiple physical models or multiple simultaneous physical phenomena. Inside MOOSE, the Jacobian-Free Newton Krylov (JFNK) method is implemented as a parallel nonlinear solver that naturally supports effective coupling between physics equation systems (or Kernels). This capability allows for a tightly-coupled set of tools that work together, as shown in Figure 1.



Figure 1. MOOSE-based applications 
RELAP-7 Software Verification and Validation Plan: Requirements Traceability Matrix (RTM) Update and Code Verification Strategy

\subsubsection{Technology Transfer}

Development of RELAP-7 is to support US nuclear power industry and technical stewardship is envisaged. To realize this long-term vision, several items are considered.

The RELAP-7 quality assurance (QA) process includes the specific activities of verification, validation, assessment, and related documentation to facilitate reviews of these activities. To support these QA activities, a various results from facility operation, integral effects test, separate effect tests, and fundamental tests including experiments on individual components have been collected. The INL has started the QA process by implementing modern software management processes (including the use of tools such as source code version control) as a part of the RELAP-7 development, conducting NQA-1 audits, and creating a software verification and validation plan (SVVP).

The type of software license for RELAP-7 is still to be determined. RELAP-7 is subject to U.S. Export Control laws, including a complete embargo against any person from a T5 country (currently: Cuba, Iran, North Korea, Syria and Sudan). The software license for the supporting MOOSE framework is the open source license "Lesser GNU Public License (LGPL) version 2.1."

\subsection{RELAP-7 Features}

In general RELAP-7 provides computational simulation of thermal-hydraulic behavior in a nuclear power plant and its components. Representative thermal hydraulic models are used to depict the major physical components and describe major physical processes. RELAP-7 has five main types of components/capabilities:

- Three-dimensional (3D) analysis coupled with other physics applications

- Two dimensional (2D)

- One-dimensional (1D) components (e.g., pipe)

- Zero-dimensional (0D) components for setting boundary conditions for the 1D components (e.g., Pressure boundary condition of pump)

- OD components for connecting 1D components

RELAP-7 could be coupled to 3D core modeling MOOSE-based codes to enable detailed resolution.

The RELAP-7 code development started in 2012 based upon development input from the Electric Power Research Institute. During the first year of the code development, the software framework was created to establish the basic reactor system simulation capability with a number of components developed for single-phase thermal fluid flow. Later, two-phase flow modeling capability was implemented in the RELAP-7 code. These early capabilities have been demonstrated via application to a boiling water reactor simulation with representative components under extended Station Black Out (SBO) transient conditions.

The RELAP-7 $\alpha-0.1$ was released in May 2012, and followed by $\alpha-0.2$ versions in August 2013 and $\alpha-0.6$ versions in September 2014. Since 2015, the code developers are using GitLab project which is the web base open community for code developers. The GitLab will automatically provide code version number when the code has been updated. 

Verification Strategy

The RELAP-7 application is the next generation nuclear reactor system safety analysis code. The code is based upon the MOOSE (Multi-Physics Object-Oriented Simulation Environment). The goal of RELAP-7 development is to leverage of advancements in software design, numerical integration methods, and physical models.

The Homogeneous Equilibrium two-phase flow Model (HEM) has been archived. 
RELAP-7 Software Verification and Validation Plan: Requirements Traceability Matrix (RTM) Update and Code Verification Strategy

Table 2. Component-related attributes for the RELAP-7 (as of 2017)

\begin{tabular}{|c|c|c|c|c|c|c|}
\hline \multirow[b]{2}{*}{ RELAP-7 Component } & \multicolumn{3}{|c|}{ Dimensionality } & \multicolumn{2}{|c|}{ Hydrodynamic Model } & \multirow{2}{*}{$\begin{array}{l}\text { 3D Linkage } \\
\text { Application }\end{array}$} \\
\hline & OD & 1D & $2 \mathrm{D}$ & Single Phase & $\begin{array}{c}\text { Two Phase } \\
\text { 7-Eq. }\end{array}$ & \\
\hline Inlet & $\square$ & $\mathrm{n} / \mathrm{a}$ & $\mathrm{n} / \mathrm{a}$ & - & - & $\mathrm{n} / \mathrm{a}$ \\
\hline Outlet & घ & $\mathrm{n} / \mathrm{a}$ & $\mathrm{n} / \mathrm{a}$ & - & - & $\mathrm{n} / \mathrm{a}$ \\
\hline SolidWall & - & $\mathrm{n} / \mathrm{a}$ & $\mathrm{n} / \mathrm{a}$ & - & - & $\mathrm{n} / \mathrm{a}$ \\
\hline Pipe & $\mathrm{n} / \mathrm{a}$ & - & $\mathrm{n} / \mathrm{a}$ & - & - & BISON \\
\hline PipeWithHeatStructure & $\mathrm{n} / \mathrm{a}$ & घ & घ & - & घ & $\mathrm{n} / \mathrm{a}$ \\
\hline HeatStructure & $\mathrm{n} / \mathrm{a}$ & $\mathrm{n} / \mathrm{a}$ & - & $\mathrm{n} / \mathrm{a}$ & $\mathrm{n} / \mathrm{a}$ & $\mathrm{n} / \mathrm{a}$ \\
\hline HeatGeneration & $\mathrm{n} / \mathrm{a}$ & $\mathrm{n} / \mathrm{a}$ & - & $\mathrm{n} / \mathrm{a}$ & $\mathrm{n} / \mathrm{a}$ & $\mathrm{n} / \mathrm{a}$ \\
\hline CoreChannel & $\mathrm{n} / \mathrm{a}$ & - & - & - & - & $\mathrm{n} / \mathrm{a}$ \\
\hline VolumeBranch & - & $\mathrm{n} / \mathrm{a}$ & $\mathrm{n} / \mathrm{a}$ & - & $\square$ & $\mathrm{n} / \mathrm{a}$ \\
\hline Branch & - & $\mathrm{n} / \mathrm{a}$ & $\mathrm{n} / \mathrm{a}$ & - & $\square$ & $\mathrm{n} / \mathrm{a}$ \\
\hline Valve & $\square$ & $\mathrm{n} / \mathrm{a}$ & $\mathrm{n} / \mathrm{a}$ & - & $\square$ & $\mathrm{n} / \mathrm{a}$ \\
\hline CompressibleValve & - & $\mathrm{n} / \mathrm{a}$ & $\mathrm{n} / \mathrm{a}$ & - & $\square$ & $\mathrm{n} / \mathrm{a}$ \\
\hline CompressibleBranch & $\Delta$ & $\mathrm{n} / \mathrm{a}$ & $\mathrm{n} / \mathrm{a}$ & $\Delta$ & $\square$ & $\mathrm{n} / \mathrm{a}$ \\
\hline CheckValve & - & $\mathrm{n} / \mathrm{a}$ & $\mathrm{n} / \mathrm{a}$ & - & $\square$ & $\mathrm{n} / \mathrm{a}$ \\
\hline IdealPump & $\square$ & $\mathrm{n} / \mathrm{a}$ & $\mathrm{n} / \mathrm{a}$ & - & $\mathrm{n} / \mathrm{a}$ & $\mathrm{n} / \mathrm{a}$ \\
\hline Pump & $\square$ & $\mathrm{n} / \mathrm{a}$ & $\mathrm{n} / \mathrm{a}$ & - & $\square$ & $\mathrm{n} / \mathrm{a}$ \\
\hline PointKinetics & - & $\mathrm{n} / \mathrm{a}$ & $\mathrm{n} / \mathrm{a}$ & $\mathrm{n} / \mathrm{a}$ & $\mathrm{n} / \mathrm{a}$ & $\mathrm{n} / \mathrm{a}$ \\
\hline SeparatorDryer & - & $\mathrm{n} / \mathrm{a}$ & $\mathrm{n} / \mathrm{a}$ & $\mathrm{n} / \mathrm{a}$ & $\square$ & $\mathrm{n} / \mathrm{a}$ \\
\hline Downcomer & - & $\mathrm{n} / \mathrm{a}$ & $\square$ & $\mathrm{n} / \mathrm{a}$ & $\square$ & $\mathrm{n} / \mathrm{a}$ \\
\hline WetWell & - & $\square$ & $\mathrm{n} / \mathrm{a}$ & - & $\square$ & $\mathrm{n} / \mathrm{a}$ \\
\hline PrescribedReactorPower & - & $\mathrm{n} / \mathrm{a}$ & $\mathrm{n} / \mathrm{a}$ & $\mathrm{n} / \mathrm{a}$ & $\mathrm{n} / \mathrm{a}$ & $\mathrm{n} / \mathrm{a}$ \\
\hline Turbine & $\square$ & $\mathrm{n} / \mathrm{a}$ & $\mathrm{n} / \mathrm{a}$ & - & $\square$ & $\mathrm{n} / \mathrm{a}$ \\
\hline Pressurizer & $\Delta$ & $\square$ & $\mathrm{n} / \mathrm{a}$ & $\mathrm{n} / \mathrm{a}$ & $\square$ & $\mathrm{n} / \mathrm{a}$ \\
\hline Accumulator & $\Delta$ & $\square$ & $\mathrm{n} / \mathrm{a}$ & $\mathrm{n} / \mathrm{a}$ & $\square$ & $\mathrm{n} / \mathrm{a}$ \\
\hline Steam Generator & $\mathrm{n} / \mathrm{a}$ & $\square$ & $\mathrm{n} / \mathrm{a}$ & $\mathrm{n} / \mathrm{a}$ & $\square$ & $\mathrm{n} / \mathrm{a}$ \\
\hline Jet Pump & $\mathrm{n} / \mathrm{a}$ & $\square$ & $\mathrm{n} / \mathrm{a}$ & $\mathrm{n} / \mathrm{a}$ & $\square$ & $\mathrm{n} / \mathrm{a}$ \\
\hline
\end{tabular}

* a: Available, $\Delta$ : Under review (developed, but not merged yet), $\square:$ Planned, n/a: Not applicable 
RELAP-7 Software Verification and Validation Plan: Requirements Traceability Matrix (RTM) Update and Code Verification Strategy

In summary the RELAP-7 design is based upon:

- Modern Software Design:

- Object-oriented $\mathrm{C}++$ construction provided by the MOOSE framework

- Designed to significantly reduce the expense and time of RELAP-7 development

- Designed to be easily extended and maintain

- Meets NQA-1 requirements

- Advanced Numerical Integration Methods:

○ Multi-scale time integration, PCICE (operator split), JFNK (implicit nonlinear

Newton method), and a point implicit method (long duration transients)

- New pipe network algorithm based upon Mortar FEM (Lagrange multipliers)

- Ability to couple to multi-dimensional reactor simulators

- State-of-the-Art Physical Models:

- All-speed, all-fluid (vapor-liquid, gas, liquid metal) flow

○ Well-posed 7-equation two-phase flow model

- New reactor heat transfer model based upon fuels performance

Table 2 summarizes the development status of major components for RELAP-7 (as of 2017).

\subsubsection{Software Framework}

The RELAP-7 (Reactor Excursion and Leak Analysis Program) code is based on INL developed framework software MOOSE (Multi-Physics Object Oriented Simulation Environment) which may model fully coupled nonlinear partial differential equations. The Graphical User Interface (GUI) of RELAP-7 can be provided by other MOOSE based softwares.

\subsubsection{Governing Theory}

Fundamentally, the RELAP-7 code is designed to simulate all-speed and all-fluid for both single and two-phase flow. However, current status RELAP-7 development focuses on simulation of the light water reactors (LWR), thus, two-phase flow model is described here.

The main governing theories of RELAP-7 are: 7-equation two-phase flow; reactor core heat transfer; and reactor kinetics models.

The 7-equation two-phase flow model consists of mass, momentum and energy (or pressure) equation for both liquid and vapor phases and a topological equation which explains the state of the twophase mixture. This model may solve compressible fluid at all-speed multiphase flow which allows analyzing various transient phenomena and accident scenarios in LWR. In the RELAP-7, the 7-equation model is implemented in the MOOSE finite element framework.

Both convective and conduction heat transfer is simulated for fuel, fluid, and structures. The reactor core heat source is modeled by point kinetic method considering hydraulic reactivity feedback. The three-dimensional reactor kinetics may simulate through coupling with RattleSNake which is a reactor kinetics code with both diffusion and transport capabilities based on MOOSE framework. 


\subsubsection{Computational Approach}

The RELAP-7 uses MOOSE-based applications with a multitude of mathematical and numerical libraries: LibMesh for the second-order accurate spatial discretization by employing linear basis, onedimensional finite elements; Message Passing Interface (MPI) for distributed parallel processing; Intel Threading Building Blocks (Intel TBB) for parallel C++ programs to take full advantage of multi-core architecture found in most large-scale machines; and PETSc, Trilinos and Hypre for the mathematical libraries and nonlinear solver capabilities for Jacobian-Free Newton Krylov (JFNK).

To cover various time scale range of reactor transient and accident scenarios, the RELAP-7 pursues three-level time integration approaches: Pressure-Corrected Implicit Continuous-fluid Eulerian (PCICE) computational fluid dynamics (CFD) scheme for highly compressible and/or contain significant energy deposition, chemical reactions, or phase change problems; JFNK method for multi-physics problems during the transients; Point Implicit time Integration method for long duration and slow transient scenarios. 


\section{RELAP-7 INDEPENDANT VERIFICATION AND VALIDATION PLAN}

The work described in this document, such as RELAP-7 RTM update (section 3), RTM evaluation matrix (section 4), and code verification plan/strategy (section 5) is based on the framework that has been established since 2015. This section summarizes the previous activity of RELAP-7 IV\&V to help readers to understand the present work in the context of such a big frame.

\subsection{RELAP-7 Code Assessment Plan and RTM Establishment [3]}

The RELAP-7 code assessment strategy was established and efforts were made to identify the RELAP-7 test requirements. Then, the code assessment plan was proposed in the form of Requirement Traceability Matrix (RTM), the activity of which was first started in 2015 [4]. The RELAP-7 RTMs have been created by assembling all the necessary information, i.e., RELAP-7 test requirements, into the condensed form of matrices. Consequently, this allows us to effectively trace the progress of code development as well as the code V\&V (or assessment). As of 2017, the RELAP-7 RTM consists of three elements, (i) general RTM, (ii) specific RTM, and (iii) code $V \& V R T M$, as shown in Figure 2. The general $R T M$ involves a set of general requirements in order for RELAP-7 to play a role as a next-generation nuclear system analysis code; the specific RTM contains a set of technical aspects of requirements. In particular, rhea requirements related to the legacy issues of existing nuclear system codes are included in this specific RTM; the code $V \& V R T M$ provides a detailed list of $\mathrm{V} \& \mathrm{~V}$ test problems for RELAP-7. 
RELAP-7 Software Verification and Validation Plan: Requirements Traceability Matrix (RTM) Update and Code Verification Strategy

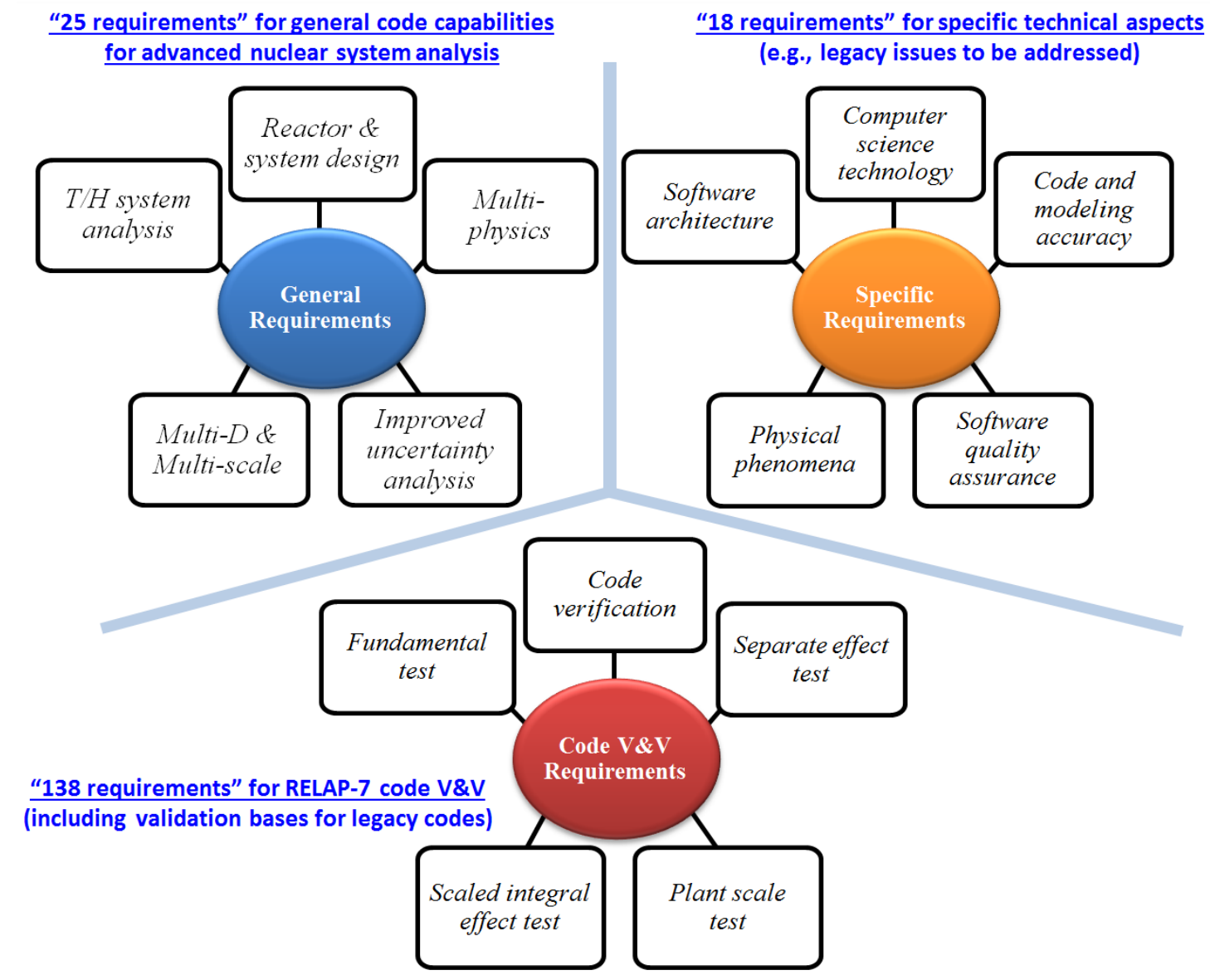

Figure 2. Characterization of requirements for RELAP-7 RTM (as of 2017)

\subsection{Code Verification and Validation Activity [2]}

Among the list of $\mathrm{V} \& \mathrm{~V}$ test problems in RELAP-7 code $V \& V R T M$, five test problems were selected and used to assess the RELAP-7 simulation capability (as of 2016). The three tests were performed for code verification while the other two tests were performed for code validation. The two verification tests were conducted at hydrostatic condition that did not account for gravity. The test results verified that the hydrostatic equilibrium was well maintained during the simulation. However, the vapor velocity was observed to fluctuate significantly by introducing a gravity term. The other verification test was to investigate the advection of void fraction through a horizontal channel, which is schematically illustrated in Figure 3 (top side). The RELAP-7 simulation result shown in Figure 3 (bottom side) indicates that the profile of initially-given void fraction is deformed significantly due to the numerical errors such as numerical dissipation and dispersion. In particular, it was found that the code often failed when the void fraction values became negative during the simulation as a result of the numerical dispersion. Also, one of the validation tests with 'water-faucet test problem' revealed that mixted boundary condition needs to be better addressed in RELAP-7. The other validation test was performed with 'phase-separation test problem' as shown in Figure 4. This test problem assumed that the vertical pipe was initially filled with the two-phase mixture of uniform void fraction (see the top of Figure 4). Then, the two different phases, i.e., liquid and vapor, were expected to be separated over time due to the effect of gravity. The RELAP-7 simulation results for this test were largely reasonable as shown on the 
RELAP-7 Software Verification and Validation Plan: Requirements Traceability Matrix (RTM) Update and Code Verification Strategy

bottom of Figure 4, but it was concluded that more attention still needs be paid to the fluctuating behavior of void fraction observed during the simulation.

The above V\&V tests were good confidence-building excercises for RELAP-7, but at the same time several issues were found while running the code as noted above. As a result, we reached a conclusion that more strict code verification work is required. This motivated the establishment of RELAP-7 code verification plan and strategy detailed in section 5.

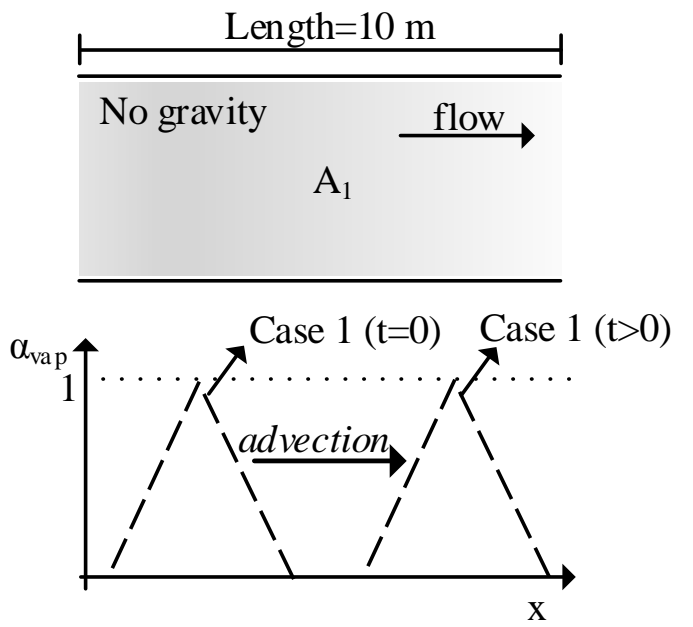

$$
\begin{aligned}
& \text { [Initial Condition] } \\
& \mathrm{u}_{\mathrm{liq}}=\mathrm{u}_{\mathrm{vap}}=0.1[\mathrm{~m} / \mathrm{s}], \mathrm{p}_{\mathrm{liq}}=\mathrm{p}_{\mathrm{vap}}=1 \mathrm{e} 5[\mathrm{pa}] \\
& \alpha_{\mathrm{vap}}=\text { spatially varying }(\text { Case } 1-\text { Case } 3) \\
& \mathrm{A}_{1}=1.9 \mathrm{e}-4\left[\mathrm{~m}^{2}\right], \mathrm{L}=10[\mathrm{~m}]
\end{aligned}
$$

\section{[Boundary Condition]}

inlet: Inlet $\left(\mathrm{u}_{\mathrm{liq}}=\mathrm{u}_{\mathrm{vap}}=0.1[\mathrm{~m} / \mathrm{s}], \mathrm{p}_{\mathrm{liq}}=\mathrm{p}_{\mathrm{vap}}=1 \mathrm{e} 5[\mathrm{pa}]\right)$

outlet: Outlet $\left(\mathrm{p}_{\mathrm{liq}}=\mathrm{p}_{\mathrm{vap}}=1 \mathrm{e} 5[\mathrm{pa}]\right)$

\section{[Stabilizations] \\ EntropyViscosity}

[Theoretically anticipated advection of void fraction profile]
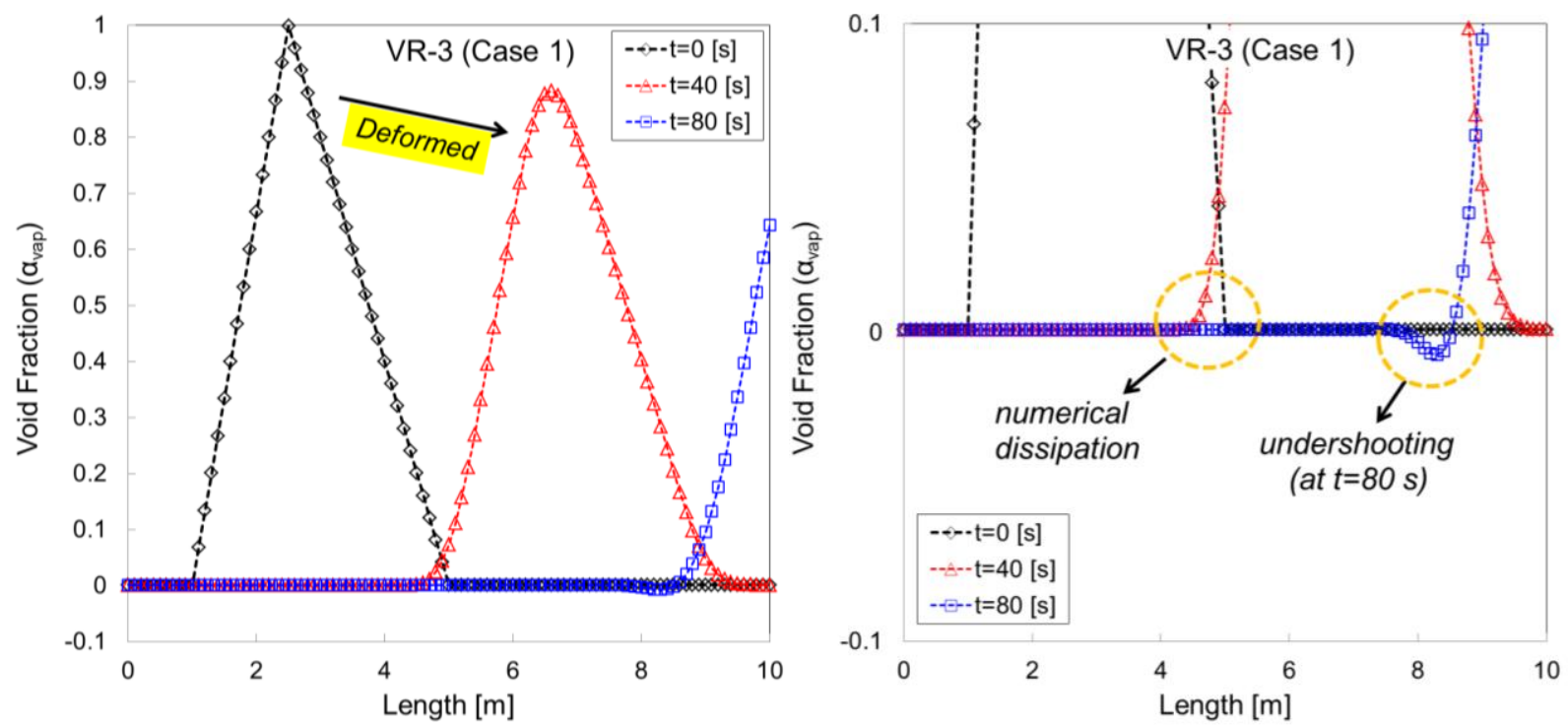

Figure 3. RELAP-7 test setup for void fraction advection problem (top) and test result (bottom) [2] 
RELAP-7 Software Verification and Validation Plan: Requirements Traceability Matrix (RTM) Update and Code Verification Strategy

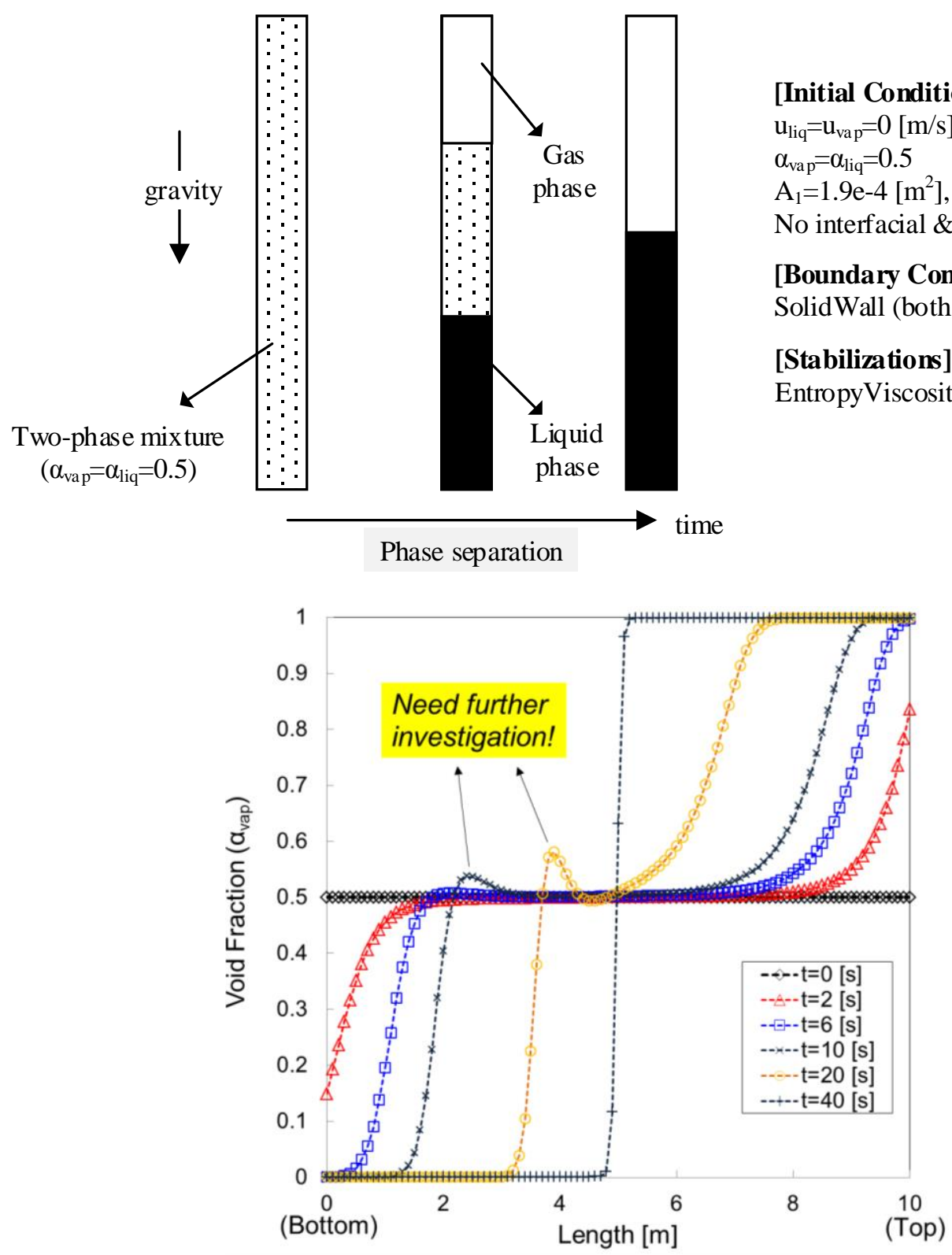

Figure 4. RELAP-7 test setup for phase-separation problem (top) and test result (bottom) [2] 
RELAP-7 Software Verification and Validation Plan: Requirements Traceability Matrix (RTM) Update and Code Verification Strategy

\section{RELAP-7 RTM UPDATE}

As noted in section 2, the current RELAP-7 RTM consists of three elements (i) general RTM, (ii) specific RTM, and (iii) code $V \& V R T M$, the framework of which has been constructed and modified since $2015[3,4]$. In this fiscal year, three major updates have been made while maintaining this framework:

First, a set of V\&V test problems used for SPACE code validation [5] were reviewed and some of the test items were added to the RELAP-7 code $V \& V R T M$. According to No et al. (2012) [5], the SPACE code V\&V has been performed in two separate stages, Phase I (model verification test, integration test, and conceptual problem test) and Phase II (integral effect test). Some of the validation test items have been found to be useful for reducing the validation data gap identified during the establishment of RELAP-7 RTM evaluation matrix (see section 4 for details). For example, as of 2017, the RELAP-7 code $V \& V R T M$ needs more validation data for "flow split" phenomenon (see section 4 for details), while the related validation tests were already done for the SPACE code, i.e., "branch reentrant tee/cross-flow tee/cross tank problems." (see TABLE II in No et al. (2012)). This information seems to be very useful and would be great if it could be included into the RELAP-7 validation plan. The detailed information on the validation tests, however, will become available after the SPACE code manual is released.

Second, several requirement items in the RELAP-7 RTM were rearranged so that they fall into the proper categories. Two items in the previous code $V \& V R T M$ have been moved to the sub-category of software quality assurance in the specific RTM (see Figure 2). Also, two test items were newly added to the sub-category of fundamental test in the code $V \& V R T M$; one is for the entrainment/de-entrainment in horizontal flow and the other is for offtake test. Some requirement descriptions and references in the code $V \& V R T M$ have also been improved to clarify the test objective.

Third, the 'RELAP-7 Test Status' in the code V\&V RTM has been updated. Specifically, new classifiers of six level (i.e., tested, partly tested, testable, in progress, not ready, need to check) have been introduced. These classifiers were applied by considering the development and IV\&V status of RELAP-7 as of 2017. Consequently, this will continue to be updated as the RELAP-7 development and IV\&V work progresses. For the future IV\&V activity of RELAP-7, a priority will be given to the tasks that have been classified as "testable", "in progress" and "partly tested" in this updated code V\&V RTM.

The detailed updates for RELAP-7 RTM are summarized in Table 3. The full version of RELAP-7 RTM reflecting these updates are given in Appendix. 
RELAP-7 Software Verification and Validation Plan: Requirements Traceability Matrix (RTM) Update and Code Verification Strategy

Table 3. Details of the RELAP-7 RTM update

\begin{tabular}{|c|c|c|c|}
\hline & Existing ID & Updated ID & Requirement specification (updated) \\
\hline General RTM & GR-6 & Deleted & \\
\hline \multirow[t]{2}{*}{ Specific RTM } & - & SR-17 & $\begin{array}{l}\text { Check consistency of code results depending } \\
\text { on computer hardware and software } \\
\text { environment (e.g., compiler, libraries, etc.) }\end{array}$ \\
\hline & - & SR-18 & $\begin{array}{l}\text { Regression test and code coverage test after } \\
\text { any updates in the source code }\end{array}$ \\
\hline \multirow{15}{*}{ Code V\&V RTM } & VR-8 & Deleted & $\begin{array}{l}\text { Iterative scheme convergence tests (e.g., } \\
\text { JFNK) }\end{array}$ \\
\hline & VR-11 & VR-10 & $\begin{array}{l}\text { Conservation tests in 0-D \& 1-D components } \\
\text { (e.g., Branches/Junctions, LWR components } \\
\text { like steam generator or pressurizer, pipe) }\end{array}$ \\
\hline & VR-13 & Deleted & - \\
\hline & VR-15 & Deleted & - \\
\hline & VR-18 & Deleted & - \\
\hline & VR-33 & VR-29 & Convective heat transfer (single-phase) \\
\hline & VR-19 & VR-13 & $\begin{array}{l}\text { Gravitational head effect \& Countercurrent } \\
\text { flow development }\end{array}$ \\
\hline & VR-20 & VR-14 & Heat conduction (1D/Multi-D) \\
\hline & VR-21 & VR-15 & $\begin{array}{l}\text { Decay heat model test with various decay } \\
\text { options }\end{array}$ \\
\hline & VR-22 & VR-16 & Reactor kinetics model \\
\hline & VR-23 & VR-17 & $\begin{array}{l}\text { Metal-water reaction model } \\
\text { (e.g., Zr-cladding oxidation) }\end{array}$ \\
\hline & VR-24 & VR-18 & Wall-to-fluid friction (single phase) \\
\hline & VR-25 & VR-19 & Single-phase shock problem \\
\hline & - & VR-37 & $\begin{array}{l}\text { Entrainment/de-entrainment in horizontal } \\
\text { flow }\end{array}$ \\
\hline & - & VR-54 & Offtake test \\
\hline
\end{tabular}




\section{EVALUATION MATRIX FOR RELAP-7 RTM AND VALIDATION DATA GAP}

This section describes the evaluation matrices for the RELAP-7 code $V \& V R T M$. The purpose of creating the evaluation matrix is to check the overall suitability of the test requirements included in the RELAP-7 code $V \& V R T M$. The examples are shown in Tables 4 and 5, which are the evaluation matrices for the fundamental tests (FT) and the separate effect tests (SET) included in the RELAP-7 code V\&V $R T M$, respectively. These matrices provide an efficient way to check how well the test problems (or test requirements) in the code $V \& V R T M$ are organized to demonstrate the RELAP-7 simulation capability. The RELAP-7, as an advanced nuclear system safety analysis code, must be proven to have the simulation capability on the phenomena considered important for the LWR safety. The left column of Tables 4 and 5 lists the generic single-phase and two-phase phenomena considered important in the safety analysis of LWR system. The list of these phenomena has been created based on the collaborative effort with EPRI [6], reviewing the OECD/NEA report [7], and considering the demand for the future nuclear system analysis codes as described in Ref. [8,9] and in our previous report [3].

The first row of Tables 4 and 5 lists the requirement ID (e.g., VR-xx) used in the RELAP-7 code $V \& V R T M$. The check mark $(\mathrm{V})$ in the matrices indicates that the phenomena listed in the left column can be addressed by the validation test problems provided in the code $V \& V R T M$. Note that this check mark is used only when we have the specific data to compare with the simulation results. If there is no validation data available for a given task (or phenomenon), despite mentioning the need in the RELAP-7 code $V \& V$ $R T M$, the entire row is shaded in red and an asterisk (*) is added to the place of corresponding requirement ID as shown in Tables 4 and 5.

The RELAP-7 RTM evaluation matrix provides several benefits. First, the matrices effectively present how well the RELAP-7 V\&V plan has been designed in view of addressing the wide range of safely phenomena relevant for the analysis of LWR system. Second, the validation data gap can be clarified at a glance, allowing us to focus on the areas where further research (e.g., experiment) is needed. Lastly, the V\&V status of RELAP-7 at a specific point in time can be easily checked at the management level with these tables. To do this, the identifiers should be improved to better specify the code V\&V status (e.g., O: completed, $\Delta$ : in progress, $\times$ : not started).

Given the present RELAP-7 RTM evaluation matrices (Tables 4 and 5), the validation data gaps are identified as follows:

\section{- Flow split (single-phase)}

- Single-phase convective heat transfer (especially, forced laminar and natural convective heat transfer for vertical bundles)

- Boiling heat transfer under forced or free convection within geometries other than tube (e.g., vertical bundle, annulus)

- Condensation heat transfer

\section{- Phase separation at branches}

\section{- Boron mixing and transport}

In particular, the validation data are found to be significantly lacking for the three test items marked in bold in the six items above, i.e., 'Flow split', 'Phase separation at branches', and 'Boron mixing and transport'. No validation data for these test problems exist in the current code $V \& V R T M$. As for the 
RELAP-7 Software Verification and Validation Plan: Requirements Traceability Matrix (RTM) Update and Code Verification Strategy

single-phase convective heat transfer, there is no correlation for the forced laminar and natural convective heat transfer for vertical bundles and hence further research is required [10]. More validation data for 'Boiling heat transfer' are also required in view of the fact that the validation data in the current RELAP-7 code $V \& V R T M$ are available only for the tube geometry. Lastly, although there are some validation data for 'Condensation heat transfer', it is still judged to be insufficient.

In the context of RELAP-7 IV\&V plan and validation data gap described above, INL is collaborating with the University partner, University of Illinois at Urbana-Champaign (UIUC), under Nuclear Energy University Program (NEUP Project 16-10630). It is noted that the experimental effort made by UIUC is in line with the effort for reducing the validation data gap especially for the items 'Single-phase convective heat transfer' and 'Boiling heat transfer'. The general description on the experiment is given as follows:

Natural circulation experiments are to be performed at University of Illinois at Urbana-Champaign in the Multiphase Thermo-fluid Dynamics Laboratory. The closed loop facility fitted with a condenser, 18 $\mathrm{kW}$ preheater, high-temperature pump, test section with $54 \mathrm{~kW}$ custom immersion heater, and pressurizing tank can acquire detailed measurements in single-phase and two-phase natural and forced convection flows. The 5 meter test section geometry is an annulus with 3 meters of vertical heated length, followed by 2 meters of unheated length. Five measurement ports along the test section measure pressure, liquid temperature, and two-phase properties such as void fraction, gas velocity, and interfacial area concentration. Pressure and temperature is measured at many location around the facility, flow rate is measured upstream of the test section using a magnetic flowmeter, and the custom heater has five imbedded thermocouples for wall temperature measurement along the heated length. The natural circulation tests will span pressures up to $1 \mathrm{MPa}$, heat fluxes up to $300 \mathrm{~kW} / \mathrm{m}^{2}$, and a wide range of flow rates through manipulation of the test section inlet loss coefficient

The experimental design and conditions described above are likely to address some important aspects of the validation data gap we have identified. For instance, boiling heat transfer data for forced or free convection in a test section geometry of annulus directly match the needs discussed above. Also, this experiment has advantage for code validation in view of the fact that more detailed measurements and a more one-to-one comparison with system codes can be done at much lower cost, compared to the experiment using a rod bundle. 
Table 4. Evaluation matrix for fundamental tests (FT, VR-18 VR-54) in RELAP-7 code V\&V RTM

\begin{tabular}{|c|c|c|c|c|c|c|c|c|c|c|c|c|c|c|c|c|c|c|c|c|c|c|c|c|c|c|c|c|c|c|c|c|c|c|}
\hline & VR-18 & VR-22 & VR-23 & VR-24| & VR-25 & VR-26 & VR-27 & VR-28 & VR-29 & VR-30 & VR-31 & VR-32 & VR-33 & VR-34 & VR-35 & VR-36 V & VR-37V & VR-38 V & VR-39V & VR-40 V & VR-41 & VR-42 & VR-43 & VR-44 & $\mid \mathrm{VR}-45$ & 5 VR-46 & 6 VR-47 & VR-48 & VR-49 & VR-50 & o VR-51 & VR-52 & & 3 VR-54 \\
\hline \multirow{2}{*}{\multicolumn{35}{|c|}{\begin{tabular}{|c|}
$\begin{array}{c}\text { Subcooled Single-Phase } \\
\text { Phenomena }\end{array}$ \\
\end{tabular}}} \\
\hline & & & & & & & & & & & & & & & & & & & & & & & & & & & & & & & & & & \\
\hline $\begin{array}{l}\text { Pressure drop at geometric } \\
\text { discontinuities }\end{array}$ & & & & $v$ & $v$ & & & & & & & & & & & & & & & & & & & & & & & & & & & & & \\
\hline Pressure wave propagation & & & & & & $\mathrm{v}$ & & & & & & & & & & & & & & & & & & & & & & & & & & & & \\
\hline Flow split & & & & & & & & * & & & & & & & & & & & & & & & & & & & & & & & & & & \\
\hline $\begin{array}{l}\text { Convection heat transfer (Forced } \\
\text { and natural) }\end{array}$ & & & & & & & & & * & & & & & & & & & & & & & & & & & & & & & & & & & \\
\hline \multirow{2}{*}{\multicolumn{35}{|c|}{$\begin{array}{l}\text { Natural circulation } \\
\text { Two-Phase Phenomena }\end{array}$}} \\
\hline & & & & & & & & & & & & & & & & & & & & & & & & & & & & & & & & & & \\
\hline Wall to fluid friction & & $\mathrm{v}$ & & & $\mathrm{v}$ & & & & & . & & $\mathrm{v}$ & & & & & & & $\mathrm{v}$ & & & & & & 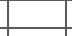 & & & & & $\mathrm{v}$ & & & & \\
\hline $\begin{array}{l}\text { Pressure drop at geometric } \\
\text { discontinuities }\end{array}$ & & & & & v & & & & & & & & & & & & & & & & & & & & & & & & & & & & & \\
\hline $\begin{array}{l}\text { Interphase friction in vertical } \\
\text { flow }\end{array}$ & & & & & $\mathrm{v}$ & & & & & $v$ & & & & & & & & & & & & & & & & & & & & & & & & \\
\hline Phase separation in vertical flow & & & & & & & & & & v & v & & & & & v & & v & & & & v & v & & v & & & & & & & & & \\
\hline $\begin{array}{l}\text { Two-phase mixture level swell } \\
\text { (or level tracking) }\end{array}$ & & & & & & & & & & & $v$ & $v$ & & $\mathrm{v}$ & $\mathrm{v}$ & & & & & & & & & & & & & & & & & & & \\
\hline $\begin{array}{l}\text { Phase separation in horizontal } \\
\text { flow }\end{array}$ & & & & & & & & & & & & $\mathrm{v}$ & & & & & & $\mathrm{v}$ & $\mathrm{v}$ & & & & & & & & & & & $v$ & & & & \\
\hline Phase separation at branches & & & & & & & & & & & & & $*$ & & & & & & & & & & & & & & & & & & & & & \\
\hline Entrainment/de-entrainment & & & & & & & & & & & & & & & & $v$ & $\mathrm{v}$ & & & & & & & & & & & & & & & & & \\
\hline Pressure wave propagation & & & $\mathrm{v}$ & & & & $v$ & & & & & & & & & & & & & & & & & & & & & & & & & & & \\
\hline Flashing & & & & & & & & & & & & $\mathrm{v}$ & & & & & & $\mathrm{v}$ & $v$ & & & & & & & & & & & $v$ & & & & \\
\hline Counter-current flow & & & & & & & & & & & & & & & & & & & & $\mathrm{v}$ & $\mathrm{v}$ & & & & & & & & & & & & & \\
\hline Counter-current flow limitation & & & & & & & & & & & & & & & & & & & & $v$ & $\mathrm{v}$ & & & & & & & & & & & & & \\
\hline \begin{tabular}{|l|} 
Boiling heat transfer \\
\end{tabular} & & & & & & & & & & & & & & & & & & & & & & $\mathrm{v}$ & $v$ & & $v$ & & & & & & & & & \\
\hline Critical heat flux/dryout & & & & & & & & & & & & & & & & & & & & & & $v$ & $v$ & & $\mathrm{v}$ & & & & & & & & & \\
\hline Re-wetting heat transfer & & & & & & & & & & & & & & & & & & & & & & & & $\mathrm{v}$ & & & & & & & & & & \\
\hline $\begin{array}{l}\text { Film boiling/superheating heat } \\
\text { transfer }\end{array}$ & & & & & & & & & & & & & & & & & & & & & & & & & $\mathrm{v}$ & & & & & & & & & \\
\hline $\begin{array}{l}\text { Superheating due to } \\
\text { compression }\end{array}$ & & & & & & & & & & & & & & & & & & & & & & & & & & $v$ & & & & & & & & \\
\hline Radiation heat transfer & & & & & & & & & & & & & & & & & & & & & & & & & & & $v$ & & & & & & & \\
\hline Interphase heat transfer & & & & & & & & & & & & & & & & & & & & & & & & & & & & $\mathrm{v}$ & & & & & & \\
\hline $\begin{array}{l}\text { Condensation heat transfer on } \\
\text { surfaces }\end{array}$ & & & & & & & & & & & & & & & & & & & & & & & & & & & & & $v$ & & & & & \\
\hline Non-condensable gas effects & & & & & & & & & & & & & & & & & & & & & & & & & & & & & & & $\mathrm{v}$ & & & \\
\hline \multirow{2}{*}{\multicolumn{35}{|c|}{$\begin{array}{l}\text { Critical flow, blowdown } \\
\text { Other relevant phenomena }\end{array}$}} \\
\hline & & & & & & & & & & & & & & & & & & & & & & & & & & & & & & & & & & \\
\hline Boron mixing and transport & & & & & & & & & & & & & & & & & & & & & & & & & & & & & & & & & * & \\
\hline \multicolumn{35}{|l|}{\begin{tabular}{|l|} 
Multi-D effect tests \\
Two-Phase Rod Bundle
\end{tabular}} \\
\hline \multicolumn{35}{|l|}{$\begin{array}{l}\text { Two-Phase Rod Bundle } \\
\text { Phenomena }\end{array}$} \\
\hline \multicolumn{35}{|l|}{ 1. Fluid mixing } \\
\hline 2. Spacer grid effects & & & & & & & & & & & & & & & & & & & & & & & & & & & & & & & & & & \\
\hline $\begin{array}{l}\text { 3. Parallel channel instability } \\
\text { (BWR) }\end{array}$ & & & & & & & & & & & & & & & & & & & & & & & & & & & & & & & & & & \\
\hline
\end{tabular}


RELAP-7 Software Verification and Validation Plan: Requirements Traceability Matrix (RTM) Update and Code Verification Strategy

Table 5. Evaluation matrix for separate effect tests (SET, VR-55 VR-77) in RELAP-7 code V\&V RTM

\begin{tabular}{|c|c|c|c|c|c|c|c|c|c|c|c|c|c|c|c|c|c|c|}
\hline & VR-55 & VR-56 & VR-57 & VR-58 & VR-59 & VR-60 & VR-61 & VR-62 & VR-63 & VR-64 & VR-65 & VR-66 & VR-67 & VR-68 & 8 VR-69| & 9 VR-70 & VR-71 & 1 VR-77 \\
\hline \multicolumn{19}{|l|}{$\begin{array}{c}\text { Subcooled Single-Phase } \\
\text { Phenomena }\end{array}$} \\
\hline \multicolumn{19}{|l|}{ Wall to fluid friction } \\
\hline \multicolumn{19}{|l|}{$\begin{array}{l}\text { Pressure drop at geometric } \\
\text { discontinuities }\end{array}$} \\
\hline \multicolumn{19}{|l|}{ Pressure wave propagation } \\
\hline \multicolumn{19}{|l|}{ Flow split } \\
\hline \multicolumn{19}{|l|}{$\begin{array}{l}\text { Convection heat transfer (Forced } \\
\text { and natural) }\end{array}$} \\
\hline \multirow{2}{*}{\multicolumn{19}{|c|}{\begin{tabular}{|l} 
Natural circulation \\
Two-Phase Phenomena
\end{tabular}}} \\
\hline & & & & & & & & & & & & & & & & & & \\
\hline Wall to fluid friction & & & & & & $\mathrm{v}$ & & & & & & & & & & & & \\
\hline $\begin{array}{l}\text { Pressure drop at geometric } \\
\text { discontinuities }\end{array}$ & & & & & & $\mathrm{v}$ & & & & & & & & & & & & \\
\hline $\begin{array}{l}\text { Interphase friction in vertical } \\
\text { flow }\end{array}$ & $\mathrm{v}$ & $\mathrm{v}$ & $\mathrm{v}$ & & & $\mathrm{v}$ & & $\mathrm{v}$ & $\mathrm{v}$ & $\mathrm{v}$ & $\mathrm{v}$ & & & & & & & \\
\hline Phase separation in vertical flow & & $v$ & v & $v$ & & v & $v$ & v & v & v & v & & & & & & & \\
\hline $\begin{array}{l}\text { Two-phase mixture level swell } \\
\text { (or level tracking) }\end{array}$ & $\mathrm{v}$ & $\mathrm{v}$ & & $v$ & & $\mathrm{v}$ & & $\mathrm{v}$ & & $\mathrm{v}$ & & & & & & & & \\
\hline \multicolumn{19}{|l|}{$\begin{array}{l}\text { Phase separation in horizontal } \\
\text { flow }\end{array}$} \\
\hline \multicolumn{19}{|l|}{ Phase separation at branches } \\
\hline Entrainment/de-entrainment & & & & $\mathrm{v}$ & & & & $\mathrm{v}$ & & & $\mathrm{v}$ & & & & & & & \\
\hline \multicolumn{19}{|l|}{ Pressure wave propagation } \\
\hline Flashing & & & & $\mathrm{v}$ & & & & & & & & & & & & & & \\
\hline Counter-current flow & & & & & $\mathrm{v}$ & & $\mathrm{v}$ & & & & & & $\mathrm{v}$ & & & & & \\
\hline Counter-current flow limitation & & & & & $\mathrm{v}$ & & $\mathrm{v}$ & & & & & & $\mathrm{v}$ & & & & & \\
\hline Boiling heat transfer & $\mathrm{v}$ & $\mathrm{v}$ & $\mathrm{v}$ & & & & $\mathrm{v}$ & $\mathrm{v}$ & & $\mathrm{v}$ & & & & & & & & \\
\hline Critical heat flux/dryout & $\mathrm{v}$ & $\mathrm{v}$ & $\mathrm{v}$ & & & & & $\mathrm{v}$ & & $\mathrm{v}$ & & $\mathrm{v}$ & $\mathrm{v}$ & $\mathrm{v}$ & & & & \\
\hline Re-wetting heat transfer & & & $\mathrm{v}$ & & & & $\mathrm{v}$ & $\mathrm{v}$ & & $\mathrm{v}$ & & $\mathrm{v}$ & $\mathrm{v}$ & $\mathrm{v}$ & & & & \\
\hline $\begin{array}{l}\text { Film boiling/superheating heat } \\
\text { transfer }\end{array}$ & $\mathrm{v}$ & $\mathrm{v}$ & $\mathrm{v}$ & & & & & $\mathrm{v}$ & $\mathrm{v}$ & $v$ & & & & & & & & \\
\hline $\begin{array}{l}\text { Superheating due to } \\
\text { compression }\end{array}$ & & & & & & & & & & & & & & & & & & $\mathrm{v}$ \\
\hline \multicolumn{19}{|l|}{ Radiation heat transfer } \\
\hline Interphase heat transfer & & & & & & & & & & & & & & & & & & $\mathrm{v}$ \\
\hline \multicolumn{19}{|l|}{$\begin{array}{l}\text { Condensation heat transfer on } \\
\text { surfaces }\end{array}$} \\
\hline \multicolumn{19}{|l|}{ Non-condensable gas effects } \\
\hline Critical flow, blowdown & & & $\mathrm{v}$ & $\mathrm{v}$ & & & & & & & & & & & & & & \\
\hline \multicolumn{19}{|l|}{ Other relevant phenomena } \\
\hline \multicolumn{19}{|l|}{ Boron mixing and transport } \\
\hline Multi-D effect tests & & & & & & & & & & & & $\mathrm{v}$ & $\mathrm{v}$ & $\mathrm{v}$ & $\mathrm{v}$ & $\mathrm{v}$ & $\mathrm{v}$ & \\
\hline \multicolumn{19}{|l|}{$\begin{array}{l}\text { Two-Phase Rod Bundle } \\
\text { Phenomena }\end{array}$} \\
\hline 1. Fluid mixing & & & & & & & & & & & & & & & & $v$ & & \\
\hline 2. Spacer grid effects & & & & & & & & $\mathrm{v}$ & & & & & & & & & & \\
\hline $\begin{array}{l}\text { 3. Parallel channel instability } \\
\text { (BWR) }\end{array}$ & & & & & & $\mathrm{v}$ & & & & & & & & & & & & \\
\hline
\end{tabular}




\section{RELAP-7 VERIFICATION STRATEGY, PROCEDURE, AND VERIFICATION TEST COVERAGE SUITE}

Motivated by the RELAP-7 IV\&V activity in 2016 [2] and the development progress of RELAP-7 (i.e., Phase II, see Table 1), RELAP-7 V\&V team has recently begun the work for RELAP-7 (independent) verification. The main goal of this independent verification is to find any coding mistakes or subtle errors that may have been overlooked by code developers through the RELAP-7 development. This is an essential procedure to ensure that the source code is free of error, while the validation aims to assess how accurately the "verified" code predicts the real world (see Figure 5). Therefore, the verification must be done in principle prior to any validation tasks for RELAP-7 as well as before the code is distributed for real applications. Another important point is that, as suggested by IEEE Std.1012-2004 [11], the code verification should be performed by personnel who are not involved in the code development activity to maintain the technical independence.

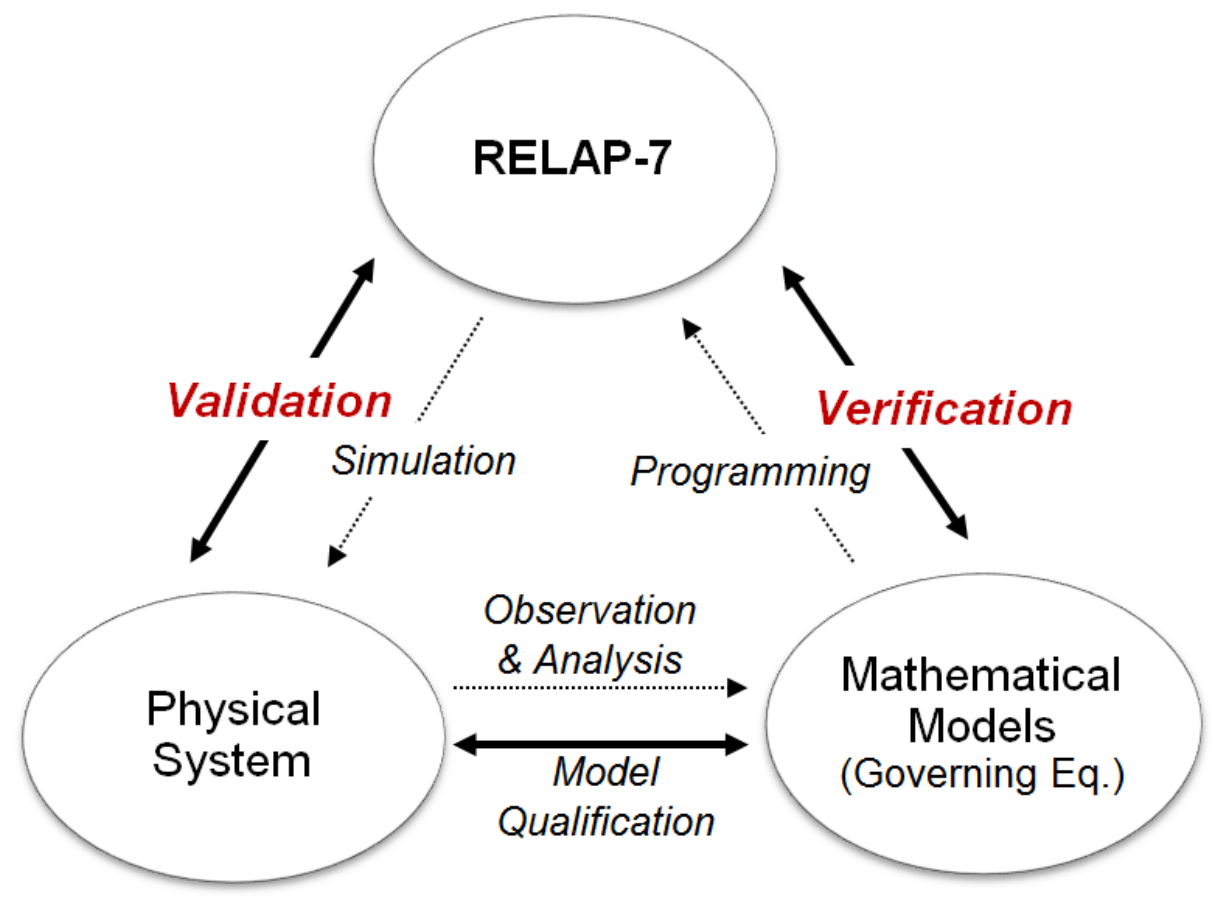

Figure 5. Conceptual schematic for RELAP-7 code verification and validation

In general, there are three different ways of code verification to ensure the correctness of a code that deals with the partial differential equations such as RELAP-7: (i) static code testing, (ii) dynamic code testing, and (iii) formal code testing [12]. Static code testing refers to a test to check the coding consistency in the use of computer language without running the code. General coding mistakes such as variable initialization, function/subroutine naming error or calling statement errors are subject to the static test. Once the static code testing is complete, the next step is dynamic code testing. The dynamic code testing is performed to find coding errors/mistakes via running the code and analyzing the results. Many different kinds of code testing methods fall into this category, e.g., trend test, symmetry test, comparison test, benchmark test, and order-of-accuracy verification test (hereafter, order-verification test). Of them, the most rigorous way of detecting coding errors is using order-verification test. As the last step of code verification, there is formal code testing. The formal code testing is performed in a manner reviewing the source code line-by-line, aiming to search for additional coding mistakes that cannot be detected through either static or dynamic code testing. 
RELAP-7 Software Verification and Validation Plan: Requirements Traceability Matrix (RTM) Update and Code Verification Strategy

For RELAP-7 independent verification, the static code test is assumed complete, and the dynamic code test is underway by RELAP-7 V\&V team. Specifically, RELAP-7 will be verified via the method of order-of-accuracy verification test (or simply order-verification test). The overall procedure for RELAP-7 order-verification is as follows: First, the theoretical order-of-accuracy of the discretization schemes applied to RELAP-7 is identified. Then, a set of test problems (i.e., verification test coverage suite) is designed in which reference solutions (e.g., exact solution) are provided together to eventually compare them with the numerical solutions calculated by the code. Next, for a given test problem a series of code runs is performed while systematically refining the mesh or time step size. The global discretization error is then calculated for each code run by comparing the result with reference solution. Then, the global discretization errors are used to determine the observed order-of-accuracy for a given test problem.

If there is no error in the source code, the theoretical order-of-accuracy for RELAP-7 will match the observed order-of-accuracy. If this is not the case, one must suspect either a coding mistake in the source code or any errors in the test input used for the order-verification test. In any case, if an error is suspected, we have to go through the process to fix it and repeat the above-mentioned procedure until the results of theoretical and observed orders-of-accuracy match. In case that any error is suspected in the source code, the result should be reported to the RELAP-7 developers for trouble shooting. This implies that, during the work for RELAP-7 IV\&V, although the technical independence is required [11], significant level of communication is necessary with RELAP-7 developers because the code is still evolving at the moment. However, the communication should be made within the prescribed procedure and scope. The overall procedure that has been established for the RELAP-7 independent verification is shown in Figure 6.

As for the mesh (or time step) refinement for code verification, three different ways can be applied, i.e., (i) direct approach, (ii) decoupled approach, and (iii) iterated Richardson extrapolation [13]. These concepts are especially important for the verification of a code that conducts transient calculations like RELAP-7. In principle, the mesh and time step refinement should be performed such that the spatial and temporal discretization errors are decreased at the same factor (direct approach). Otherwise, the correct convergence rate of the discretization error cannot be computed. Each refinement method is illustrated in Figure 7. To easily isolate the coding mistake or to avoid the high computational cost, decoupled approach [14] or iterated Richarson extrapolation [13] has been preferred by the previous researchers. Note that the exact solution is not required for the use of iterated Richardson extrapolation. 
RELAP-7 Software Verification and Validation Plan: Requirements Traceability Matrix (RTM) Update and Code Verification Strategy



Figure 6. Independent code verification procedure for RELAP-7 
RELAP-7 Software Verification and Validation Plan: Requirements Traceability Matrix (RTM) Update and Code Verification Strategy

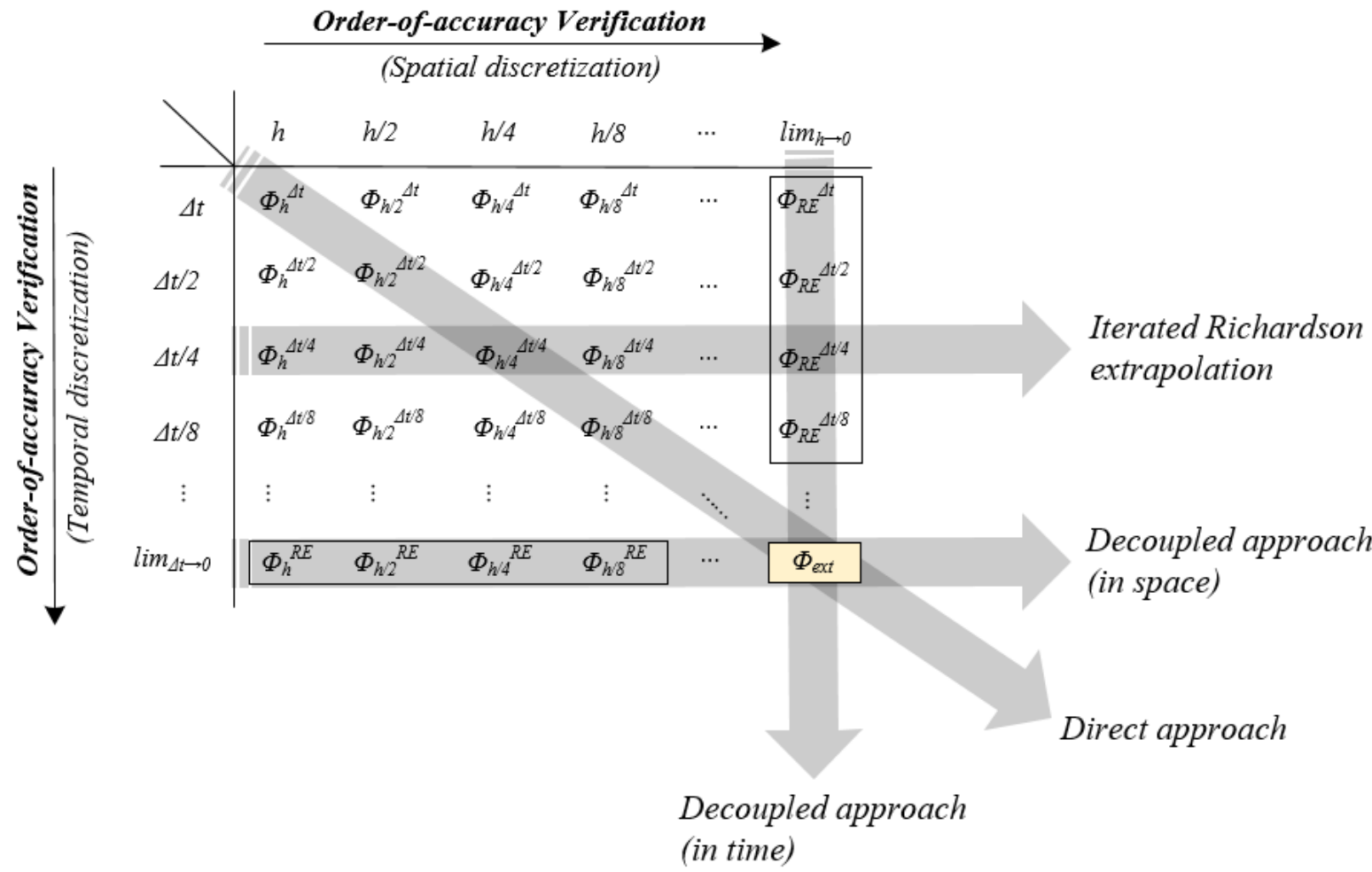

Figure 7. Three refinement strategies for the order-verification test

Table 6 shows the verification test coverage suite that will be used to verify the hydrodynamic (or flow) equations implemented into RELAP-7. The order-verification test for the pipe component will be performed based on the test problems given in this table. Table 6 is specially designed such that the code can be verified for all the options available in RELAP-7 for the pipe component (e.g., boundary conditions, stabilization schemes). Considering that the theoretical order-of-accuracy can be achieved only when there is no error in any options selected for each test, the existence of coding errors can be thoroughly examined using this table. The similar test plan should be established for the other major components used in RELAP-7 (e.g., branch) and for the heat equations. In principle, the exact solution will be used as reference solution in estimating the global discretization error, but fine mesh numerical solution will be used instead if the exact solution is not available for a given test problem. It is noted that the specific test plan shown in Table 6 may change as the RELAP-7 development or IV\&V work and/or plan progresses.

Given the strategy and procedure described above, the actual work for order-verification was performed using RELAP-7 for the Task No. 1 (hydrostatic test) in Table 6. The first-order stabilization scheme was applied with solid-wall boundary conditions on both ends of vertical pipe. The result is shown in Figure 8, which indicates that the observed order-of-accuracy converges to the theoretical orderof-accuracy as the mesh size is refined. This verifies that there is no coding error for the flow equations as well as the RELAP-7 options (e.g., boundary conditions, stabilization scheme) used for the Task No. 1. The "RELAP-7 Test Status" in the code V\&V RTM (i.e., VR-4 VR-7) will be able to be marked as "tested" after all the tests listed in the verification coverage test suite is completed successfully. Note that Table 6 is only for verifying the hydrodynamic equations applied to the pipe component in RELAP-7. The similar verification test coverage suite should be created in the future for verifying the correctness of heat conduction equations (1D and 2D) and the other components implemented into RELAP-7. 
RELAP-7 Software Verification and Validation Plan: Requirements Traceability Matrix (RTM) Update and Code Verification Strategy

Table 6. RELAP-7 verification test coverage suite for flow problems (pipe component)

\begin{tabular}{|c|c|c|c|c|c|c|c|c|c|}
\hline \multirow{2}{*}{$\begin{array}{l}\text { Task } \\
\text { No. }\end{array}$} & \multirow{2}{*}{$\begin{array}{c}\text { Title } \\
\text { (Req. No for } \\
\text { RTM) }\end{array}$} & \multirow{2}{*}{$\begin{array}{c}\text { Test type } \\
\text { (1D, } \\
\text { std/trn) }\end{array}$} & \multirow{2}{*}{$\begin{array}{c}\text { Geom. } \\
\text { (Component) }\end{array}$} & \multicolumn{3}{|c|}{ B.C } & \multirow{2}{*}{$\begin{array}{c}\text { Time } \\
\text { integration }\end{array}$} & \multirow[b]{2}{*}{ Time stepper } & \multirow{2}{*}{$\begin{array}{c}\text { Stabilization } \\
\text { method }\end{array}$} \\
\hline & & & & $\begin{array}{l}\text { Left } \\
\text { (inlet) }\end{array}$ & $\begin{array}{l}\text { Right } \\
\text { (outlet) }\end{array}$ & $\begin{array}{l}\text { Reversible } \\
\text { flow option }\end{array}$ & & & \\
\hline 1 & \multirow{4}{*}{$\begin{array}{l}\text { Single-phase test } \\
\text { without flow } \\
\text { (VR-1, 4) }\end{array}$} & \multirow{4}{*}{$\begin{array}{l}\text { 1D, std } \\
\text { (Single- } \\
\text { phase) }\end{array}$} & \multirow{4}{*}{$\begin{array}{c}\text { Pipe } \\
\text { (vertical) }\end{array}$} & $\begin{array}{l}\text { Solid } \\
\text { Wall }\end{array}$ & $\begin{array}{l}\text { Solid } \\
\text { Wall }\end{array}$ & \multirow{4}{*}{ No } & \multirow{4}{*}{$\mathrm{BDF} 2$} & \multirow{4}{*}{ AdaptiveDT } & $\begin{array}{c}\text { evm } \\
\text { (1st order) }\end{array}$ \\
\hline 2 & & & & $\begin{array}{l}\text { Solid } \\
\text { Wall }\end{array}$ & $\begin{array}{l}\text { Solid } \\
\text { Wall }\end{array}$ & & & & $\begin{array}{c}\text { evm } \\
\text { (2nd order) }\end{array}$ \\
\hline 3 & & & & Inlet & Outlet & & & & $\begin{array}{c}\text { evm } \\
\text { (1st order) }\end{array}$ \\
\hline 4 & & & & TDV & TDV & & & & $\begin{array}{c}\text { evm } \\
\text { (1st order) }\end{array}$ \\
\hline 5 & \multirow{3}{*}{$\begin{array}{l}\text { Two-phase test } \\
\text { without flow } \\
\text { (VR-2,4) }\end{array}$} & \multirow{3}{*}{$\begin{array}{c}\text { 1D, std } \\
\text { (two-phase) }\end{array}$} & \multirow{3}{*}{$\begin{array}{c}\text { Pipe } \\
\text { (vertical) }\end{array}$} & $\begin{array}{l}\text { Solid } \\
\text { Wall }\end{array}$ & $\begin{array}{l}\text { Solid } \\
\text { Wall }\end{array}$ & No & $\mathrm{BDF} 2$ & \multirow{3}{*}{ AdaptiveDT } & $\begin{array}{c}\text { evm } \\
\text { (1st order) }\end{array}$ \\
\hline 6 & & & & $\begin{array}{l}\text { Solid } \\
\text { Wall }\end{array}$ & $\begin{array}{l}\text { Solid } \\
\text { Wall }\end{array}$ & No & $\mathrm{BDF} 2$ & & $\begin{array}{c}\text { evm } \\
\text { (2nd order) }\end{array}$ \\
\hline 7 & & & & TDV & TDV & No & BDF2 & & $\begin{array}{c}\text { evm } \\
\text { (1st order) }\end{array}$ \\
\hline 8 & \multirow{6}{*}{$\begin{array}{l}\text { Single-phase test } \\
\text { with flow } \\
\text { (VR-4) } \\
\text { B.C Tests }\end{array}$} & $\begin{array}{l}\text { 1D, std } \\
\text { (Single- } \\
\text { phase) }\end{array}$ & $\begin{array}{c}\text { Pipe } \\
\text { (horizontal) }\end{array}$ & $\begin{array}{l}\text { Inlet } \\
\text { (vel, } \\
\text { mfr) }\end{array}$ & $\begin{array}{c}\text { Outlet } \\
(\mathrm{P}=1 \\
\text { atm })\end{array}$ & \multirow{6}{*}{ No } & \multirow{6}{*}{ BDF2 } & FixedTimeStep & $\begin{array}{c}\text { evm } \\
\text { (1st order) }\end{array}$ \\
\hline 9 & & $\begin{array}{l}\text { 1D, trn } \\
\text { (Single- } \\
\text { phase) }\end{array}$ & $\begin{array}{c}\text { Pipe } \\
\text { (horizontal) }\end{array}$ & $\begin{array}{l}\text { Inlet } \\
\text { (vel, } \\
\text { mfr) }\end{array}$ & $\begin{array}{c}\text { Outlet } \\
(\mathrm{P}=1 \\
\mathrm{atm})\end{array}$ & & & FixedTimeStep & $\begin{array}{c}\text { evm } \\
\text { (1st order) }\end{array}$ \\
\hline 10 & & $\begin{array}{l}\text { 1D, std } \\
\text { (Single- } \\
\text { phase) }\end{array}$ & $\begin{array}{c}\text { Pipe } \\
\text { (horizontal) }\end{array}$ & $\begin{array}{l}\text { Inlet } \\
\text { (vel, } \\
\text { mfr) }\end{array}$ & $\begin{array}{l}\text { TDV } \\
(\mathrm{P}=1 \\
\mathrm{atm})\end{array}$ & & & FixedTimeStep & $\begin{array}{c}\text { evm } \\
\text { (1st order) }\end{array}$ \\
\hline 11 & & $\begin{array}{l}\text { 1D, std } \\
\text { (Single- } \\
\text { phase) }\end{array}$ & $\begin{array}{c}\text { Pipe } \\
\text { (horizontal) }\end{array}$ & $\begin{array}{c}\text { TDJ } \\
\text { (Inflow) }\end{array}$ & $\begin{array}{c}\text { Outlet } \\
(\mathrm{P}=1 \\
\mathrm{atm})\end{array}$ & & & FixedTimeStep & $\begin{array}{c}\text { evm } \\
\text { (1st order) }\end{array}$ \\
\hline 12 & & $\begin{array}{l}\text { 1D, std } \\
\text { (Single- } \\
\text { phase) }\end{array}$ & $\begin{array}{c}\text { Pipe } \\
\text { (horizontal) }\end{array}$ & Inlet & $\begin{array}{c}\text { Outlet } \\
(\mathrm{P}=1 \\
\text { atm })\end{array}$ & & & FixedTimeStep & $\begin{array}{c}\text { evm } \\
\text { (2nd order) }\end{array}$ \\
\hline 13 & & $\begin{array}{l}\text { 1D, trn } \\
\text { (Single- } \\
\text { phase) }\end{array}$ & $\begin{array}{c}\text { Pipe } \\
\text { (vertical) }\end{array}$ & Inlet & $\begin{array}{l}\text { Outlet } \\
(\mathrm{P}=1 \\
\text { atm })\end{array}$ & & & FixedTimeStep & $\begin{array}{c}\text { evm } \\
\text { (1st order) }\end{array}$ \\
\hline 14 & \multirow{5}{*}{$\begin{array}{l}\text { Two-phase test } \\
\text { with flow } \\
\text { (VR-3) } \\
\text { B.C Tests }\end{array}$} & $\begin{array}{l}\text { 1D, trn } \\
\text { (Two- } \\
\text { phase) }\end{array}$ & \multirow{2}{*}{$\begin{array}{c}\text { Pipe } \\
\text { (horizontal) }\end{array}$} & Inlet & $\begin{array}{l}\text { Outlet } \\
(\mathrm{P}=1 \\
\text { atm })\end{array}$ & \multirow{5}{*}{ No } & \multirow{5}{*}{ BDF2 } & \multirow{5}{*}{ FixedTimeStep } & $\begin{array}{c}\text { evm } \\
\text { (1st order) }\end{array}$ \\
\hline 15 & & $\begin{array}{l}\text { 1D, trn } \\
\text { (Two- } \\
\text { phase) }\end{array}$ & & $\begin{array}{c}\text { Inlet } \\
\text { (Inflow) }\end{array}$ & $\begin{array}{l}\text { TDV } \\
(\mathrm{P}=1 \\
\mathrm{atm})\end{array}$ & & & & $\begin{array}{c}\text { evm } \\
\text { (1st order) }\end{array}$ \\
\hline 16 & & $\begin{array}{l}\text { 1D, trn } \\
\text { (Two- } \\
\text { phase) }\end{array}$ & $\begin{array}{c}\text { Pipe } \\
\text { (horizontal) }\end{array}$ & $\begin{array}{c}\text { TDJ } \\
\text { (Inflow) }\end{array}$ & $\begin{array}{c}\text { Outlet } \\
(\mathrm{P}=1 \\
\mathrm{atm})\end{array}$ & & & & $\begin{array}{c}\text { evm } \\
\text { (1st order) }\end{array}$ \\
\hline 17 & & $\begin{array}{l}1 \mathrm{D}, \operatorname{trn} \\
\text { (Two- } \\
\text { phase) }\end{array}$ & $\begin{array}{c}\text { Pipe } \\
\text { (horizontal) }\end{array}$ & Inlet & $\begin{array}{c}\text { Outlet } \\
(\mathrm{P}=1 \\
\text { atm })\end{array}$ & & & & $\begin{array}{c}\text { evm } \\
\text { (2nd order) }\end{array}$ \\
\hline 18 & & $\begin{array}{l}\text { 1D, trn } \\
\text { (Two- } \\
\text { phase) }\end{array}$ & $\begin{array}{c}\text { Pipe } \\
\text { (vertical) }\end{array}$ & Inlet & $\begin{array}{l}\text { Outlet } \\
(\mathrm{P}=1 \\
\text { atm })\end{array}$ & & & & $\begin{array}{c}\text { evm } \\
\text { (1st order) }\end{array}$ \\
\hline 19 & $\begin{array}{l}\text { Single-phase test } \\
\text { with flow } \\
\text { (VR-6) }\end{array}$ & $\begin{array}{l}1 \mathrm{D}, \text { trn } \\
\text { (Single- }\end{array}$ & $\begin{array}{c}\text { Pipe } \\
\text { (horizontal) }\end{array}$ & Inlet & $\begin{array}{l}\text { Outlet } \\
(\mathrm{P}=1\end{array}$ & No & BDF2 & FixedTimeStep & SUPG \\
\hline 20 & $\begin{array}{c}\text { Stab. Scheme } \\
\text { Tests }\end{array}$ & phase) & & & atm) & & & & LAPIDUS \\
\hline
\end{tabular}


RELAP-7 Software Verification and Validation Plan: Requirements Traceability Matrix (RTM) Update and Code Verification Strategy

\begin{tabular}{|c|c|c|c|c|c|c|c|c|c|}
\hline 21 & \multirow{2}{*}{$\begin{array}{l}\text { Two-phase test } \\
\text { with flow } \\
\text { (VR-6) } \\
\text { Stab. Scheme } \\
\text { Tests }\end{array}$} & \multirow{2}{*}{$\begin{array}{l}\text { 1D, trn } \\
\text { (Two- } \\
\text { phase) }\end{array}$} & \multirow{2}{*}{$\begin{array}{c}\text { Pipe } \\
\text { (horizontal) }\end{array}$} & \multirow{2}{*}{ Inlet } & \multirow{2}{*}{$\begin{array}{l}\text { Outlet } \\
(\mathrm{P}=1 \\
\mathrm{atm})\end{array}$} & \multirow{2}{*}{ No } & \multirow{2}{*}{$\mathrm{BDF} 2$} & \multirow{2}{*}{ FixedTimeStep } & SUPG \\
\hline 22 & & & & & & & & & LAPIDUS \\
\hline 23 & \multirow{2}{*}{$\begin{array}{l}\text { Single-phase test } \\
\text { with flow } \\
\text { (VR-7) } \\
\text { Temporal } \\
\text { Scheme Tests }\end{array}$} & \multirow{2}{*}{$\begin{array}{l}1 \mathrm{D}, \text { trn } \\
\text { (Single- } \\
\text { phase) }\end{array}$} & \multirow{2}{*}{$\begin{array}{c}\text { Pipe } \\
\text { (horizontal) }\end{array}$} & \multirow{2}{*}{ Inlet } & \multirow{2}{*}{$\begin{array}{l}\text { Outlet } \\
(\mathrm{P}=1 \\
\text { atm) }\end{array}$} & \multirow{2}{*}{ No } & $\begin{array}{l}\text { Backward } \\
\text { Euler }\end{array}$ & \multirow{2}{*}{ FixedTimeStep } & $\begin{array}{c}\text { evm } \\
\text { (1st order) }\end{array}$ \\
\hline 24 & & & & & & & $\mathrm{C}-\mathrm{N}$ & & $\begin{array}{c}\text { evm } \\
\text { (1st order) }\end{array}$ \\
\hline 25 & \multirow{2}{*}{$\begin{array}{l}\text { Two-phase test } \\
\text { with flow } \\
\text { (VR-7) } \\
\text { Temporal } \\
\text { Scheme Tests }\end{array}$} & \multirow{2}{*}{$\begin{array}{l}\text { 1D, trn } \\
\text { (Two- } \\
\text { phase) }\end{array}$} & \multirow{2}{*}{$\begin{array}{c}\text { Pipe } \\
\text { (horizontal) }\end{array}$} & \multirow{2}{*}{ Inlet } & \multirow{2}{*}{$\begin{array}{l}\text { Outlet } \\
(\mathrm{P}=1 \\
\mathrm{atm})\end{array}$} & \multirow{2}{*}{ No } & $\begin{array}{c}\text { Backward } \\
\text { Euler }\end{array}$ & \multirow{2}{*}{ FixedTimeStep } & $\begin{array}{c}\text { evm } \\
\text { (1st order) }\end{array}$ \\
\hline 26 & & & & & & & C-N & & $\begin{array}{c}\text { evm } \\
\text { (1st order) }\end{array}$ \\
\hline
\end{tabular}

[Abbreviation] std: steady test, trn: transient test, evm: entropy viscosity method, BDF: , vel: velocity, mfr: mass flow rate, $\mathrm{C}-\mathrm{N}$ : Crank-Nicolson method, TDV: time-dependent volume, P: pressure

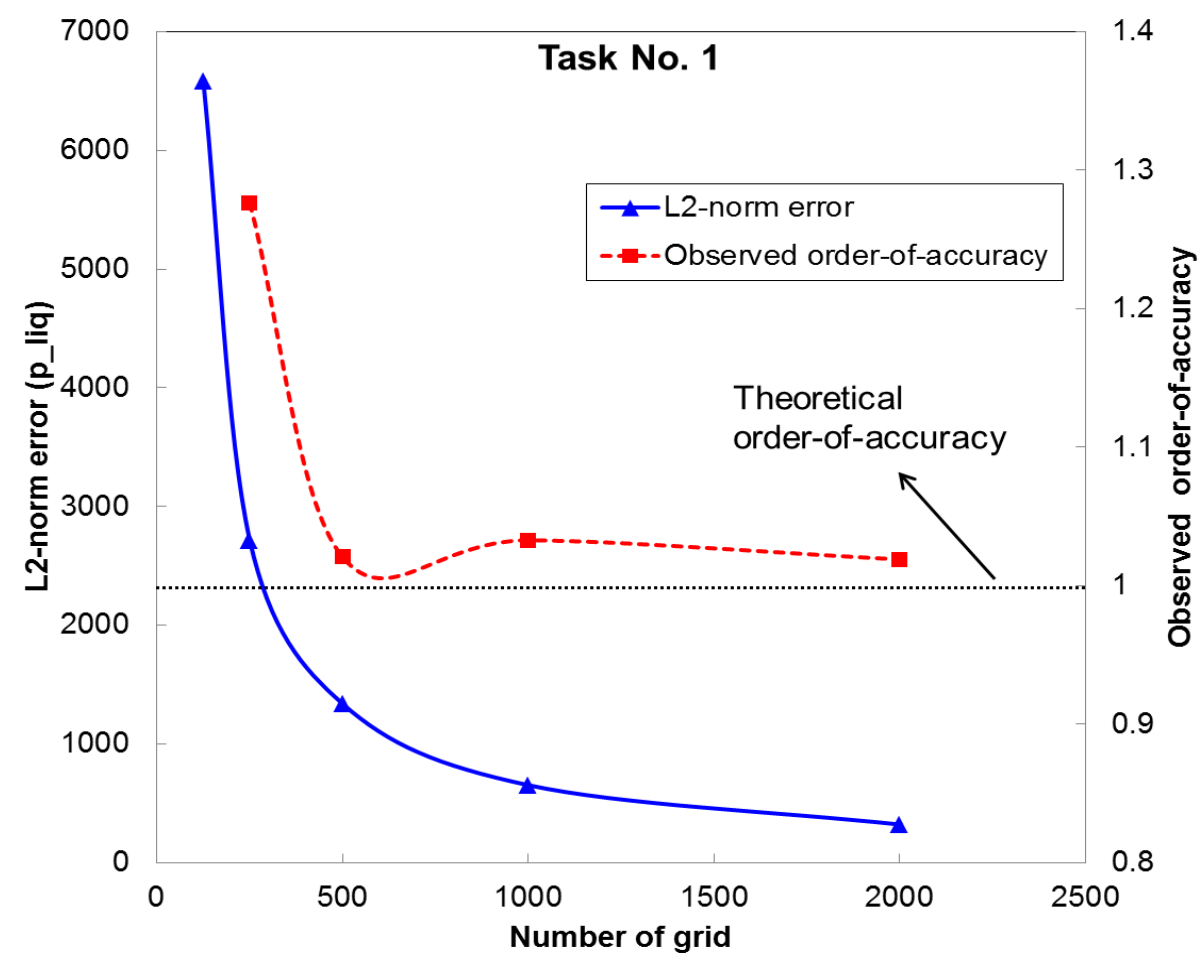

Figure 8. Order-of-accuracy test result for Task No. 1 using RELAP-7 


\section{SUMMARY AND CONCLUSIONS}

This document describes the recent work in RELAP-7 SVVP. The RELAP-7 RTM has been updated in three aspects, i.e., (i) adding the validation requirement items, (ii) rearranging the requirement items, and (iii) introducing the classifier to better define the RELAP-7 V\&V status. Also, from the perspective of nuclear system code validation, we have identified the areas where the validation data is particularly lacking. Specifically, using the RELAP-7 RTM evaluation matrices, six items from the list of LWR safety-relevant phenomena were identified as validation data gaps. Also, the experimental effort of UIUC, supported by the NEUP program, is believed to be valuable in the context of reducing the validation data gaps. Lastly, RELAP-7 V\&V team has established the code verification plan in response to the needs revealed from the previous RELAP-7 IV\&V activities. The code verification method, procedure, and verification test coverage suite discussed in this document will be applied to the future work for the RELAP-7 independent verification. 
RELAP-7 Software Verification and Validation Plan: Requirements Traceability Matrix (RTM) Update and Code Verification Strategy

\section{REFERENCES}

1. $\quad$ Zhang, H., et al., Resource Loaded Development Schedule for RELAP-7. 2017, Tech. Rep. INL/LTD-17-40858, Idaho National Laboratory, USA.

2. Yoo, J. and Y.J. Choi, Additional Model Datasets and Results to Accelerate the Verification and Validation of RELAP-7. 2016, Idaho National Laboratory (INL), Idaho Falls, ID (United States).

3. Yoo, J., Y.-J. Choi, and C.L. Smith, RELAP-7 Software Verification and Validation Plan Requirements Traceability Matrix (RTM) Part 2: Code Assessment Strategy, Procedure, and RTM Update. 2016 Tech. Rep. INL/EXT-16-40015, Idaho National Laboratory, USA.

4. Choi, Y.J., J. Yoo, and C.L. Smith, RELAP-7 Software Verification and Validation Plan: Requirements Traceability Matrix (RTM) Part 1-Physics and numerical methods. 2015, Idaho National Laboratory (INL), Idaho Falls, ID (United States).

5. No, H.C., et al., Korean Development of Advanced Thermal-Hydraulic Codes for Water Reactors and Htgrs: Space and Gamma. Nuclear Technology, 2013. 181(1): p. 24-43.

6. EPRI, Data Sources for Capability Assessments of Next Generation Safety Analysis Codes. 2014, EPRI: Palo Alto, CA, USA.

7. Aksan, N., et al., Separate effects test matrix for thermal-hydraulic code validation: phenmena characterisation and selection of facilities and tests. 1993.

8. IAEA Safety Report Series No. 52 (2008). Best estimate safety analysis for nuclear power plants: uncertainty evaluation. IAEA, Vienna.

9. OECD/CSNI, Proceedings of the OECD/CSNI workshop on transient thermal-hydraulic and neutronic codes requirements. NEA/CSNI/R(97)4. 1996.

10. RELAP5-3D Code Manual Volume IV: Models and Correlations. 2005: Idaho National Laboratory, Idaho Falls, Idaho, USA.

11. Society, I.C., IEEE Standard for Software Verification and Validation. 2004: New York, NY10016-5997, USA.

12. Knupp, P. and K. Salari, Verification of computer codes in computational science and engineering. 2002: CRC Press.

13. Etienne, S., A. Garon, and D. Pelletier. Code verification for unsteady flow simulations with high order time-stepping schemes. in 47th AIAA Aerospace Sciences Meeting including The New Horizons Forum and Aerospace Exposition. 2009.

14. Salari, K. and P. Knupp, Code verification by the method of manufactured solutions. 2000, Sandia National Labs., Albuquerque, NM (US); Sandia National Labs., Livermore, CA (US). 


\section{APPENDIX A. RELAP-7 GENERAL RTM (AS OF 2017)}

\begin{tabular}{|c|c|c|c|c|c|}
\hline $\operatorname{Req} \#$ & Category & Requirement Specification & $\begin{array}{c}\text { Modification } \\
\text { Date } \\
(\mathbf{m m} / \mathbf{d d} / \mathbf{y y y y})\end{array}$ & Code V\&V RTM No. & RELAP-7 Status \\
\hline GR-1 & \multirow{5}{*}{$\begin{array}{l}\text { Reactor Types \& } \\
\text { System Designs }\end{array}$} & $\begin{array}{l}\text { Capability of simulating } \\
\text { various LWR designs such as } \\
\text { PWR and BWR }\end{array}$ & $9 / 30 / 2015$ & $\begin{array}{l}\text { All test cases falling into PWR } \\
\text { or BWR category in Code } \\
\text { V\&V RTM. }\end{array}$ & $\begin{array}{l}\text { Sample Test- } 45 \text { for } \\
\text { BWR (HEM model) } \\
\text { Sample Test-152 } \\
\text { for PWR (TMI } \\
\text { loop) }\end{array}$ \\
\hline GR-2 & & $\begin{array}{l}\text { Capability of simulating } \\
\text { various PWR designs (i.e., } \\
\text { Westinghouse, Combustion } \\
\text { Engineering, and } \\
\text { Babcock\&Wilcox) }\end{array}$ & $9 / 30 / 2015$ & $\begin{array}{l}\text { All test cases falling into PWR } \\
\text { or PWR (B\&W) category in } \\
\text { Code V\&V RTM. }\end{array}$ & $\begin{array}{l}\text { PWR cores are } \\
\text { tested but not } \\
\text { compared for } \\
\text { different } \\
\text { manufactures }\end{array}$ \\
\hline GR-3 & & $\begin{array}{l}\text { Capability of simulating } \\
\text { various containment design } \\
\text { influencing LOCA simulation }\end{array}$ & $9 / 30 / 2015$ & - & Not tested \\
\hline GR-4 & & $\begin{array}{l}\text { Capability of simulating } \\
\text { various ECCS design } \\
\text { influencing LOCA simulation } \\
\text { (accumulators, safety } \\
\text { injection systems such as } \\
\text { UPI, cold-leg/hot-leg } \\
\text { injection) }\end{array}$ & $9 / 30 / 2015$ & VR-61, 62, 66-68, 105 & Not tested \\
\hline GR-5 & & $\begin{array}{l}\text { Capability of modeling } \\
\text { various plant components and } \\
\text { systems for non-LOCA } \\
\text { simulation }\end{array}$ & 9/30/2015 & $\begin{array}{l}\text { All non-LOCA tests included } \\
\text { in Code V\&V RTM can be } \\
\text { used to demonstrate this } \\
\text { capability. }\end{array}$ & Not tested \\
\hline GR-6 & \multirow{9}{*}{$\begin{array}{c}\text { T/H System } \\
\text { Safety Analysis } \\
\text { (Design- and } \\
\text { Licensing-Basis } \\
\text { Transients/Accid } \\
\text { ents) }\end{array}$} & LBLOCA analysis capability & 9/30/2015 & $\begin{array}{l}\text { SET: VR-57-59, 61-64, 66-68 } \\
\text { IET/PT: VR-84, 89, } 105\end{array}$ & Not tested \\
\hline GR-7 & & SBLOCA analysis capability & 9/30/2015 & $\begin{array}{l}\text { SET: VR-55 } \\
\text { IET/PT: VR-83, 90, } 132\end{array}$ & Not tested \\
\hline GR-8 & & $\begin{array}{l}\text { Capability of simulating } \\
\text { excessive heat transfer events } \\
\text { (non-LOCA) }\end{array}$ & $9 / 30 / 2015$ & VR-93 & Not tested \\
\hline GR-9 & & $\begin{array}{l}\text { Capability of simulating loss } \\
\text { of heat transfer events (non- } \\
\text { LOCA) }\end{array}$ & $9 / 30 / 2015$ & $\begin{array}{l}\text { VR- 91, 92, 96, 98, 101-103, } \\
106,107,110,111,114,117, \\
118,121,122-125,127,130, \\
134,135,137\end{array}$ & Not tested \\
\hline GR-10 & & $\begin{array}{l}\text { Capability of simulating loss } \\
\text { of flow events (non-LOCA) }\end{array}$ & $9 / 30 / 2015$ & VR-92, 110, 124, 125, 137 & Not tested \\
\hline GR-11 & & $\begin{array}{l}\text { Capability of simulating } \\
\text { increase/decrease in reactor } \\
\text { coolant inventory events } \\
\text { (non-LOCA) }\end{array}$ & $9 / 30 / 2015$ & - & Not tested \\
\hline GR-12 & & $\begin{array}{l}\text { Capability of simulating } \\
\text { Station Blackout (SBO) and } \\
\text { its consequence }\end{array}$ & $9 / 30 / 2016$ & VR-104, 121 & Not tested \\
\hline GR-13 & & $\begin{array}{l}\text { Capability of simulating } \\
\text { BWR stability }\end{array}$ & $9 / 30 / 2016$ & VR-108 & Not tested \\
\hline GR-14 & & $\begin{array}{l}\text { Capability of simulating } \\
\text { ATWS transients }\end{array}$ & 9/30/2016 & VR-88, 96 & Not tested \\
\hline GR-15 & & $\begin{array}{l}\text { Generate physics parameters } \\
\text { for reactor kinetics model in } \\
\text { system code }\end{array}$ & $9 / 30 / 2015$ & - & Sample Test 65-67 \\
\hline
\end{tabular}


RELAP-7 Software Verification and Validation Plan: Requirements Traceability Matrix (RTM) Update and Code Verification Strategy

\begin{tabular}{|c|c|c|c|c|c|}
\hline GR-16 & \multirow{7}{*}{$\begin{array}{l}\text { Multi-physics } \\
\text { Analysis } \\
\text { (Reactor kinetics, } \\
\text { fuel components } \\
\text { behavior, } \\
\text { chemical } \\
\text { reactions, etc.) }\end{array}$} & $\begin{array}{l}\text { Capability of coupled } \\
\text { simulation with neutronics } \\
\text { code } \\
\text { (to reflect a reactivity } \\
\text { feedback with } 1 \mathrm{D}, \text { multi-D } \\
\text { core power calculation) }\end{array}$ & $9 / 30 / 2016$ & - & Not tested \\
\hline GR-17 & & $\begin{array}{l}\text { Capability of coupled } \\
\text { simulation for } \\
\text { fluid/mechanical interaction } \\
\text { analysis (e.g., water hammer, } \\
\text { LOCA-load analysis) }\end{array}$ & $9 / 30 / 2016$ & - & Not tested \\
\hline GR-18 & & $\begin{array}{l}\text { Capability of coupled } \\
\text { simulation for T/H effect on } \\
\text { structural integrity (e.g., PTS) }\end{array}$ & $9 / 30 / 2016$ & - & Not tested \\
\hline GR-19 & & $\begin{array}{l}\text { Capability of coupled } \\
\text { simulation with fuel } \\
\text { performance code such as } \\
\text { BISON } \\
\text { (to reflect the feedback from } \\
\text { mechanical/ thermal behavior } \\
\text { of fuel pellet, gap, and } \\
\text { cladding depending on reactor } \\
\text { conditions) }\end{array}$ & $9 / 30 / 2015$ & - & Not tested \\
\hline GR-20 & & $\begin{array}{l}\text { Capability of simulating } \\
\text { chemical effect (e.g., } \\
\text { localized corrosion, CRUD) }\end{array}$ & $9 / 30 / 2015$ & - & Not tested \\
\hline GR-21 & & $\begin{array}{l}\text { Capability of simulating } \\
\text { containment analysis (e.g., } \\
\text { FP, aerosol behavior) }\end{array}$ & $9 / 30 / 2015$ & - & Not tested \\
\hline GR-22 & & $\begin{array}{l}\text { Capability of simulating } \\
\text { radiological consequence } \\
\text { analysis }\end{array}$ & $9 / 30 / 2015$ & - & Not tested \\
\hline GR-23 & \multirow{2}{*}{$\begin{array}{l}\text { Multi-D \& Multi- } \\
\text { scale Analysis }\end{array}$} & $\begin{array}{l}\text { Capability of simulating } \\
\text { multi-dimensional fluid flow } \\
\text { (e.g., PWR reflood } \\
\text { phenomena after LOCA) }\end{array}$ & $9 / 30 / 2015$ & $\begin{array}{l}\text { SET: VR-66-71 } \\
\text { IET/PT: VR-105, } 138\end{array}$ & Not tested \\
\hline GR-24 & & $\begin{array}{l}\text { Capability of simulating } \\
\text { multi-dimensional fluid flow } \\
\text { at microscale level of detail } \\
\text { (e.g., flashing, critical flow, } \\
\text { boiling, etc.) }\end{array}$ & $9 / 30 / 2015$ & - & Not tested \\
\hline GR-25 & $\begin{array}{c}\text { Integrated/Impro } \\
\text { ved Uncertainty } \\
\text { Analysis }\end{array}$ & $\begin{array}{l}\text { Incorporating uncertainty } \\
\text { quantification process into an } \\
\text { integral part of the simulation } \\
\text { (e.g., coupling with RAVEN) }\end{array}$ & $9 / 30 / 2016$ & - & Not tested \\
\hline
\end{tabular}


APPENDIX B. RELAP-7 SPECIFIC RTM (AS OF 2017)

\begin{tabular}{|c|c|c|c|c|c|}
\hline Req \# & Category & Requirement Specification & $\begin{array}{l}\text { Modification } \\
\text { Date } \\
(\mathbf{m m} / \mathbf{d d} / \mathbf{y y y y})\end{array}$ & Verification/Action Item & RELAP-7 Status \\
\hline SR-1 & \multirow{7}{*}{$\begin{array}{l}\text { Computer } \\
\text { Science \& } \\
\text { Software } \\
\text { Architecture }\end{array}$} & $\begin{array}{l}\text { Use of the most advanced } \\
\text { computer science technology } \\
\text { (both computing power and } \\
\text { numerical solvers) to } \\
\text { optimize both accuracy and } \\
\text { simulation speed }\end{array}$ & $9 / 30 / 2015$ & $\begin{array}{l}\text { Descritization scheme } \\
\text { Time integration method } \\
\text { Matrix solver } \\
\text { Parallel computation } \\
\text { capability }\end{array}$ & $\begin{array}{l}\text { Written with C++. } \\
\text { Capable of Multi-scale } \\
\text { time integration, PCICE } \\
\text { (operator split), JFNK } \\
\text { (implicit nonlinear } \\
\text { Newton method), and a } \\
\text { point implicit method } \\
\text { (long duration } \\
\text { transients). New pipe } \\
\text { network algorithm based } \\
\text { upon Mortar FEM } \\
\text { (Lagrange multipliers). } \\
\text { Ability to couple to } \\
\text { multi-dimensional } \\
\text { reactor simulators }\end{array}$ \\
\hline SR-2 & & $\begin{array}{l}\text { Numerically robust and } \\
\text { reliable (e.g., Need to check if } \\
\text { it is not subject to failure as a } \\
\text { result of numerical methods) }\end{array}$ & $9 / 30 / 2015$ & $\begin{array}{l}\text { Numerical stability test } \\
\text { Steady-state initialization } \\
\text { test }\end{array}$ & Not tested \\
\hline SR-3 & & $\begin{array}{l}\text { Multi-scale/multi-physics } \\
\text { simulation capability for the } \\
\text { following scope through } \\
\text { coupling: } \\
\text { (i) fuel rod, (ii) fuel assembly, } \\
\text { (iii) reactor, (iv) primary } \\
\text { RCS, (v) secondary coolant } \\
\text { system and BOP, (vi) I\&C, } \\
\text { (vii) containment, (viii) site } \\
\text { radiological consequences, } \\
\text { (ix) offsite radiological } \\
\text { consequences, (x) } \\
\text { fluid/structure interaction for } \\
\text { dynamic loads }\end{array}$ & $9 / 30 / 2015$ & $\begin{array}{l}\text { Coupling test with other } \\
\text { MOOSE-based } \\
\text { applications }\end{array}$ & $\begin{array}{l}\text { RELAP-7 can be } \\
\text { coupled with MOOSE } \\
\text { framework application } \\
\text { to simulate multi-scale / } \\
\text { multi-physics problems }\end{array}$ \\
\hline SR-4 & & $\begin{array}{l}\text { User-friendly steady-state } \\
\text { initialization and restart } \\
\text { capabilities }\end{array}$ & $9 / 30 / 2015$ & - & $\begin{array}{l}\text { Both steady-state and } \\
\text { transient cases can be } \\
\text { simulated by restart } \\
\text { option }\end{array}$ \\
\hline SR-5 & & $\begin{array}{l}\text { Clear and easy diagnostics to } \\
\text { assist with debugging and } \\
\text { workaround }\end{array}$ & $9 / 30 / 2015$ & - & $\begin{array}{l}\text { Code will show } \\
\text { highlighted error signal. } \\
\text { For example, if wrong } \\
\text { model type was give } \\
\text { then shows in red: } \\
* * * \text { ERROR*** } \\
\text { Unknown model type }\end{array}$ \\
\hline SR-6 & & $\begin{array}{l}\text { Comprehensive GUI for } \\
\text { pre/post-processing and on- } \\
\text { line monitoring }\end{array}$ & $9 / 30 / 2015$ & - & in progress \\
\hline SR-7 & & $\begin{array}{l}\text { Coupling capability with } \\
\text { other MOOSE-based codes } \\
\text { (e.g., RAVEN, BISON) and } \\
\text { CFD codes }\end{array}$ & $9 / 30 / 2015$ & $\begin{array}{l}\text { Verification test for } \\
\text { coupling with other } \\
\text { MOOSE-based } \\
\text { applications }\end{array}$ & $\begin{array}{l}\text { Can be coupled with } \\
\text { MOOSE-based BISON } \\
\text { code for 3D neutron } \\
\text { transport model. }\end{array}$ \\
\hline SR-7 & \multirow{2}{*}{$\begin{array}{l}\text { Code and } \\
\text { Modeling } \\
\text { Accuracy with } \\
\text { Reliability }\end{array}$} & $\begin{array}{l}\text { Capable of achieving CFD- } \\
\text { like resolution (3D) in } \\
\text { selected parts } \\
\text { (i.e., easily adjust the grid } \\
\text { resolution as needed) }\end{array}$ & $9 / 30 / 2015$ & Mesh management test & $\begin{array}{l}\text { RELAP-7 does not have } \\
\text { 3D mesh generation } \\
\text { model. }\end{array}$ \\
\hline SR-8 & & $\begin{array}{l}\text { Coordinate system to } \\
\text { represent the actual design of } \\
\text { a component with high } \\
\text { fidelity }\end{array}$ & 9/30/2015 & - & $\begin{array}{l}\text { Provides } \mathrm{x}, \mathrm{y}, \mathrm{z} \\
\text { coordination system for } \\
\text { components, functions, } \\
\text { etc }\end{array}$ \\
\hline
\end{tabular}


RELAP-7 Software Verification and Validation Plan: Requirements Traceability Matrix (RTM) Update and Code Verification Strategy

\begin{tabular}{|c|c|c|c|c|c|}
\hline SR-9 & & $\begin{array}{l}\text { Providing standard modules } \\
\text { with limited options for } \\
\text { various components or } \\
\text { systems to lessen the user } \\
\text { effect }\end{array}$ & $9 / 30 / 2015$ & - & $\begin{array}{l}\text { RELAP-7 supports } \\
\text { standard component } \\
\text { models }\end{array}$ \\
\hline SR-10 & & $\begin{array}{l}\text { Providing standard or } \\
\text { recommended options to } \\
\text { lessen the user effect on the } \\
\text { result }\end{array}$ & $9 / 30 / 2015$ & - & \\
\hline SR-11 & \multirow{4}{*}{$\begin{array}{l}\text { Physical } \\
\text { Phenomena }\end{array}$} & $\begin{array}{l}\text { Capability of addressing } \\
\text { legacy issues associated with } \\
\text { two-phase flow (e.g., (i) } \\
\text { phase separation, (ii) flow- } \\
\text { regime transition, (iii) level } \\
\text { tracking, (iv) water-packing, } \\
\text { (v) flooding, (vi) } \\
\text { entrainment/de-entrainment, } \\
\text { etc.) }\end{array}$ & $9 / 30 / 2015$ & - & $\begin{array}{l}\text { Both HEM and } 7 \\
\text { equation two-phase } \\
\text { model can be simulated }\end{array}$ \\
\hline SR-12 & & $\begin{array}{l}\text { Modeling capability of a } \\
\text { droplet field for BWR core } \\
\text { spray, containment spray } \\
\text { (PWR/BWR), and core } \\
\text { uncovery events }\end{array}$ & $9 / 30 / 2015$ & - & Not tested \\
\hline SR-13 & & $\begin{array}{l}\text { Modeling capability of } \\
\text { sources and transport of } \\
\text { particles in vapor, gas, droplet } \\
\text { and liquid }\end{array}$ & $9 / 30 / 2015$ & $\begin{array}{l}\text { Model V\&V in RELAP } 7 \\
\text { framework and/or code-to- } \\
\text { code comparison }\end{array}$ & Not tested \\
\hline SR-14 & & $\begin{array}{l}\text { Modeling capability of non- } \\
\text { condensable gas transport and } \\
\text { its heat transfer effect }\end{array}$ & $9 / 30 / 2015$ & $\begin{array}{l}\text { Model V\&V in RELAP } 7 \\
\text { framework and/or code-to- } \\
\text { code comparison }\end{array}$ & $\begin{array}{l}\text { The compressible valve } \\
\text { component can handle } \\
\text { non-condensible gas } \\
\text { model }\end{array}$ \\
\hline SR-15 & \multirow{4}{*}{$\begin{array}{c}\text { Software Quality } \\
\text { Assurance }\end{array}$} & $\begin{array}{l}\text { Writing the source code under } \\
\text { a consistent programming } \\
\text { standard for simplified } \\
\text { maintenance and revision }\end{array}$ & $9 / 30 / 2015$ & - & \\
\hline SR-16 & & $\begin{array}{l}\text { Providing detailed } \\
\text { documentation of theory, } \\
\text { programming, user manual, } \\
\text { validation basis and user } \\
\text { guidelines }\end{array}$ & $9 / 30 / 2015$ & - & $\begin{array}{l}\text { RELAP- } 7 \text { provides } \\
\text { revised theory manual. } \\
\text { Other documents are in } \\
\text { progress }\end{array}$ \\
\hline SR-17 & & $\begin{array}{l}\text { Check consistency of code } \\
\text { results depending on } \\
\text { computer hardware and } \\
\text { software environment (e.g., } \\
\text { compiler, libraries, etc.) }\end{array}$ & 9/30/2017 & - & \\
\hline SR-18 & & $\begin{array}{l}\text { Regression test and code } \\
\text { coverage test after any } \\
\text { updates in the source code }\end{array}$ & $9 / 30 / 2017$ & - & \\
\hline
\end{tabular}




\section{APPENDIX C. RELAP-7 CODE V\&V RTM (AS OF 2017)}

(A: Available, N/A: Not applicable or not available, P/A: Partially available, ver: verification, val: validation, sol: solution)

\begin{tabular}{|c|c|c|c|c|c|c|c|c|c|}
\hline Req \# & \multicolumn{2}{|c|}{ Test Type } & $\begin{array}{l}\text { Requirement Specification } \\
\text { (Target application, test }\end{array}$ & $\begin{array}{l}\text { Modification Date } \\
(\mathrm{mm} / \mathrm{dd} / \mathbf{y y y y})\end{array}$ & $\begin{array}{l}\text { NPP Design } \\
\text { Targeted }\end{array}$ & $\begin{array}{c}\text { Scale of } \\
\text { Experiment }\end{array}$ & Reference & $\begin{array}{c}\text { Data } \\
\text { Availability }\end{array}$ & $\begin{array}{l}\text { RELAP-7 } \\
\text { Test }\end{array}$ \\
\hline VR-1 & \multirow{7}{*}{$\begin{array}{l}\text { Code } \\
\text { Ver }\end{array}$} & ver & $\begin{array}{l}\text { Single-phase analytical test } \\
\text { without flow (uniform pressure, } \\
\text { zero flow velocity, variable } \\
\text { cross-sectional area) }\end{array}$ & $9 / 30 / 2016$ & - & - & $\begin{array}{l}\text { Suggested by RELAP-7 } \\
\text { development team }\end{array}$ & N/A & Tested \\
\hline VR-2 & & ver & $\begin{array}{l}\text { Two-phase analytical test } \\
\text { without flow (uniform pressure, } \\
\text { zero flow velocity, spatially } \\
\text { varying volume fraction) }\end{array}$ & $9 / 30 / 2016$ & - & - & $\begin{array}{l}\text { Suggested by RELAP-7 } \\
\text { development team }\end{array}$ & N/A & Tested \\
\hline VR-3 & & ver & $\begin{array}{l}\text { Two-phase analytical test for } \\
\text { volume fraction advection with } \\
\text { uniform pressure and velocity } \\
\text { field }\end{array}$ & $9 / 30 / 2016$ & - & - & $\begin{array}{l}\text { Suggested by RELAP-7 } \\
\text { development team }\end{array}$ & N/A & Tested \\
\hline VR-4 & & ver & $\begin{array}{l}\text { Grid convergence study for } \\
\text { single-/two-phase fluid flow } \\
\text { problems (order-of-accuracy } \\
\text { verification) }\end{array}$ & $9 / 30 / 2015$ & - & - & $\begin{array}{l}\text { - INL/EXT-14-33201 } \\
\text { - RELAP-7 verification coverage } \\
\text { suite (flow model) }\end{array}$ & N/A & In progress \\
\hline VR-5 & & ver & $\begin{array}{l}\text { Grid convergence study for heat } \\
\text { conduction problems } \\
\text { (order-of-accuracy verification) }\end{array}$ & $9 / 30 / 2015$ & - & - & $\begin{array}{l}\text { - INL/EXT-14-33201 } \\
\text { - RELAP-7 verification coverage } \\
\text { suite (heat conduction model) }\end{array}$ & N/A & Testable \\
\hline VR-6 & & ver & $\begin{array}{l}\text { Grid convergence study with } \\
\text { available stabilization schemes } \\
\text { (e.g., SUPG, Lapidus, Entropy } \\
\text { based viscosity scheme) }\end{array}$ & $9 / 30 / 2015$ & - & - & $\begin{array}{l}\text { - INL/EXT-14-33201 } \\
\text { - RELAP-7 verification coverage } \\
\text { suite (flow model) }\end{array}$ & N/A & Testable \\
\hline VR-7 & & ver & $\begin{array}{l}\text { Time step convergence study } \\
\text { with available options (order-of- } \\
\text { accuracy verification) } \\
\text { (e.g., Backward Euler, Crank- } \\
\text { Nicolson, BDF2) }\end{array}$ & $9 / 30 / 2015$ & - & - & $\begin{array}{l}\text { - INL/EXT-14-33201 } \\
\text { - RELAP-7 verification coverage } \\
\text { suite (flow model) }\end{array}$ & N/A & Testable \\
\hline
\end{tabular}


RELAP-7 Software Verification and Validation Plan: Requirements Traceability Matrix (RTM) Update and Code Verification Strategy

\begin{tabular}{|c|c|c|c|c|c|c|c|c|}
\hline VR-8 & ver & $\begin{array}{l}\text { Symmetry solution tests with } \\
\text { various boundary conditions } \\
\text { (e.g., fully developed channel } \\
\text { flow problem) }\end{array}$ & $9 / 30 / 2016$ & - & - & & N/A & Testable \\
\hline VR-9 & ver & $\begin{array}{l}\text { Solution independence tests to } \\
\text { coordinate transformation } \\
\text { (e.g., rotation, translation of } \\
\text { physical domain) }\end{array}$ & $9 / 30 / 2016$ & & & & N/A & $\begin{array}{l}\text { Partly } \\
\text { Tested }\end{array}$ \\
\hline VR-10 & ver & $\begin{array}{l}\text { Conservation tests in 0-D \& 1-D } \\
\text { components } \\
\text { (e.g., Branches/Junctions, LWR } \\
\text { components like steam generator } \\
\text { or pressurizer, pipe) }\end{array}$ & $9 / 30 / 2017$ & - & - & $\begin{array}{l}\text { - INL/EXT-14-33201 } \\
\text { - No et al. (2012) (SPACE code) }\end{array}$ & N/A & Testable \\
\hline VR-11 & ver & $\begin{array}{l}\text { Conservation tests in system } \\
\text { level of loop configuration }\end{array}$ & $9 / 30 / 2015$ & - & - & $\begin{array}{l}\text { - INL/EXT-14-33201 } \\
\text { - Specific problems should be } \\
\text { determined. }\end{array}$ & N/A & Testable \\
\hline VR-12 & ver & $\begin{array}{l}\text { Propagation of a passive scalar } \\
\text { property (related to the } \\
\text { capability of particle transport } \\
\text { simulation) }\end{array}$ & $9 / 30 / 2016$ & & & & N/A & Not ready \\
\hline VR-13 & ver & $\begin{array}{l}\text { Gravitational head effect \& } \\
\text { Countercurrent flow } \\
\text { development }\end{array}$ & $9 / 30 / 2016$ & - & - & $\begin{array}{l}\text { - Water faucet problem } \\
\text { (RELAP5-3D) } \\
\text { - Water over steam problem } \\
\text { (RELAP5-3D) }\end{array}$ & N/A & Testable \\
\hline VR-14 & ver & Heat conduction (1D/Multi-D) & $9 / 30 / 2016$ & - & - & $\begin{array}{l}\text { Heat conduction enclosure } \\
\text { (RELAP5-3D, TRACE) }\end{array}$ & N/A & Testable \\
\hline VR-15 & ver & $\begin{array}{l}\text { Decay heat model test with } \\
\text { various decay options }\end{array}$ & $9 / 30 / 2015$ & - & - & $\begin{array}{l}\text { Decay heat model test (RELAP5- } \\
\text { 3D) }\end{array}$ & N/A & Not ready \\
\hline VR-16 & ver & Reactor kinetics model & $9 / 30 / 2015$ & - & - & $\begin{array}{l}\text { Reactor kinetics model test } \\
\text { (RELAP5-3D) }\end{array}$ & N/A & $\begin{array}{l}\text { Need to } \\
\text { check }\end{array}$ \\
\hline VR-17 & ver & $\begin{array}{l}\text { Metal-water reaction model } \\
\text { (e.g., Zr-cladding oxidation) }\end{array}$ & $9 / 30 / 2015$ & - & - & $\begin{array}{l}\text { Metal-water reaction model test } \\
\text { (RELAP5-3D) }\end{array}$ & N/A & Not ready \\
\hline VR-18 & ver & $\begin{array}{l}\text { Wall-to-fluid friction (single } \\
\text { phase) }\end{array}$ & $9 / 30 / 2015$ & - & FT & $\begin{array}{l}\text { - Darcy pressure drop equation } \\
\text { (horizontal pipe) (TRACE) } \\
\text { - Wang's falling film data } \\
\text { (TRACE) }\end{array}$ & N/A, A & Testable \\
\hline VR-19 & ver & Single-phase shock problem & $9 / 30 / 2016$ & - & FT & $\begin{array}{l}\text { - D. L. Youngs, "Shock Tube", } \\
\text { Multiphase Science and } \\
\text { Technology, Vol. } 6 \text { p653-662 } \\
\text { - S. Mimouni and G. Serre, "List } \\
\text { of benchmarks for simulation } \\
\text { tools of steam-water two-phase } \\
\text { flows", } 2000\end{array}$ & N/A & Testable \\
\hline
\end{tabular}


RELAP-7 Software Verification and Validation Plan: Requirements Traceability Matrix (RTM) Update and Code Verification Strategy

\begin{tabular}{|c|c|c|c|c|c|c|c|c|c|}
\hline VR-20 & \multirow[t]{2}{*}{ Sol Ver } & ver & $\begin{array}{l}\text { Numerical error estimation for a } \\
\text { given complex problem } \\
\text { depending on spatial and } \\
\text { temporal discretization }\end{array}$ & $9 / 30 / 2016$ & & & $\begin{array}{l}\text { - Specific problems should be } \\
\text { determined. }\end{array}$ & N/A & Testable \\
\hline VR-21 & & ver & $\begin{array}{l}\text { Numerical error estimation for } \\
\text { all non-linear solver settings } \\
\text { (e.g., JFNK) }\end{array}$ & 9/30/2016 & & & $\begin{array}{l}\text { - Specific problems should be } \\
\text { determined. }\end{array}$ & N/A & Testable \\
\hline VR-22 & \multirow{7}{*}{$\begin{array}{l}\text { Model } \\
\text { Val }\end{array}$} & val & $\begin{array}{l}\text { Wall-to-fluid friction (two } \\
\text { phase) }\end{array}$ & 9/30/2015 & - & FT & $\begin{array}{l}\text { - Ferrell-Bylund uniform test } \\
\text { section data (TRACE) }\end{array}$ & A & Testable \\
\hline VR-23 & & val & $\begin{array}{l}\text { Two-phase shock problem } \\
\text { (boiling front propagation) }\end{array}$ & $9 / 30 / 2016$ & - & FT & $\begin{array}{l}\text { J.R. Simoes-Moreira and J.E. } \\
\text { Shepherd (J. Fluid Mech., } \\
\text { "Evaporation waves in } \\
\text { superheated dodecane," 1999) }\end{array}$ & A & Testable \\
\hline VR-24 & & val & $\begin{array}{l}\text { Single-phase pressure drop at } \\
\text { geometric discontinuities }\end{array}$ & $9 / 30 / 2015$ & - & FT & $\begin{array}{l}\text { - Ferrell-McGee pressure drop } \\
\text { test (TRACE) } \\
\text { (abrupt area change test section } \\
\text { data) }\end{array}$ & A & Not ready \\
\hline VR-25 & & val & $\begin{array}{l}\text { Two-phase pressure drop at } \\
\text { geometric discontinuities }\end{array}$ & $9 / 30 / 2015$ & - & FT & $\begin{array}{l}\text { - Ferrell-McGee pressure drop } \\
\text { test (TRACE) } \\
\text { (abrupt area change test section } \\
\text { data) }\end{array}$ & A & Not ready \\
\hline VR-26 & & val & Water hammer (single-phase) & $9 / 30 / 2015$ & - & FT & $\begin{array}{l}\text { - EPRI NP-6766, Vol.4, Part1 } \\
\text { (1992) } \\
\text { - NUREG/IA-0206 (2007) } \\
\text { - Simpsons water hammer test } \\
\text { (A.R. Simption's PhD Thesis, } \\
\text { 1986; Serre and Bestion, "Two- } \\
\text { Phase Water Hammer Simulation } \\
\text { with CATHARE Code") }\end{array}$ & A & Testable \\
\hline VR-27 & & val & Water hammer (two-phase) & $9 / 30 / 2015$ & & FT & $\begin{array}{l}\text { - Tiselj and Cerne (Nucl. Sci. } \\
\text { Eng., Vol. 134, 2000) } \\
\text { - Cerne et al. (Trans ANS, Vol. } \\
\text { 75, 1996) } \\
\text { - Serre and Bestion ("Two-Phase } \\
\text { Water Hammer Simulation with } \\
\text { CATHARE Code") }\end{array}$ & A & Testable \\
\hline VR-28 & & val & Flow split (T-junction) & 9/30/2016 & - & FT & $\begin{array}{l}\text { - No et al. (2012) (SPACE code): } \\
\text { Branch reentrant tee/cross-flow } \\
\text { tee/cross tank problems (Table } \\
\text { II) }\end{array}$ & N/A & Not ready \\
\hline
\end{tabular}


RELAP-7 Software Verification and Validation Plan: Requirements Traceability Matrix (RTM) Update and Code Verification Strategy

\begin{tabular}{|c|c|c|c|c|c|c|c|c|}
\hline VR-29 & ver, val & $\begin{array}{l}\text { Convective heat transfer (single- } \\
\text { phase) }\end{array}$ & 9/30/2015 & - & FT & $\begin{array}{l}\text { - Turbulent forced convection: } \\
\text { Dittus-Boelter, Petukhov, } \\
\text { Inayatov (for vertical bundles), } \\
\text { etc. } \\
\text { - Laminar forced convection: } \\
\text { Nu=7.63 (ORNL/ANS/INT- } \\
\text { 5/V19, RELAP5-3D), Elenbaas, } \\
\text { etc. } \\
\text { - Natural convection: McAdams, } \\
\text { Churchill-chu, etc. } \\
\text { - Forced laminar or natural } \\
\text { convection for vertical bundles } \\
\text { (non-existent) }\end{array}$ & P/A & Testable \\
\hline VR-30 & val & $\begin{array}{l}\text { Interphase friction in vertical } \\
\text { flow }\end{array}$ & 9/30/2015 & - & FT & - CISE Adiabatic Tube (TRACE) & A & Testable \\
\hline VR-31 & val & $\begin{array}{l}\text { Phase separation/distribution in } \\
\text { vertical flow }\end{array}$ & 9/30/2015 & - & FT & $\begin{array}{l}\text { - Wilson Bubble Rise test data } \\
\text { (TRACE) } \\
\text { - GE Vessel Blowdown Level } \\
\text { Swell data (1 ft small diameter } \\
\text { vessel; } 4 \mathrm{ft} \text { large diameter vessel) } \\
\text { (TRACE, RELAP5-3D) } \\
\text { - Sedimentation test problem } \\
\text { (RELAP-7 HPC repository) }\end{array}$ & A & Tested \\
\hline VR-32 & val & $\begin{array}{l}\text { Phase separation/distribution in } \\
\text { horizontal flow }\end{array}$ & 9/30/2015 & - & FT & $\begin{array}{l}\text { - Edward's Pipe Blowdown data } \\
\text { (RELAP5,RETRAN-3D): ISP-01 } \\
\text { - TRTF Horizontal Flow } \\
\text { (TRACE) }\end{array}$ & A & Testable \\
\hline VR-33 & val & $\begin{array}{l}\text { Phase separation/distribution at } \\
\text { branch }\end{array}$ & 9/30/2016 & - & FT & - & N/A & $\begin{array}{l}\text { Need to } \\
\text { check }\end{array}$ \\
\hline VR-34 & val & $\begin{array}{l}\text { Level tracking during flow } \\
\text { oscillation } \\
\text { (single-phase) }\end{array}$ & 9/30/2015 & - & FT & $\begin{array}{l}\text { - Fill-drain assessment problem } \\
\text { - Manometer problem (RELAP5- } \\
\text { 3D, TRACE, SPACE) } \\
\text { - Gravity wave tests (1D, 3D) } \\
\text { (RELAP5-3D) }\end{array}$ & A & $\begin{array}{l}\text { Need to } \\
\text { check }\end{array}$ \\
\hline VR-35 & val & Two-phase mixture level swell & 9/30/2015 & - & FT & $\begin{array}{l}\text { - Single tube flooding test } \\
\text { (TRACE) } \\
\text { - Bubbling steam through liquid } \\
\text { (RELAP5-3D) }\end{array}$ & - & Testable \\
\hline
\end{tabular}


RELAP-7 Software Verification and Validation Plan: Requirements Traceability Matrix (RTM) Update and Code Verification Strategy

\begin{tabular}{|c|c|c|c|c|c|c|c|c|}
\hline VR-36 & val & $\begin{array}{l}\text { Entrainment/de-entrainment in } \\
\text { vertical flow }\end{array}$ & $9 / 30 / 2015$ & - & FT & $\begin{array}{l}\text { - GE Vessel Blowdown Level } \\
\text { Swell data (1 ft small diameter } \\
\text { vessel; } 4 \mathrm{ft} \text { large diameter vessel) } \\
\text { (TRACE, RELAP5-3D) } \\
\text { - Cousin's vertical annular flow } \\
\text { (SPACE) }\end{array}$ & A & Testable \\
\hline VR-37 & val & $\begin{array}{l}\text { Entrainment/de-entrainment in } \\
\text { horizontal flow }\end{array}$ & $9 / 30 / 2017$ & & & $\begin{array}{l}\text { - Mantilla horizontal annular } \\
\text { flow (SPACE) }\end{array}$ & A & \\
\hline VR-38 & val & Flashing in vertical flow & $9 / 30 / 2016$ & - & FT & $\begin{array}{l}\text { - GE Vessel Blowdown Level } \\
\text { Swell data ( } 1 \mathrm{ft} \text { small diameter } \\
\text { vessel; } 4 \mathrm{ft} \text { large diameter vessel) } \\
\text { (TRACE, RELAP5-3D) }\end{array}$ & A & Not ready \\
\hline VR-39 & val & Flashing in horizontal flow & $9 / 30 / 2016$ & - & FT & $\begin{array}{l}\text { - Edward's Pipe Blowdown data } \\
\text { (RELAP5,RETRAN-3D): ISP-01 } \\
\text { - TPTF Horizontal Flow } \\
\text { (TRACE) } \\
\text { - Saruel et al. (2008), "Modelling } \\
\text { phase transition in metastable } \\
\text { liquids: application to cavitating } \\
\text { and flashing flows," J. Fluid } \\
\text { Mech. }\end{array}$ & A & Not ready \\
\hline VR-40 & val & Counter-current flow & $9 / 30 / 2015$ & - & FT & $\begin{array}{l}\text { - Single tube flooding test } \\
\text { (TRACE) }\end{array}$ & $\mathrm{A}+$ & Not ready \\
\hline VR-41 & val & $\begin{array}{l}\text { Counter-current flow limitation } \\
\text { (CCFL) }\end{array}$ & $9 / 30 / 2015$ & - & FT & $\begin{array}{l}\text { - Single tube flooding test } \\
\text { (TRACE) } \\
\text { - Bankoff CCFL test (TRACE) } \\
\text { - Dukler-Smith Air-Water } \\
\text { Flooding test (RELAP5-3D) }\end{array}$ & A & Not ready \\
\hline VR-42 & val & Convective boiling heat transfer & $9 / 30 / 2015$ & - & FT & $\begin{array}{l}\text { - Christensen Subcooled Boiling } \\
\text { (RELAP5, RELAP5-3D) } \\
\text { - Bennett Heated Tube } \\
\text { (RELAP5, RELAP5-3D, } \\
\text { RETRAN-3D) }\end{array}$ & A & Testable \\
\hline VR-43 & val & Critical Heat Flux (CHF)/dryout & $9 / 30 / 2015$ & - & FT & $\begin{array}{l}\text { - Bennett Heated Tube } \\
\text { (RELAP5, RELAP5-3D, } \\
\text { RETRAN-3D) }\end{array}$ & A & Testable \\
\hline VR-44 & val & Re-wetting heat transfer & $9 / 30 / 2015$ & - & FT & $\begin{array}{l}\text { - ORNL THTF Transient } \\
\text { Blowdown test (TRACE) } \\
\text { - GOTA BWR Reflood test } \\
\text { (TRACE) }\end{array}$ & A & Testable \\
\hline VR-45 & val & $\begin{array}{l}\text { Film Boiling (FB)/superheating } \\
\text { heat transfer }\end{array}$ & $9 / 30 / 2015$ & - & FT & $\begin{array}{l}\text { - Bennett Heated Tube } \\
\text { (RELAP5, RELAP5-3D, } \\
\text { RETRAN-3D) }\end{array}$ & A & Testable \\
\hline
\end{tabular}


RELAP-7 Software Verification and Validation Plan: Requirements Traceability Matrix (RTM) Update and Code Verification Strategy

\begin{tabular}{|c|c|c|c|c|c|c|c|c|}
\hline VR-46 & val & $\begin{array}{l}\text { Superheating due to } \\
\text { compression }\end{array}$ & $9 / 30 / 2016$ & - & FT & $\begin{array}{l}\text { - MIT pressurizer (TRACE, } \\
\text { RELAP5, RELAP5-3D, } \\
\text { RETRAN-3D) }\end{array}$ & A & $\begin{array}{l}\text { Need to } \\
\text { check }\end{array}$ \\
\hline VR-47 & val & Radiation heat transfer & $9 / 30 / 2016$ & - & FT & $\begin{array}{l}\text { - GOTA BWR Radiation (Run } \\
\text { 27, TRACE) }\end{array}$ & A & $\begin{array}{c}\text { Partly } \\
\text { Testable }\end{array}$ \\
\hline VR-48 & val & Interphase heat transfer & $9 / 30 / 2016$ & - & FT & $\begin{array}{l}\text { - UCB-Kuhn Condensation } \\
\text { (TRACE) } \\
\text { - MIT pressurizer (TRACE, } \\
\text { RELAP5, RELAP5-3D, } \\
\text { RETRAN-3D) }\end{array}$ & A & Testable \\
\hline VR-49 & val & Condensation heat transfer & $9 / 30 / 2015$ & - & FT & $\begin{array}{l}\text { - Dehbi-MIT Condensation With } \\
\text { NCG (TRACE) } \\
\text { - University of Wisconsin } \\
\text { Condensation (TRACE) }\end{array}$ & A & Testable \\
\hline VR-50 & val & Critical flow and blowdown & $9 / 30 / 2015$ & - & FT & $\begin{array}{l}\text { - Marviken test data } \\
\text { (NUREG/IA-0007) (TRACE, } \\
\text { RELAP5, RELAP5-3D, } \\
\text { RETRAN-3D) } \\
\text { - Moby Dick nozzle tests } \\
\text { (RELAP5-3D, TRACE) } \\
\text { - Super Moby Dick } \\
\text { - Edwards-O'Brien blowdown } \\
\text { test (RELAP5-3D), ISP-01 }\end{array}$ & A & Testable \\
\hline VR-51 & val & Non-condensable gas effects & $9 / 30 / 2016$ & - & FT & $\begin{array}{l}\text { - UCB-Kuhn Condensation Tests } \\
\text { (TRACE) } \\
\text { - Dehbi-MIT Condensation Tests } \\
\text { (TRACE) } \\
\text { - University of Wisconsin } \\
\text { Condensation Tests (TRACE) }\end{array}$ & A & Not ready \\
\hline VR-52 & val & Single-phase natural circulation & 9/30/2015 & - & FT & NUREG/IA-0151 (1999) & A & Testable \\
\hline VR-53 & val & Boron mixing and transport & $9 / 30 / 2015$ & - & FT & & N/A & Not ready \\
\hline VR-54 & val & Offtake test & 9/30/2017 & - & FT & - Offtake test models & & \\
\hline
\end{tabular}




\section{- Code V\&V RTM for SET and CT (continued)}

\begin{tabular}{|c|c|c|c|c|c|c|c|c|}
\hline Req \# & $\begin{array}{l}\text { Test } \\
\text { Type }\end{array}$ & $\begin{array}{c}\text { Requirement Specification } \\
\text { (Target application, test } \\
\text { feature) }\end{array}$ & $\begin{array}{c}\text { Modification Date } \\
\text { (dd/mm/yyyy) }\end{array}$ & $\begin{array}{l}\text { NPP Design } \\
\text { Targeted }\end{array}$ & $\begin{array}{c}\text { Scale of } \\
\text { Experiment }\end{array}$ & $\begin{array}{c}\text { Reference } \\
\text { (Experiment, Test ID, } \\
\text { Reference) }\end{array}$ & $\begin{array}{c}\text { Data } \\
\text { Availability }\end{array}$ & $\begin{array}{c}\text { RELAP-7 } \\
\text { Test } \\
\text { Status }\end{array}$ \\
\hline VR-55 & val & $\begin{array}{c}\text { SBLOCA } \\
\text { (Boil-off, Void Distribution) }\end{array}$ & $09 / 31 / 2016$ & PWR & SET & $\begin{array}{l}\text { ORNL THTF SBLOCA test } \\
\text { series data: } \\
\text { - Tests 3.09.10I to 10N (core } \\
\text { uncovered) } \\
\text { - Tests 3.09.10AA to 10FF } \\
\text { (core covered)* } \\
\text { - NUREG/CR-2456, } \\
\text { NUREG/CR-2640 } \\
\text { - (TRACE, RELAP5, } \\
\text { RELAP5-3D, RETRAN-3D) }\end{array}$ & A & Not ready \\
\hline VR-56 & val & $\begin{array}{c}\text { Film Boiling Heat Transfer, } \\
\text { CHF }\end{array}$ & 09/31/2016 & PWR & SET & $\begin{array}{l}\text { ORNL THTF Film Boiling } \\
\text { Bundle Uncovery CHF data: } \\
\text { - Tests 3.07.9B, H, N, W } \\
\text { - NUREG/CR-2640 } \\
\text { - (TRACE, RELAP5, } \\
\text { RELAP5-3D) }\end{array}$ & A & Testable \\
\hline VR-57 & val & $\begin{array}{c}\text { Blowdown, Film Boiling Heat } \\
\text { Transfer }\end{array}$ & $09 / 31 / 2016$ & PWR & SET & $\begin{array}{l}\text { ORNL THTF Transient } \\
\text { Blowdown data: } \\
\text { - Tests 3.03.6AR, 3.06.6B, } \\
\text { 3.08.6C } \\
\text { - NUREG/CR-2640 } \\
\text { - (TRACE) }\end{array}$ & A & Testable \\
\hline VR-58 & val & $\begin{array}{c}\text { Blowdown } \\
\text { (Pressure/Void fraction } \\
\text { Variation) }\end{array}$ & 09/31/2016 & - & SET & $\begin{array}{l}\text { - GE Level Swell Test, } 1 \mathrm{ft} . \\
\text { diameter: Test } 1004-3 \\
\text { - GE Level Swell, } 4 \mathrm{ft} \text { diameter: } \\
\text { Tests 5801-15, 5702-16 } \\
\text { (RELAP5-3D, TRACE) }\end{array}$ & A & Testable \\
\hline
\end{tabular}


RELAP-7 Software Verification and Validation Plan: Requirements Traceability Matrix (RTM) Update and Code Verification Strategy

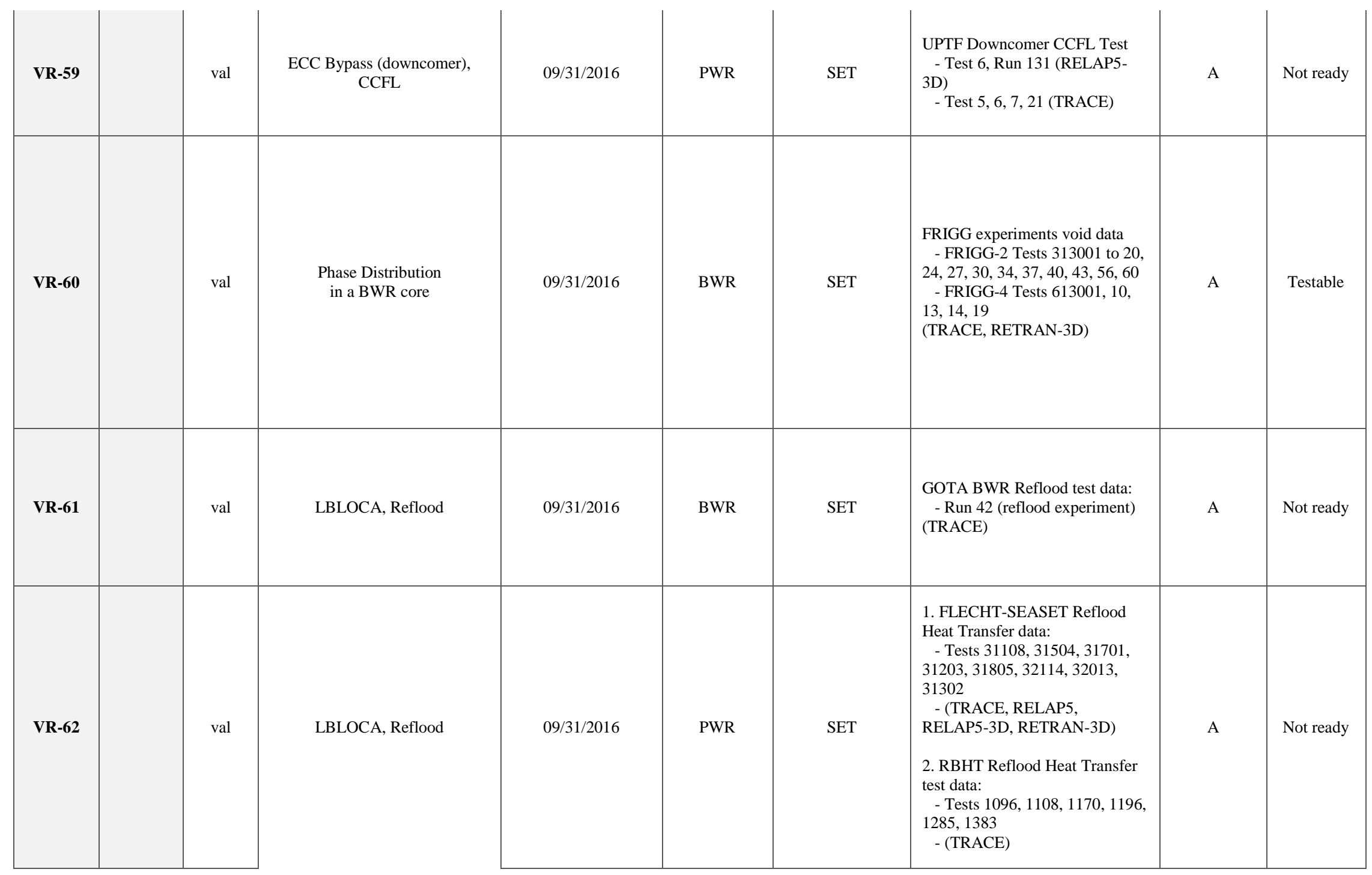


RELAP-7 Software Verification and Validation Plan: Requirements Traceability Matrix (RTM) Update and Code Verification Strategy

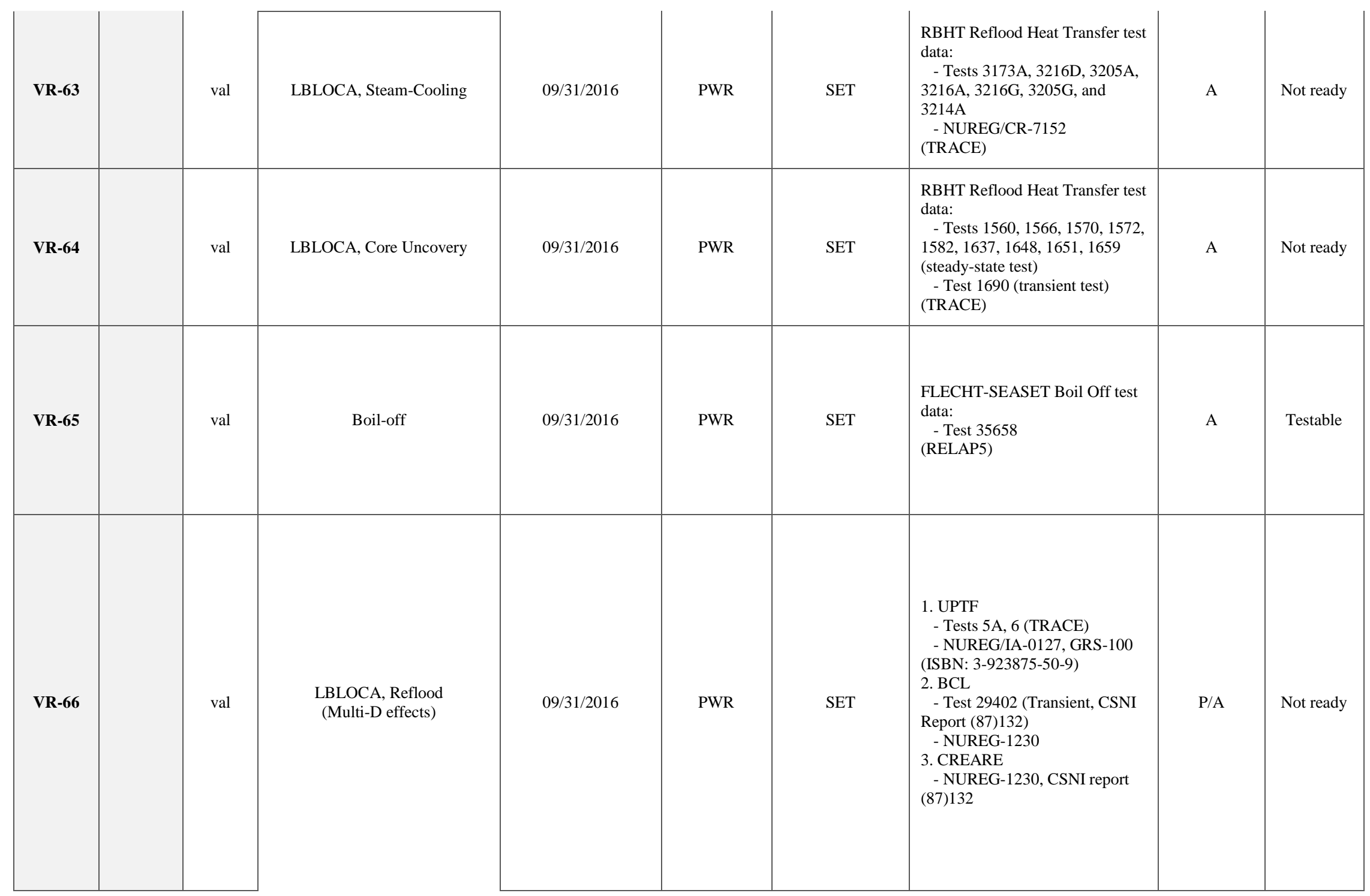


RELAP-7 Software Verification and Validation Plan: Requirements Traceability Matrix (RTM) Update and Code Verification Strategy

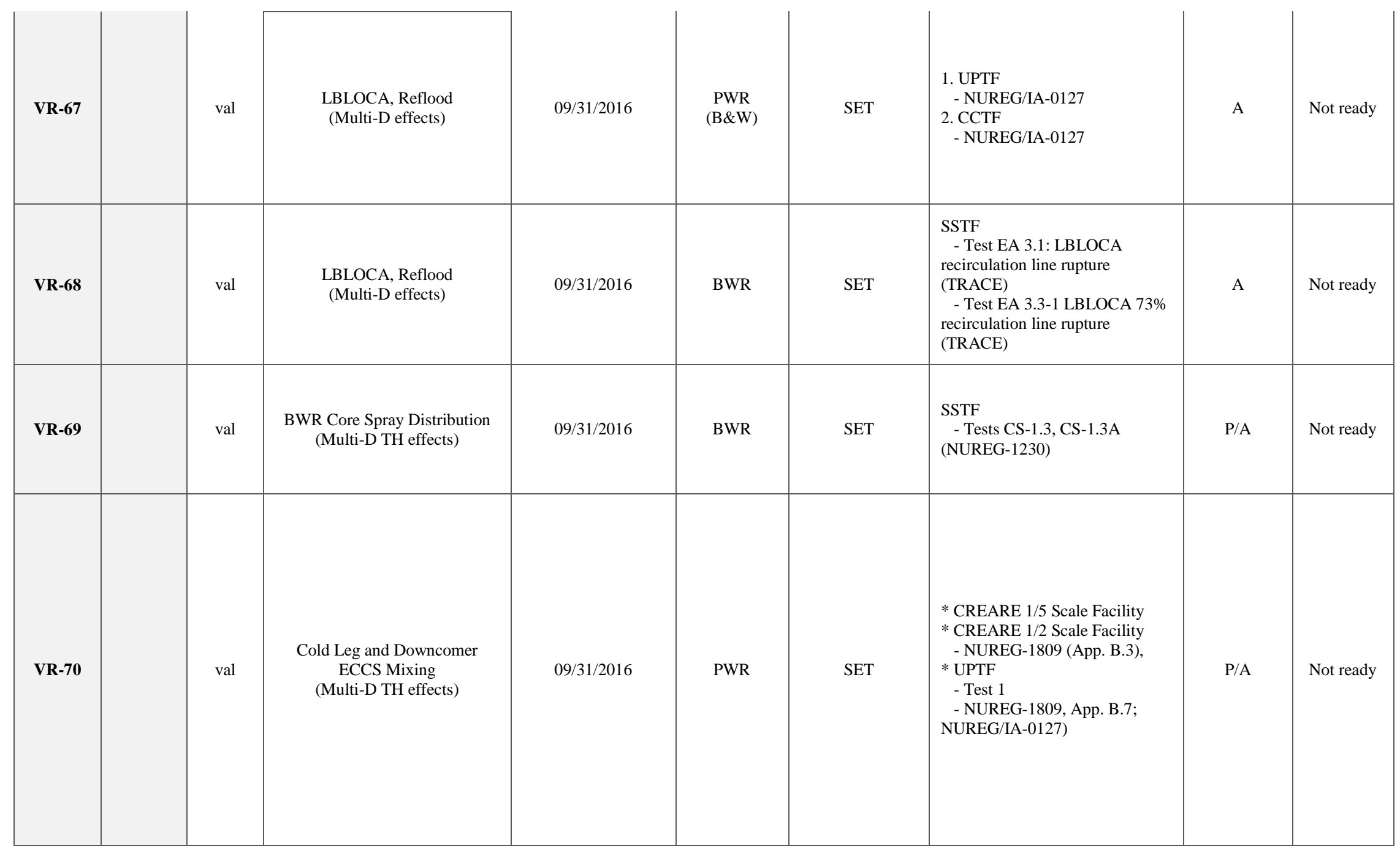


RELAP-7 Software Verification and Validation Plan: Requirements Traceability Matrix (RTM) Update and Code Verification Strategy

\begin{tabular}{|c|c|c|c|c|c|c|c|c|}
\hline VR-71 & val & $\begin{array}{l}\text { UPI ECCS during LOCA } \\
\text { (Multi-D effects) }\end{array}$ & $09 / 31 / 2016$ & PWR & SET & $\begin{array}{l}\text { 1. UPTF } \\
\text { - NUREG/IA-0127 } \\
\text { 2. CCTF } \\
\text { - NUREG/IA-0127, NUREG- } \\
\text { 1230 (Rev. 4) } \\
\text { 3. SCTF } \\
\text { - NUREG/IA-0127, NUREG- } \\
\text { 1230 (Rev. 4) }\end{array}$ & $\mathrm{P} / \mathrm{A}$ & Not ready \\
\hline VR-72 & val & Jet Pump & 09/31/2016 & BWR & $\mathrm{CT}$ & $\begin{array}{l}\text { 1. INEL 1/6 Scale Jet Pump Test } \\
\text { - RELAP5-3D } \\
\text { - H. S. Crapo, Idaho National } \\
\text { Engineering Report (EGG- } \\
\text { LOFT-6063), Nov. 1979 } \\
\text { 2. Small Scale Jet Pumps for the } \\
\text { FIST facility } \\
\text { - NUREG/CR-2576 } \\
\text { 3. Full Scale Jet Pumps } \\
\text { - For BWR4, } \\
\text { Boiling Water Reactor } \\
\text { Turbine Trip (TT) Benchmark, } \\
\text { Vol. I: Final Specifications, } \\
\text { NEA/NSC/2001-1. } \\
\text { - For BWR6, } \\
\text { Kudirka, A. A. and Glustz, D. } \\
\text { M., Fluid Machinery and Nuclear } \\
\text { Energy Groups Joint Convention, } \\
\text { Pumps for Nuclear Power Plant, } \\
\text { the Institution of Mechanical } \\
\text { Engineers, Bath, England, April } \\
\text { 22-25, 1974 }\end{array}$ & A & Not ready \\
\hline VR-73 & val & Recirculation pump & $09 / 31 / 2016$ & BWR & CT & $\begin{array}{l}\text { 1. Small Scale Recirculation } \\
\text { Pumps in FIST facility } \\
\text { - NUREG/CR-2576 } \\
\text { 2. Full Scale Recirculation } \\
\text { Pumps } \\
\text { - For BWR4, } \\
\quad \text { Boiling Water Reactor } \\
\text { Turbine Trip (TT) Benchmark, } \\
\text { Vol. I: Final Specifications, } \\
\text { NEA/NSC/2001-1. }\end{array}$ & A & Testable \\
\hline
\end{tabular}


RELAP-7 Software Verification and Validation Plan: Requirements Traceability Matrix (RTM) Update and Code Verification Strategy

\begin{tabular}{|c|c|c|c|c|c|c|c|c|}
\hline VR-74 & val & Separator & 09/31/2016 & BWR & CT & $\begin{array}{l}\text { - Boiling Water Reactor Turbine } \\
\text { Trip (TT) Benchmark, Vol. I: } \\
\text { Final Specifications, } \\
\text { NEA/NSC/2001-1. }\end{array}$ & A & Testable \\
\hline VR-75 & val & $\begin{array}{l}\text { Reactor coolant pump } \\
\text { steady-state, startup, and } \\
\text { coastdown }\end{array}$ & 09/31/2016 & PWR & CT & $\begin{array}{l}\text { - OPR-1000 test data, OPR-1000 } \\
\text { transient data (SPACE) }\end{array}$ & A & $\begin{array}{l}\text { Need to } \\
\text { check }\end{array}$ \\
\hline VR-76 & val & $\begin{array}{l}\text { Reactor coolant pump two- } \\
\text { phase operation }\end{array}$ & 09/31/2016 & PWR & CT & $\begin{array}{l}\text { 1. Full scale RCP two-phase } \\
\text { - TMI-2 accident } \\
\text { 2. Scaled RCP } \\
\text { - LOFT tests } \\
\text { - ROSA-IV tests } \\
\text { 3. Scaled RCP two-phase } \\
\text { - EPRI/CE 1/5 scale (EPRI NP- } \\
\text { 1556) } \\
\text { - LOFT Tests L3-5 and L3-6 }\end{array}$ & A & Not ready \\
\hline VR-77 & val & Pressurizer & 09/31/2016 & PWR & CT & $\begin{array}{l}\text { 1. Full scale pressurizer } \\
-P \text { PR startup test and event } \\
\text { data } \\
\text { - Doel } 4 \text { startup test } \\
\text { (NUREG/IA-0020) } \\
\text { 2. Scaled pressurizer } \\
\text { - MIT pressurizer (TRACE, } \\
\text { RELAP5, RELAP5-3D, } \\
\text { RETRAN-3D) } \\
\text { - NEPTUNUS test (RELAP5- } \\
\text { 3D, NUREG/IA-0040) } \\
\text { - ISP-38 }\end{array}$ & A & Testable \\
\hline VR-78 & val & Accumulator & 09/31/2016 & PWR & CT & $\begin{array}{l}\text { 1. Full scale accumulator } \\
\text { - } P \text { WR accumulator injection } \\
\text { test data } \\
\text { 2. Scaled accumulator } \\
\text { - LOFT accumulator blowdown } \\
\text { test (L3-1) } \\
\text { (RELAP5, RELAP5-3D, } \\
\text { RETRAN-3D) }\end{array}$ & A & Testable \\
\hline
\end{tabular}


RELAP-7 Software Verification and Validation Plan: Requirements Traceability Matrix (RTM) Update and Code Verification Strategy

\begin{tabular}{|c|c|c|c|c|c|c|c|c|}
\hline VR-79 & val & U-tube steam generator & 09/31/2016 & PWR & CT & $\begin{array}{l}\text { 1. Full scale U-tube steam } \\
\text { generator } \\
\text { - NUREG/IA-0113 } \\
\text { - NUREG/IA-0106 } \\
\text { 2. Scaled U-tube steam generator } \\
\text { - Westinghouse Model Boiler-2 } \\
\text { (NUREG/IA-224) } \\
\text { - Kalra, S., Yao, L. S., and } \\
\text { Davis, W. E. R. "Flow Behavior } \\
\text { in a Static Vane Centrifugal } \\
\text { Separator-Simulation } \\
\text { Experiments and Analysis," } \\
\text { Second International Topical } \\
\text { Meeting on Nuclear Reactor } \\
\text { Thermal Hydraulics, January, } \\
\text { 1983. } \\
\text { (RELAP5-3D, TRACE) }\end{array}$ & A & Not ready \\
\hline VR-80 & val & $\begin{array}{l}\text { Once-through steam generator } \\
\text { (OTSG) }\end{array}$ & 09/31/2016 & $\begin{array}{l}\text { PWR } \\
(\mathrm{B} \& W)\end{array}$ & CT & $\begin{array}{l}\text { 1. Scaled OTSG } \\
\text { - NUREG/CR-5395, } \\
\text { NUREG/CR-4567 } \\
\text { - "Simulation of a 30-Tube } \\
\text { Once-Through Steam Generator } \\
\text { with RELAP5/MOD3 and } \\
\text { RELAP5/MOD2 Computer } \\
\text { Codes," Hassan, Y. A., Salim, P., } \\
\text { ANS Winter Meeting, } \\
\text { November, } 1990 \text { (OSTI ID: } \\
\text { 6780203) }\end{array}$ & A & Not ready \\
\hline VR-81 & val & Hot leg (two-phase) & 09/31/2016 & $\begin{array}{l}\text { PWR } \\
(\mathrm{B} \& W)\end{array}$ & CT & $\begin{array}{l}\text { 1. Scaled hot leg } \\
\text { - NUREG/CR-5395 } \\
\text { - NUREG/CR-4567 } \\
\text { 2. Full scale } \\
\text { - No data exists }\end{array}$ & A & Testable \\
\hline VR-82 & val & $\begin{array}{c}\text { Reactor vessel internals vent } \\
\text { valves (RVVV) }\end{array}$ & $09 / 31 / 2016$ & $\begin{array}{l}\text { PWR } \\
(\mathrm{B} \& W)\end{array}$ & CT & $\begin{array}{l}\text { 1. Full Scale RVVV } \\
\text { - NUREG-1230, Section } \\
\text { 6.4.3.11 } \\
\text { 2. Scaled RVVV } \\
\text { - UPTF test data (NUREG/IA- } \\
\text { 0127) } \\
\text {-"Summary of Downcomer } \\
\text { Injection Phenomena for UPTF } \\
\text { and TRAC Post-Test Analysis," } \\
\text { LACP-92-188, May 1992 } \\
\text { - CCTF test data (NUREG/IA- } \\
\text { 0127): Test C2-AS2, Test C2-10 }\end{array}$ & A & $\begin{array}{l}\text { Need to } \\
\text { check }\end{array}$ \\
\hline
\end{tabular}


RELAP-7 Software Verification and Validation Plan: Requirements Traceability Matrix (RTM) Update and Code Verification Strategy

- Code V\&V RTM for IET and PT (continued)

\begin{tabular}{|c|c|c|c|c|c|c|c|c|}
\hline Req \# & $\begin{array}{l}\text { Test } \\
\text { Type }\end{array}$ & $\begin{array}{c}\text { Requirement Specification } \\
\text { (Target application, test } \\
\text { feature) }\end{array}$ & $\begin{array}{l}\text { Modification Date } \\
\text { (dd/mm/yyyy) }\end{array}$ & $\begin{array}{l}\text { NPP Design } \\
\text { Targeted }\end{array}$ & $\begin{array}{c}\text { Scale of } \\
\text { Experiment }\end{array}$ & $\begin{array}{c}\text { Reference } \\
\text { (Experiment, Test ID, } \\
\text { Reference) }\end{array}$ & $\begin{array}{c}\text { Data } \\
\text { Availabili } \\
\text { ty }\end{array}$ & $\begin{array}{c}\text { RELAP-7 } \\
\text { Test } \\
\text { Status }\end{array}$ \\
\hline VR-83 & val & SBLOCA & $09 / 31 / 2016$ & BWR & IET & $\begin{array}{l}\text { FIST (Full Integral System Test) } \\
\text { facility } \\
\text { - SBLOCA test 6SB2C } \\
\text { - NUREG/CR-2576 } \\
\text { - (TRACE) }\end{array}$ & A & Not ready \\
\hline VR-84 & val & LBLOCA & $09 / 31 / 2016$ & BWR & IET & $\begin{array}{l}\text { 1. FIST facility } \\
\text { - LBLOCA test 6DBA1B } \\
\text { - NUREG/CR-2576, } \\
\text { NUREG/CR-3711 } \\
\text { 2. FIST facility } \\
\text { - LBLOCA test 4DBA1 } \\
\text { - NUREG/CR-2576, } \\
\text { NUREG/CR-4128 } \\
\text { 3. TLTA (Two Loop Test } \\
\text { Apparatus) facility } \\
\text { - LBLOCA Conservative test } \\
\text { 6423 } \\
\text { - NUREG/CR-2229, GEAP- } \\
\text { 23592 (TLTA facility description), } \\
\text { GEAP-NUREG-23977 } \\
\text { 4. TLTA (Two Loop Test } \\
\text { Apparatus) facility } \\
\text { - LBLOCA test 6425 } \\
\text { - NUREG/CR-2229, GEAP- } \\
\text { 23592 (TLTA facility description), } \\
\text { GEAP-NUREG-23977 } \\
\text { - (TRACE) } \\
\text { 5. TLTA (Two Loop Test } \\
\text { Apparatus) facility } \\
\text { - LBLOCA tests 6425, 6424 } \\
\text { - NUREG/CR-2229, GEAP- } \\
\text { NUREG-23977 } \\
\text { - (TRACE) }\end{array}$ & A & Not ready \\
\hline
\end{tabular}


RELAP-7 Software Verification and Validation Plan: Requirements Traceability Matrix (RTM) Update and Code Verification Strategy

\begin{tabular}{|c|c|c|c|c|c|c|c|c|}
\hline VR-85 & val & Natural Circulation & 09/31/2016 & BWR & IET & $\begin{array}{l}\text { FIST program } \\
\text { - Natural circulation test 6PNC2 } \\
\text { - AURORA-B, ANP-10300 } \\
\text { (2009), ML100040158 } \\
\text { - NUREG/CR-2576, } \\
\text { NUREG/CR-4128 }\end{array}$ & A & Not ready \\
\hline VR-86 & val & Turbine Trip & 09/31/2016 & BWR & IET & $\begin{array}{l}\text { FIST program } \\
\text { - Turbine Trip test 4PTT1 } \\
\text { - AURORA-B, ANP-10300 } \\
\text { (2009), ML100040158 } \\
\text { - NUREG/CR-2576, } \\
\text { NUREG/CR-4128 }\end{array}$ & A & Not ready \\
\hline VR-87 & val & SLB & 09/31/2016 & BWR & IET & $\begin{array}{l}\text { FIST program } \\
\text { - Steam Line Break test 6MSB1 } \\
\text { - AURORA-B, ANP-10300 } \\
\text { (2009), ML100040158 } \\
\text { - NUREG/CR-2576, } \\
\text { NUREG/CR-4128 }\end{array}$ & A & Not ready \\
\hline VR-88 & val & $\begin{array}{c}\text { ATWS } \\
\text { (MSIV closure w/o HPCS) }\end{array}$ & 09/31/2016 & BWR & IET & $\begin{array}{l}\text { FIST program } \\
\text { - ATWS test 6PMC2 } \\
\text { - NUREG-1230 (Rev. 4) } \\
\text { - "Posttest data analysis of FIST } \\
\text { experimental TRAC-BD1/MOD1 } \\
\text { power transient experiment" } \\
\text { (Report No.: } E G G-M-\text {--18884) } \\
\text { - NUREG/CR-2576, } \\
\text { NUREG/CR-3711 }\end{array}$ & A & Not ready \\
\hline VR-89 & val & LBLOCA & 09/31/2016 & PWR & IET & $\begin{array}{l}\text { 1. LOFT (Loss of Fluid Test) } \\
\text { - Test L2-5 (ISP-13) (TRACE, } \\
\text { RELAP5, RELAP5-3D) } \\
\text { - Test LB-1 (TRACE) } \\
\text { - NUREG/IA-28 } \\
\text { 2. PKL facility } \\
\text { - Test K9 (ISP-10) } \\
\text { - CSNI Report No. } 64 \text { (1981) } \\
\text { 3. Achilles } \\
\text { - CSNI Report No. } 11 \text { (ISP-25) }\end{array}$ & A & Not ready \\
\hline
\end{tabular}


RELAP-7 Software Verification and Validation Plan: Requirements Traceability Matrix (RTM) Update and Code Verification Strategy

\begin{tabular}{|c|c|c|c|c|c|c|c|c|}
\hline VR-90 & val & SBLOCA & 09/31/2016 & PWR & IET & $\begin{array}{l}\text { 1. LOFT (Loss of Fluid Test) } \\
\text { - Test L3-1 (ISP-09) (TRACE) } \\
\text { - Test L3-2 (reference?) } \\
\text { - Test L3-5 (RCP running) } \\
\text { (NUREG/IA-0024) } \\
\text { - Test L3-6 (RCP tripped) (ISP- } \\
\text { 11) } \\
\text { - NUREG/CR-3005, 3214 } \\
\text { 2. ROSA-IV } \\
\text { - Test SB-CL-01 2.5\% CLB with } \\
\text { delayed ECCS (TRACE) } \\
\text { - Test SB-CL-05 5\% CLB with } \\
\text { ECCS and AFW (TRACE) } \\
\text { - Test SB-CL-08 5\% CLB with } \\
\text { no pump ECCS and no AFW } \\
\text { (reference?) } \\
\text { - Test SB-CL-09 10\% CLB with } \\
\text { ECCS (reference?) } \\
\text { - Test SB-CL-14 10\% CLB with } \\
\text { ECCS with LPI only (TRACE) } \\
\text { - Test SB-CL-15 0.5\% CLB with } \\
\text { no ECCS and no AFW (TRAACE) } \\
\text { - Test SB-CL-18 5\% CLB with } \\
\text { LPI only (TRACE, RELAP5, } \\
\text { REAL5-3D) } \\
\text { (NUREG/IA-0095, ISP-26, } \\
\text { CSNI (91)13) } \\
\text { - Test IB-CL-02 17\% CLB }\end{array}$ & $\mathrm{P} / \mathrm{A}$ & Not ready \\
\hline VR-91 & val & Loss of load & 09/31/2016 & PWR & IET & $\begin{array}{l}\text { 1. LOFT (Loss of Fluid Test) } \\
\text { - Test L6-1 } \\
\text { - NUREG/CR-1797 }\end{array}$ & A & Not ready \\
\hline VR-92 & val & RCP trip & 09/31/2016 & PWR & IET & $\begin{array}{l}\text { LOFT } \\
\text { - Test L6-2 } \\
\text { - NUREG/CR-1797 }\end{array}$ & A & Not ready \\
\hline VR-93 & val & Excessive load increase & 09/31/2016 & PWR & IET & $\begin{array}{l}\text { LOFT } \\
\text { - Test L6-3 } \\
\text { - NUREG/CR-1797 }\end{array}$ & A & Not ready \\
\hline
\end{tabular}


RELAP-7 Software Verification and Validation Plan: Requirements Traceability Matrix (RTM) Update and Code Verification Strategy

\begin{tabular}{|c|c|c|c|c|c|c|c|c|}
\hline VR-94 & val & $\begin{array}{c}\text { Overcooling } \\
\text { (Increase in secondary heat } \\
\text { removal) }\end{array}$ & 09/31/2016 & PWR & IET & $\begin{array}{l}\text { LOFT } \\
\text { - Tests L6-7, L9-2 } \\
\text { - NUREG/CR-2277 }\end{array}$ & A & Not ready \\
\hline VR-95 & val & $\begin{array}{c}\text { LOAF } \\
\text { with subsequent feed-and-bleed } \\
\text { operation }\end{array}$ & $09 / 31 / 2016$ & PWR & IET & $\begin{array}{l}\text { 1. LOFT } \\
\text { - Tests L9-1, L3-3 } \\
\text { - NUREG/IA-0114 } \\
\text { (RELAP5/MOD3) } \\
\text { - NUREG/IA-0228 } \\
\text { (RELAP5/MOD3.3) } \\
\text { 2. ROSA-IV program } \\
\text { - No publicly available data or } \\
\text { reference }\end{array}$ & $\mathrm{P} / \mathrm{A}$ & Not ready \\
\hline VR-96 & val & ATWS (LOFW) & 09/31/2016 & PWR & IET & $\begin{array}{l}\text { 1. LOFT } \\
\text { - Test L9-3 } \\
\text { - NUREG/IA-0192 } \\
\text { (RELAP5/Mod3.2.2) } \\
\text { - NSAC-78 } \\
\text { 2. ROSA-IV } \\
\text { - Test 3-2 } \\
\text { - NUREG/IA-0410 (RELAP5) }\end{array}$ & A & Not ready \\
\hline VR-97 & val & Turbine Trip & 09/31/2016 & PWR & IET & $\begin{array}{l}\text { ROSA-IV program } \\
\text { - No publicly available data or } \\
\text { reference }\end{array}$ & N/A & Not ready \\
\hline VR-98 & val & LOFW & 09/31/2016 & PWR & IET & $\begin{array}{l}\text { ROSA-IV program } \\
\text { - No publicly available data or } \\
\text { reference }\end{array}$ & N/A & Not ready \\
\hline
\end{tabular}


RELAP-7 Software Verification and Validation Plan: Requirements Traceability Matrix (RTM) Update and Code Verification Strategy

\begin{tabular}{|c|c|c|c|c|c|c|c|c|}
\hline VR-99 & val & $\begin{array}{l}\text { Natural circulation } \\
\text { (single-phase) }\end{array}$ & 09/31/2016 & PWR & IET & $\begin{array}{l}\text { 1. ROSA-IV program (single- } \\
\text { phase test) } \\
\text { - Test 1.1 (NUREG/IA-0419, } \\
\text { TRACE) } \\
\text { 2. SEMISCALE experiment } \\
\text { - S-NC-1, S-NC-10 (RELAP5- } \\
\text { 3D) } \\
\text { - S-NC-2 (RELAP5-3D, } \\
\text { TRACE) } \\
\text { 3. PACTEL natural circulation } \\
\text { experiment } \\
\text { - ISP-33 } \\
\text { 4. PANDA natural circulation tests } \\
\text { - ISP-42 (PCCS for ALWR is of } \\
\text { main interest.) } \\
\text { 5. PKL Exp. } \\
\text { - Test 1D1-4 (TRAC-PF1, } \\
\text { NUREG/CR-3280) }\end{array}$ & $\mathrm{P} / \mathrm{A}$ & Not ready \\
\hline VR-100 & val & $\begin{array}{l}\text { Natural circulation } \\
\text { (two-phase) }\end{array}$ & 09/31/2016 & PWR & IET & $\begin{array}{l}\text { 1. SEMISCALE natural circulation } \\
\text { tests (Mod-2A) } \\
\text { - S-NC-2, S-NC-3 (RELAP5-3D, } \\
\text { TRACE) } \\
\text { - S-NC-10 (RELAP5-3D) } \\
\text { 2. PACTEL natural circulation } \\
\text { experiment } \\
\text { - ISP-33 } \\
\text { 3. PANDA natural circulation tests } \\
\text { - ISP-42 (PCCS for ALWR is of } \\
\text { main interest.) } \\
\text { 4. PKL facility } \\
\text { - Tests PKL-B4.2, B4.3 } \\
\text { (NUREG/IA-0170) } \\
\text { - Tests PKL-1D1-9, 1D1-15 } \\
\text { (NUREG/CR-3280) } \\
\text { - CSNI Report No. } 10 \text { (1981) } \\
\text { (ISP-10) }\end{array}$ & N/A & Not ready \\
\hline VR-101 & val & SGTR & 09/31/2016 & PWR & IET & $\begin{array}{l}\text { 1. ROSA-IV } \\
\text { - Test SB-SG-06 } \\
\text { - NUREG/IA-0130 } \\
\text { 2. BETHSY tests 4.3b, 3.4b } \\
\text { (CATHARE-2) } \\
\text { 3. LOFT tests L6-8C-1, L6-8C-C2 } \\
\text { (CATHARE-2) }\end{array}$ & $\mathrm{P} / \mathrm{A}$ & Not ready \\
\hline
\end{tabular}


RELAP-7 Software Verification and Validation Plan: Requirements Traceability Matrix (RTM) Update and Code Verification Strategy

\begin{tabular}{|c|c|c|c|c|c|c|c|c|}
\hline VR-102 & val & Multiple SGTR & $09 / 31 / 2016$ & PWR & IET & $\begin{array}{l}\text { ROSA-IV program } \\
\text { - No publicly available data or } \\
\text { reference }\end{array}$ & N/A & Not ready \\
\hline VR-103 & val & SLB & $09 / 31 / 2016$ & PWR & IET & $\begin{array}{l}\text { 1. ROSA-IV } \\
\text { - Test SB-SL-01 (10\% MSLB) } \\
\text { - NUREG/IA-0148 } \\
\text { 2. Westinghouse Model Boiler-2 } \\
\text { test facility } \\
\text { - SLB tests } 100 \%, 50 \%, 8 \% \\
\text { (with SGTR) } \\
\text { - SLB Test T-2013 100\% break, } \\
\text { SLB 50\% break (AEEW-02476) } \\
\text { - NUREG/CR-3661, } \\
\text { NUREG/CR-4751 } \\
\text { - NUREG/IA-0106 } \\
\text { 3. LOBI facility } \\
\text { - Test BT12 (NUREG/IA-0079) }\end{array}$ & $\mathrm{P} / \mathrm{A}$ & Not ready \\
\hline VR-104 & val & SBO & $09 / 31 / 2016$ & PWR & IET & $\begin{array}{l}\text { ROSA-IV } \\
\text { - SBO tests w/ or w/o RCP seal } \\
\text { leak (No publicly available data or } \\
\text { reference) }\end{array}$ & N/A & Not ready \\
\hline VR-105 & val & $\begin{array}{l}\text { Reflood during LOCA } \\
\text { (Multi-D effects) }\end{array}$ & 09/31/2016 & PWR & IET & $\begin{array}{l}\text { 1. CCTF } \\
\text { - Tests C2-4, C2-5, C2-8, C-12 } \\
\text { (TRACE) } \\
\text { - Test C2-11 } \\
\text { - NUREG-1230, NUREG/IA- } \\
0127, \text { GRS-100 (ISBN: 3-923875- } \\
\text { 50-9) } \\
\text { 2. SCTF } \\
\text { - Tests S2-01 (Run 606), S2-02 } \\
\text { (Run 607), S2-06 (Run 611), S2- } \\
\text { 16 (Run 621), S2-17(Run 622) } \\
\text { (TRACE) } \\
\text { - Tests S2-SH1 (Run 604), S2- } \\
\text { SH2 (Run 605) (TRACE) } \\
\text { - Test S2-AC1 } \\
\text { - NUREG-1230 }\end{array}$ & $\mathrm{P} / \mathrm{A}$ & Not ready \\
\hline
\end{tabular}


RELAP-7 Software Verification and Validation Plan: Requirements Traceability Matrix (RTM) Update and Code Verification Strategy

\begin{tabular}{|c|c|c|c|c|c|c|c|c|}
\hline VR-106 & val & Loss of decay heat removal & 09/31/2016 & PWR & IET & $\begin{array}{l}\text { 1. ROSA-IV } \\
\text { - Four configurations were tested } \\
\text { for Loss of Decay Heat Removal } \\
\text { scenarios, each with three different } \\
\text { opening areas (NUREG/IA-0143) } \\
\text { (i. Loop intact, ii. Cold leg } \\
\text { opening (RCP maintenance), iii. } \\
\text { SG manway open, iv. Pressurizer } \\
\text { manway open) } \\
\text { 2. BETHSY } \\
\text { - Tests 6.9a, 6.9c (ISP-38) } \\
\text { - CSNI Report 2000(5), } \\
\text { NUREG/IA-0188, NUREG/IA- } \\
\text { 0187 } \\
\text { 3. PKL } \\
\text { - Tests E3.1, F2.2, F2.1 } \\
\text { - NUREG/IA-256, NUREG/IA- } \\
\text { 257 }\end{array}$ & A & Not ready \\
\hline VR-107 & val & Turbine Trip & 09/31/2016 & BWR & PT & $\begin{array}{l}\text { 1. Peach Bottom Unit } 2 \text { Turbine } \\
\text { Trip Tests } \\
\text { - NEA/NSC/2001-1, } \\
\text { NEA/NSC/2004-21, } \\
\text { NEA/NSC/2006-23, } \\
\text { NEA/NSC/2010-11 } \\
\text { - EPRI NP-563, EPRI NP-564, } \\
\text { RETRAN-3D (code manual Vol. } \\
\text { 4) } \\
\text { 2. Cofrentes NPP turbine trip } \\
\text { transient } \\
\text { - NUREG/IA-0120, RETRAN- } \\
\text { 3D } \\
\text { 3. Santa Maria De Garoña NPP } \\
\text { turbine trip transient } \\
\text { - NUREG/IA-0226 }\end{array}$ & A & Not ready \\
\hline VR-108 & val & BWR core stability & 09/31/2016 & BWR & PT & $\begin{array}{l}\text { Peach Bottom Unit } 2 \text { Stability } \\
\text { Tests } \\
\text { - EPRI NP-4498-Volume } 9 \\
\text { - RETRAN 3D (code manual } \\
\text { Vol 4) }\end{array}$ & $\mathrm{P} / \mathrm{A}$ & Not ready \\
\hline VR-109 & val & BWR start-up tests & 09/31/2016 & BWR & PT & $\begin{array}{l}\text { Grand Gulf Startup Transient Tests } \\
\text { (EPRI NP-6230) } \\
\text { - Test for loss of feedwater } \\
\text { heater (No publicly available data } \\
\text { or reference) } \\
\text { - Test for generator load } \\
\text { rejection from 100\% power (No } \\
\text { publicly available data or } \\
\text { reference) } \\
\text { - Test for recirculation pump trip }\end{array}$ & N/A & Not ready \\
\hline
\end{tabular}


RELAP-7 Software Verification and Validation Plan: Requirements Traceability Matrix (RTM) Update and Code Verification Strategy

\begin{tabular}{|c|c|c|c|c|c|c|c|c|}
\hline & & & & & & $\begin{array}{l}\text { (No publicly available data or } \\
\text { reference) } \\
\text { - Test for MSIV closure at 74\% } \\
\text { power and } 100 \% \text { flow (No } \\
\text { publicly available data or } \\
\text { reference) }\end{array}$ & & \\
\hline VR-110 & val & Recirculation pump trip & 09/31/2016 & BWR & PT & $\begin{array}{l}\text { 1. Santa Maria De Garoña NPP } \\
\text { - Single Recirculation Pump Trip } \\
\text { Transient (NUREG/IA-0193) } \\
\text { 2. BWR-5 } \\
\text { - One recirculation pump trip } \\
\text { (RETRAN-3D) }\end{array}$ & A & Not ready \\
\hline VR-111 & val & Feedwater Pump Trip & 09/31/2016 & BWR & PT & $\begin{array}{l}\text { Cofrentes NPP } \\
\text { - One Feedwater Pump Trip } \\
\text { Transient (NUREG/IA-0068) } \\
\text { - Feedwater pump trip } \\
\text { (RETRAN-3D) }\end{array}$ & A & Not ready \\
\hline VR-112 & val & MSIV closure & 09/31/2016 & BWR & PT & $\begin{array}{l}\text { 1. Laguna Verde NPP (RETRAN- } \\
\text { 3D) } \\
\text { 2. BWR-5 (RETRAN-3D) } \\
\text { - single MSIV closure } \\
\text { - closure of all MSIVs } \\
\text { 3. Santa Maria De Garoña NPP } \\
\text { - MSIV Full Closure } \\
\text { (NUREG/IA-0122) }\end{array}$ & A & Not ready \\
\hline VR-113 & val & Other BWR plant tests & 09/31/2016 & BWR & PT & $\begin{array}{l}\text { RETRAN-3D (code manual Vol. } \\
\text { 4) assessed its capability based on } \\
\text { the following test data from } \\
\text { various plants [EPRI } 3002003110 \\
\text { (2014)]: } \\
\text { 1. Cofrentes NPP } \\
\text { - feedwater control failure } \\
\text { - level setpoint change } \\
\text { - recirc. pump speed transfer } \\
\text { 2. BWR-5 } \\
\text { - pressure setpoint change } \\
\text { - level setpoint change } \\
\text { 3. Kashiwazaki-Kariwa reactor } \\
\text { internals pump trip }\end{array}$ & $\mathrm{P} / \mathrm{A}$ & Not ready \\
\hline
\end{tabular}


RELAP-7 Software Verification and Validation Plan: Requirements Traceability Matrix (RTM) Update and Code Verification Strategy

\begin{tabular}{|c|c|c|c|c|c|c|c|c|}
\hline VR-114 & val & Loss of load & $09 / 31 / 2016$ & PWR & PT & $\begin{array}{l}\text { DOEL-4 NPP } \\
\text { - Manual Loss of Load Test of } \\
\text { November 23, 1985 } \\
\text { - (NUREG/IA-0043) }\end{array}$ & A & Not ready \\
\hline VR-115 & val & PWR startup tests & $09 / 31 / 2016$ & PWR & PT & $\begin{array}{l}\text { 1. Arkansas Nuclear One - Unit } 2 \\
\text { - } 4 \text { transient tests } \\
\text { - Test for loss of primary flow } \\
\text { from } 80 \% \text { power } \\
\text { - Test for full-length control rod } \\
\text { drop from } 50 \% \text { power } \\
\text { - Test for part-length control rod } \\
\text { drop from } 50 \% \text { power } \\
\text { - Test for turbine trip from } 100 \% \\
\text { power } \\
\text { - EPRI NP-1707, EPRI NP-1708 } \\
\text { (Rev. } 1 \text { ), EPRI NP-1709, } \\
\text { ANL/LWR/NRC 83-1, EPRI NP- } \\
\text { 4260, EPRI NP-4263 } \\
\text { 2. DOEL 2 NPP } \\
\text { - Pressurizer spray tests } \\
\text { (NUREG/IA-0020) }\end{array}$ & $\mathrm{P} / \mathrm{A}$ & Not ready \\
\hline VR-116 & val & Turbine Trip & $09 / 31 / 2016$ & PWR & PT & $\begin{array}{l}\text { Arkansas Nuclear One - Unit } 2 \\
\text { - EGG-SAAM-6415 } \\
\text { Vandellos II NPP (NUREG/IA- } \\
0108 \text { ) }\end{array}$ & $\mathrm{P} / \mathrm{A}$ & Not ready \\
\hline VR-117 & val & Loss of Off-Site Power & $09 / 31 / 2016$ & PWR & PT & $\begin{array}{l}\text { 1. Arkansas Nuclear One - Unit } 2 \\
\text { - EGG-NTAP-6309 } \\
\text { 2. McGuire } 1 \text { nuclear station } \\
\text { - Loss of offsite power event } \\
\text { (RELAP5/MOD3, MLO03780723) } \\
\text { 3. Kori 1 NPP (RETRAN-3D, } \\
\text { NUREG/IA-0030) }\end{array}$ & $\mathrm{P} / \mathrm{A}$ & Not ready \\
\hline
\end{tabular}


RELAP-7 Software Verification and Validation Plan: Requirements Traceability Matrix (RTM) Update and Code Verification Strategy

\begin{tabular}{|c|c|c|c|c|c|c|c|c|}
\hline VR-118 & val & SGTR & 09/31/2016 & PWR & PT & $\begin{array}{l}\text { 1. Prairie Island Unit } 1 \\
\text { - No publicly available data or } \\
\text { reference } \\
\text { 2. R. E. Ginna NPP } \\
\text { - Ginna } 1 / 25 / 1982 \text { steam } \\
\text { generator tube rupture accident } \\
\text { (NUREG-0909) } \\
\text { 3. DOEL } 2 \text { NPP } \\
\text { - NUREG/IA-0008, ISP-20 } \\
\text { (CSNI report No. 154) }\end{array}$ & $\mathrm{P} / \mathrm{A}$ & Not ready \\
\hline VR-119 & val & Load rejection & 09/31/2016 & PWR & PT & $\begin{array}{l}\text { Comanche Peak Unit } 1 \\
\text { (RETRAN-3D) } \\
\text { Cofrentes NPP (RETRAN-3D) } \\
\text { Laguna Verde NPP (RETRAN- } \\
\text { 3D) } \\
\text { BWR-5 (load rejection with } \\
\text { bypass) (RETRAN-3D) } \\
\text { Kori } 4 \text { (RETRAN-3D) } \\
\text { Vandellos II NPP (NUREG/IA- } \\
\text { 0107, NUREG/IA-0109) } \\
\end{array}$ & A & Not ready \\
\hline VR-120 & val & Multiple failures & $09 / 31 / 2016$ & PWR & PT & Kori 2 NPP (RETRAN-3D) & A & Not ready \\
\hline VR-121 & val & SBO & 09/31/2016 & PWR & PT & $\begin{array}{l}\text { Asco NPP Blackout Transients } \\
\text { (NUREG/IA-0119) }\end{array}$ & A & Not ready \\
\hline VR-122 & val & Feedwater line isolation & 09/31/2016 & PWR & PT & $\begin{array}{l}\text { Ringhals } 4 \text { NPP (NUREG/IA- } \\
0038 \text { ) }\end{array}$ & A & Not ready \\
\hline VR-123 & val & $\begin{array}{c}\text { Steam Line Isolation Valve } \\
\text { Closure }\end{array}$ & 09/31/2016 & PWR & PT & $\begin{array}{l}\text { Ringhals } 2 \text { NPP (NUREG/IA- } \\
0041)\end{array}$ & A & Not ready \\
\hline VR-124 & val & $\mathrm{RCP}$ trip & 09/31/2016 & PWR & PT & $\begin{array}{l}\text { Almaraz I NPP (NUREG/IA- } \\
\text { 0233) } \\
\text { Vandellos II NPP (NUREG/IA- } \\
0243 \text { ) } \\
\end{array}$ & A & Not ready \\
\hline VR-125 & val & Reactor trip & 09/31/2016 & PWR & PT & $\begin{array}{l}\text { Tihange-2 NPP (NUREG/IA- } \\
\text { 0044) } \\
\text { DOEL } 4 \text { NPP (NUREG/IA-0051) }\end{array}$ & A & Not ready \\
\hline
\end{tabular}


RELAP-7 Software Verification and Validation Plan: Requirements Traceability Matrix (RTM) Update and Code Verification Strategy

\begin{tabular}{|c|c|c|c|c|c|c|c|c|}
\hline VR-126 & val & Natural circulation & $09 / 31 / 2016$ & PWR & PT & $\begin{array}{l}\text { - Borssele NPP (NUREG/IA- } \\
0091 \text { ) } \\
\text { - Yong-Gwang Unit } 2 \text { NPP } \\
\text { (NUREG/IA-0125) } \\
\text { - TMI unit 1 (natural circulation } \\
\text { test of 10/7/1985) (BAW- } \\
\text { 10193NP-A) } \\
\text { - KNU-1 loss of offsite power } \\
\text { (NUREG/IA-0030) }\end{array}$ & A & Not ready \\
\hline VR-127 & val & Load trip & 09/31/2016 & PWR & PT & $\begin{array}{l}\text { Yong-Gwang Unit } 2 \\
\text { - Net Load Trip Test Data } \\
\text { (NUREG/IA-0092) }\end{array}$ & A & Not ready \\
\hline VR-128 & val & Other PWR plant tests & 09/31/2016 & PWR & PT & $\begin{array}{l}\text { 1. Kori Unit } 3 \\
\text { - Inadvertent Safety Injection } \\
\text { Incident (NUREG/IA-0105) } \\
\text { 2. Vandellos II } \\
\text { - Main Feedwater Turbopump } \\
\text { Trip (NUREG/IA-0110) } \\
\text { 3. Asco NPP } \\
\text { - Pressurizer Spray Valve Faulty } \\
\text { Opening Transient (NUREG/IA- } \\
\text { 0121) } \\
\text { 4. Jose Cabrera Nuclear Station } \\
\text { - Pressurizer Spray Valve } \\
\text { Inadverted Fully Opening } \\
\text { Transient and Recovery by Natural } \\
\text { Circulation (NUREG/IA-0124) } \\
\text { 5. Maanshan PWR NPP Transient } \\
\text { Data (NUREG/IA-0241) }\end{array}$ & A & Not ready \\
\hline VR-129 & val & MSIV closure & $09 / 31 / 2016$ & PWR & PT & $\begin{array}{l}\text { Vandellos-II NPP (NUREG/IA- } \\
\text { 0197) }\end{array}$ & A & Not ready \\
\hline VR-130 & val & Loss of decay heat removal & $09 / 31 / 2016$ & PWR & PT & $\begin{array}{l}\text { 1. Vogtle Unit } 1 \text { (NUREG-1410) } \\
\text { 2. Diablo Canyon Unit } 2 \\
\text { (NUREG-1269) }\end{array}$ & A & Not ready \\
\hline VR-131 & val & Turbine Trip & $09 / 31 / 2016$ & $\begin{array}{l}\text { PWR } \\
(\mathrm{B} \& W)\end{array}$ & PT & $\begin{array}{l}\text { Oconee Unit } 3 \\
\text { - Oconee Unit } 3 \text { turbine trip with } \\
\text { feedwater overfeed transient of } \\
3 / 14 / 1980 \text { (No publicly available } \\
\text { data or reference) }\end{array}$ & N/A & Not ready \\
\hline
\end{tabular}


RELAP-7 Software Verification and Validation Plan: Requirements Traceability Matrix (RTM) Update and Code Verification Strategy

\begin{tabular}{|c|c|c|c|c|c|c|c|c|}
\hline VR-132 & val & SBLOCA & $09 / 31 / 2016$ & $\begin{array}{l}\text { PWR } \\
(\mathrm{B} \& W)\end{array}$ & PT & $\begin{array}{l}\text { TMI-2 Accident } \\
\text { - No publicly available data or } \\
\text { reference }\end{array}$ & N/A & Not ready \\
\hline VR-133 & val & Stuck-open PORV transient & $09 / 31 / 2016$ & $\begin{array}{l}\text { PWR } \\
(\mathrm{B} \& W)\end{array}$ & PT & $\begin{array}{l}\text { Crystal River-3 NPP } \\
\text { - Crystal River Unit } 3 \text { stuck-open } \\
\text { PORV transient of 2/26/1980 } \\
\text { (NUREG/CR-3646, NSAC-3 } \\
\text { (1980), NSAC-15 (1981) } \\
\text { - No publicly available data or } \\
\text { reference }\end{array}$ & N/A & Not ready \\
\hline VR-134 & val & Loss of Off-Site Power & $09 / 31 / 2016$ & $\begin{array}{c}\text { PWR } \\
(\mathrm{B} \& W)\end{array}$ & PT & $\begin{array}{l}\text { Arkansas Nuclear One - Unit } 1 \\
\text { - EGG-SAAM-6381 }\end{array}$ & N/A & Not ready \\
\hline VR-135 & val & LOAF & $09 / 31 / 2016$ & $\begin{array}{l}\text { PWR } \\
(\mathrm{B} \& W)\end{array}$ & PT & $\begin{array}{l}\text { Davis-Besse NPP } \\
\text { - Davis-Besse loss of all } \\
\text { feedwater event of 6/9/1985 } \\
\text { (NUREG-1154, MAAP Code } \\
\text { Manual Vol. 3, NUREG/CR-4946) } \\
\text { - No publicly available data or } \\
\text { reference }\end{array}$ & N/A & Not ready \\
\hline VR-136 & val & Loss of ICS & 09/31/2016 & $\begin{array}{l}\text { PWR } \\
(\mathrm{B} \& W)\end{array}$ & PT & $\begin{array}{l}\text { Rancho-Seco NPP } \\
\text { - Rancho-Seco loss of integrated } \\
\text { control system (ICS) power event } \\
\text { of } 12 / 26 / 1985 \text { (BAW-10193NP-A) }\end{array}$ & N/A & Not ready \\
\hline VR-137 & val & RCP trip & $09 / 31 / 2016$ & $\begin{array}{c}\text { PWR } \\
(\mathrm{B} \& W)\end{array}$ & PT & $\begin{array}{l}\text { Oconee Unit } 1 \text { and Crystal River } \\
\text { Unit } 3 \\
\text { - Trip of all RCP tests (BAW- } \\
\text { 10193NP-A) } \\
\text { - No publicly available data or } \\
\text { reference }\end{array}$ & N/A & Not ready \\
\hline VR-138 & val & $\begin{array}{c}\text { Vessel Mixing } \\
\text { (Multi-D TH effects) }\end{array}$ & 09/31/2016 & $\begin{array}{c}\text { PWR } \\
(\mathrm{B} \& W)\end{array}$ & PT & $\begin{array}{l}\text { Oconee B\&W PWR } \\
\text { - Testing of thermal mixing in } \\
\text { the lower plenum and core at } \\
\text { Oconee Unit } 1 \\
\text { - EPRI NP-3545, EPRI NP-3780 } \\
\text { - No publicly available data or } \\
\text { reference }\end{array}$ & N/A & Not ready \\
\hline
\end{tabular}

